\title{
Technology Assessment of a Fuel Cell Vehicle: 2017 Toyota Mirai
}

Energy Systems Division 


\section{About Argonne National Laboratory}

Argonne is a U.S. Department of Energy laboratory managed by UChicago Argonne, LLC under contract DE-AC02-06CH11357. The Laboratory's main facility is outside Chicago, at 9700 South Cass Avenue, Argonne, Illinois 60439. For information about Argonne and its pioneering science and technology programs, see www.anl.gov.

\section{DOCUMENT AVAILABILITY}

Online Access: U.S. Department of Energy (DOE) reports produced after 1991 and a growing number of pre-1991 documents are available free at OSTI.GOV (http://www.osti.gov/), a service of the US Dept. of Energy's Office of Scientific and Technical Information.

Reports not in digital format may be purchased by the public from the National Technical Information Service (NTIS):

U.S. Department of Commerce

National Technical Information Service

5301 Shawnee Rd

Alexandria, VA 22312

www.ntis.gov

Phone: (800) 553-NTIS (6847) or (703) 605-6000

Fax: (703) 605-6900

Email: orders@ntis.gov

Reports not in digital format are available to DOE and DOE contractors from the Office of Scientific and Technical Information (OSTI):

U.S. Department of Energy

Office of Scientific and Technical Information

P.O. Box 62

Oak Ridge, TN 37831-0062

www.osti.gov

Phone: (865) 576-8401

Fax: (865) 576-5728

Email: reports@osti.gov 


\section{Technology Assessment of a Fuel Cell Vehicle: 2017 Toyota Mirai}

prepared by

Henning Lohse-Busch, Michael Duoba, Kevin Stutenberg, Simeon Iliev, Mike Kern Energy Systems Division, Argonne National Laboratory

Brad Richards, Martha Christenson, Transport Canada

Arron Loiselle-Lapointe,

Environment and Climate Change Canada

Prepared for U.S. Department of Energy, Fuel Cell Technologies Office

June 2018 
TECHNOLOGY ASSESSMENT OF A FUEL CELL VEHICLE: 2017 TOYOTA MIRAI

HENNING LOHSE-BUSCH, MICHAEL DUOBA, KEVIN STUTENBERG, SIMEON ILIEV, MIKE KERN

Argonne National Laboratory

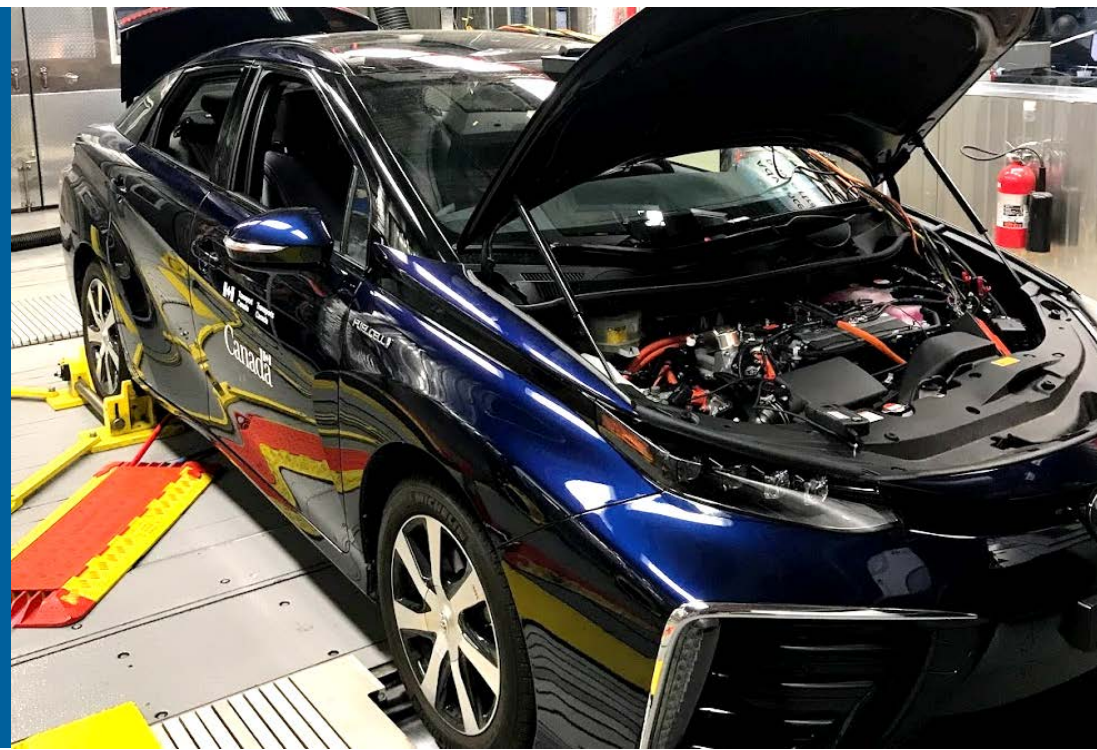

BRAD RICHARDS, MARTHA CHRISTENSON Transport Canada AARON LOISELLE-LAPOINTE Environment and Climate Change Canada

Report ANL/ESD-18/12

June 2018 (v10)

Argonne National Laboratory, IL 


\section{GOALS OF THE TESTING}

Testing of a fuel cell production vehicle in a controlled laboratory environment

The technical objectives* of the technology assessment of this advanced production vehicle are to:

- Establish vehicle level energy consumption, efficiency, and performance data on varying drive cycles at ambient temperatures ranging from $20 \mathrm{~F}$ to $95 \mathrm{~F}$ with a stretch goal of testing a cold start at OF.

- Measure the performance envelops and synergies between the fuel cell system and the hybrid system (incl. fuel cell system idle).

- Generate an efficiency map of the fuel cell systems.

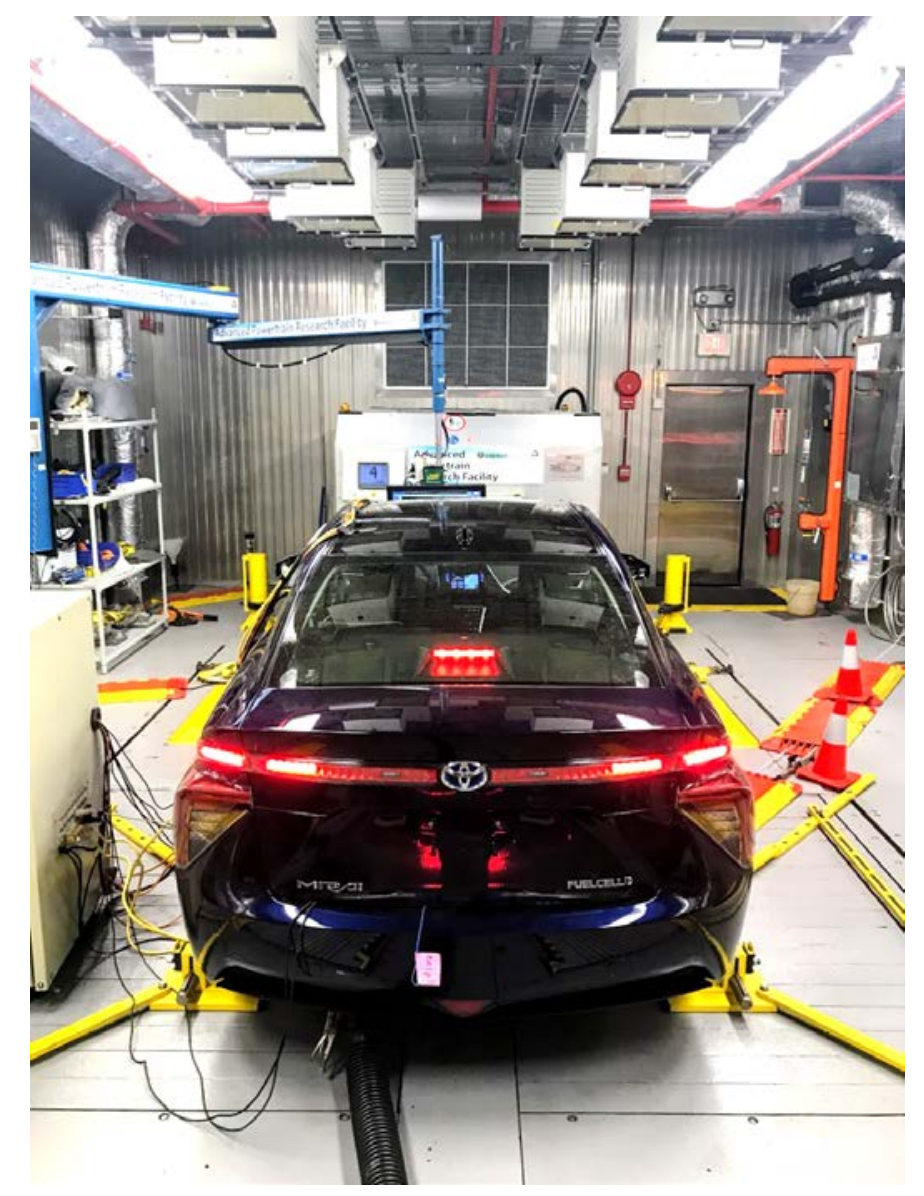




\section{OVERVIEW}

\section{Testing of a fuel cell production vehicle in a controlled laboratory environment in order to generate public powertrain data}

Vehicle overview and instrumentation

Fuel cell hybrid powertrain operation overview

- On cycles

- By components

Fuel cell stack and system efficiency (steady load mapping)

Certification drive cycle testing and results at $72 \mathrm{~F}$

- Results with average efficiencies

- Energy analysis

Fuel cell system operation

- Air \& hydrogen as function of power output

- FC idle testing

- FC maximum power output (continuous and peak pulses)

Impact of temperatures: $0 \mathrm{~F}, 20 \mathrm{~F}, 72 \mathrm{~F}$ and $95 \mathrm{~F}+850 \mathrm{~W} / \mathrm{m}^{2} \quad$ Link

- Fuel economy results and energy analysis ults for UDDS, Highway and US06 across temperatures

- Fuel cell system shut down from 72F to OF

- Fuel cell system cold start from 72F to OF

- Power delivery of FC conditioned at OF

- Hill climb test' at 95F with solar load

Summary and take away points
Link

Link

$\underline{\text { Link }}$

Link

Link

$\underline{\text { Link }}$

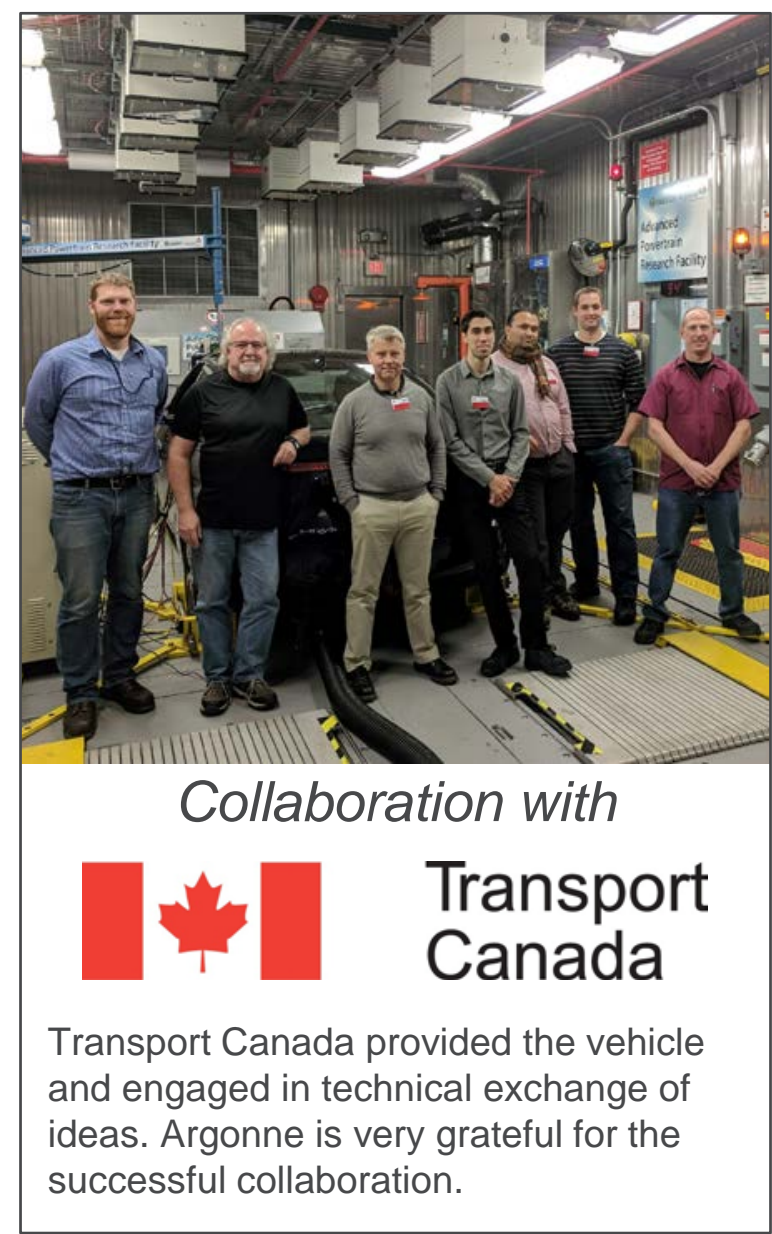

Abbreviations used in the presentation:

$\mathrm{FC} \rightarrow$ Fuel Cell

$\mathrm{HEV} \rightarrow$ Hybrid Electric Vehicle $\mathrm{BEV} \rightarrow$ Battery Electric Vehicle Mpge $\rightarrow$ Miles per gallon gasoline equivalent

Le/100km $\rightarrow$ Liter gasoline equivalent per 100 kilometers 


\section{ARGONNE VEHICLE TECHNOLOGY ASSESSMENT AND ANALYSIS REPORTING}
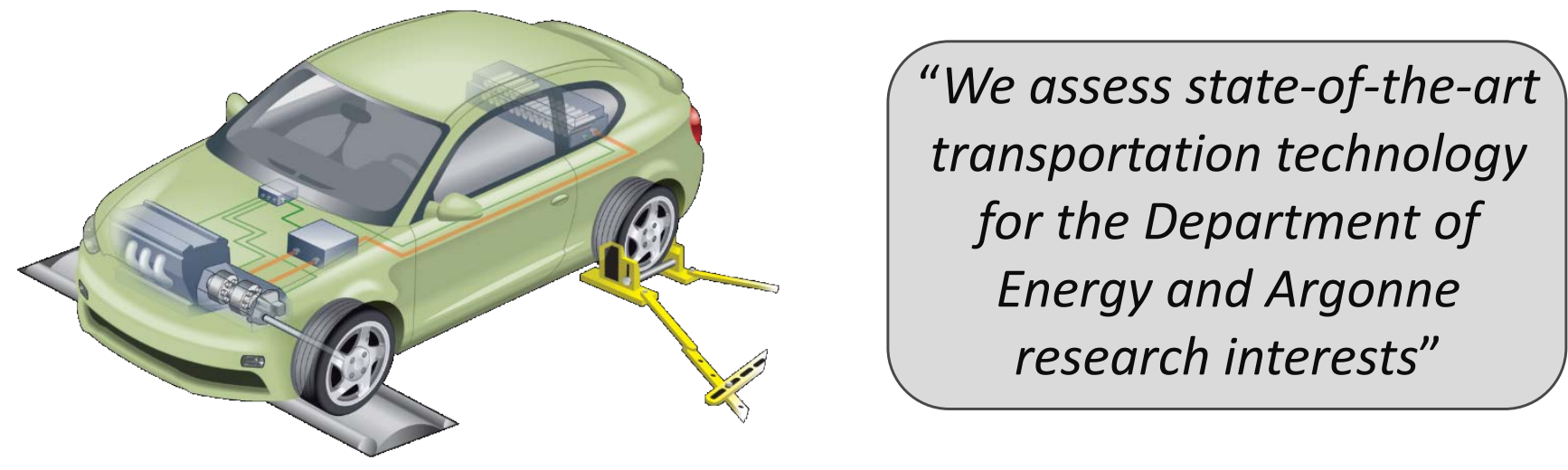

U.S. DEPARTMENT OF ENERCY
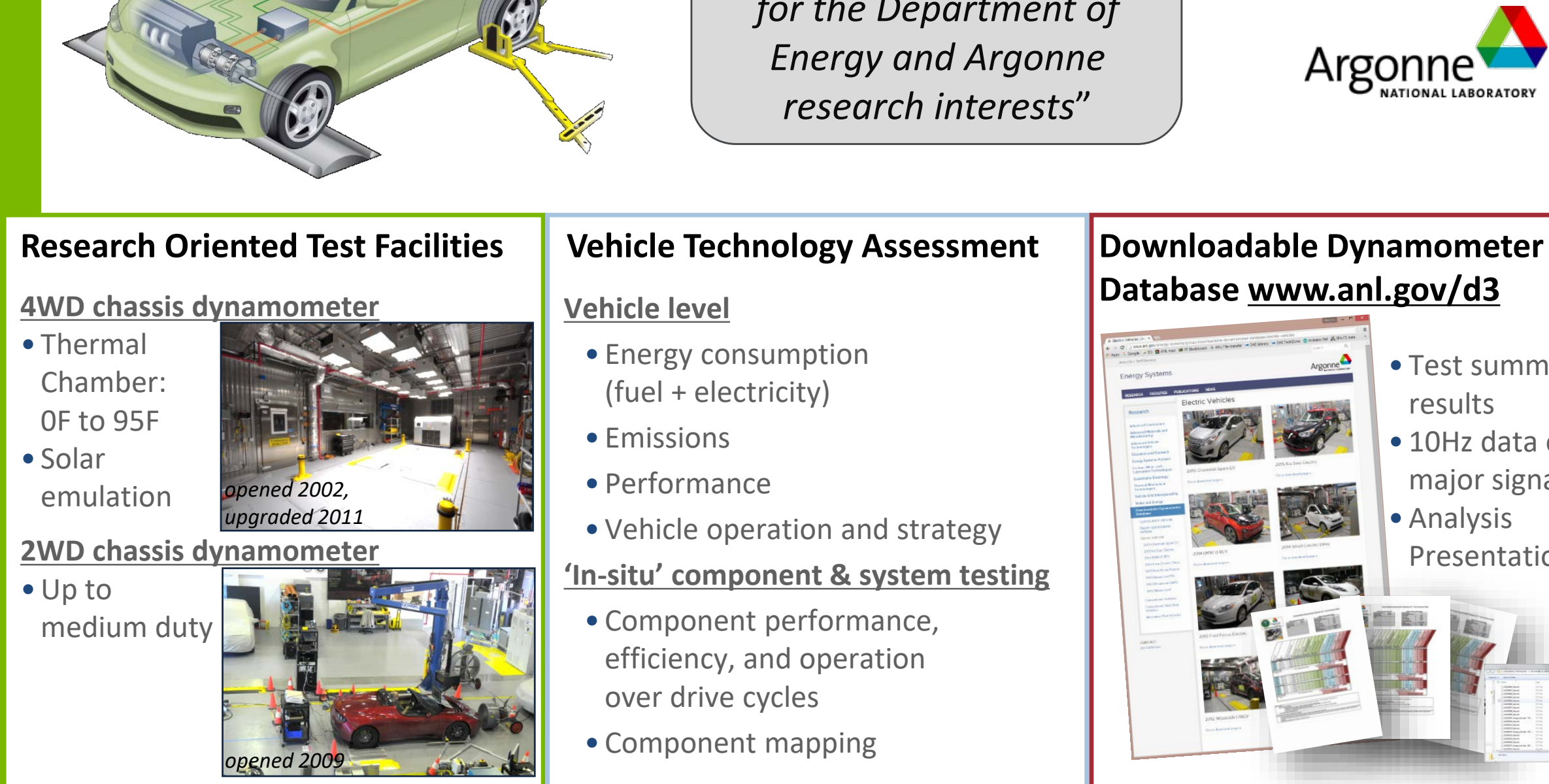

\section{Vehicle Technology Assessment}

Vehicle level

- Energy consumption

(fuel + electricity)

- Emissions

- Performance

- Vehicle operation and strategy

'In-situ' component \& system testing

- Component performance, efficiency, and operation over drive cycles

- Component mapping

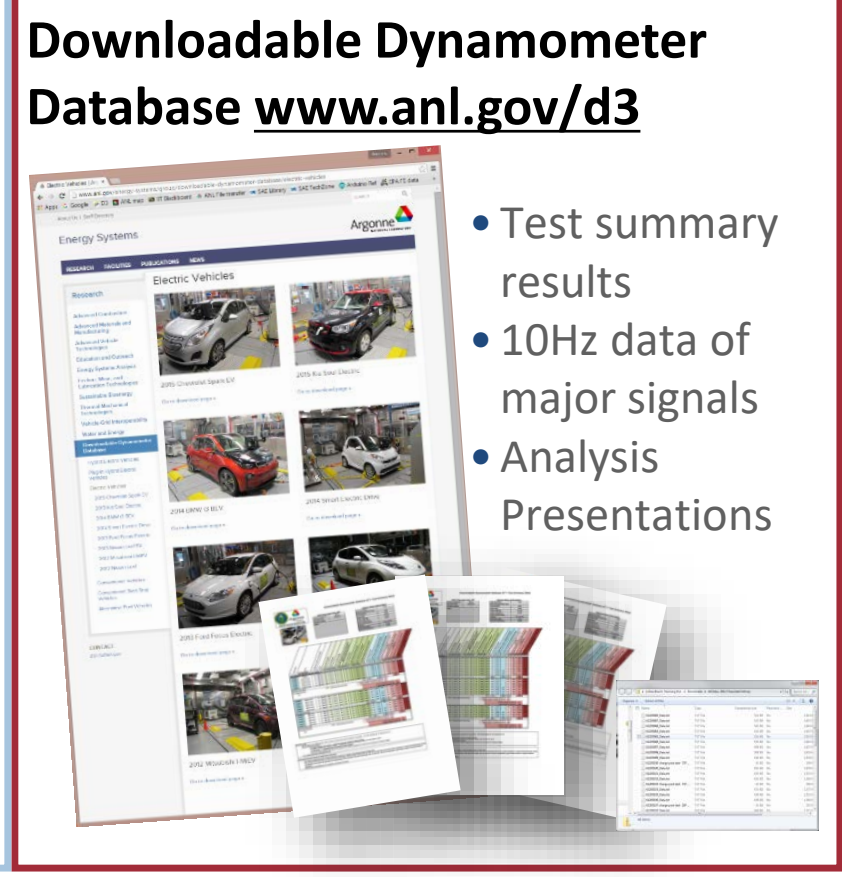

Argonne $\mathbf{A}$ 


\section{TOYOTA MIRAI FUEL CELL VEHICLE}

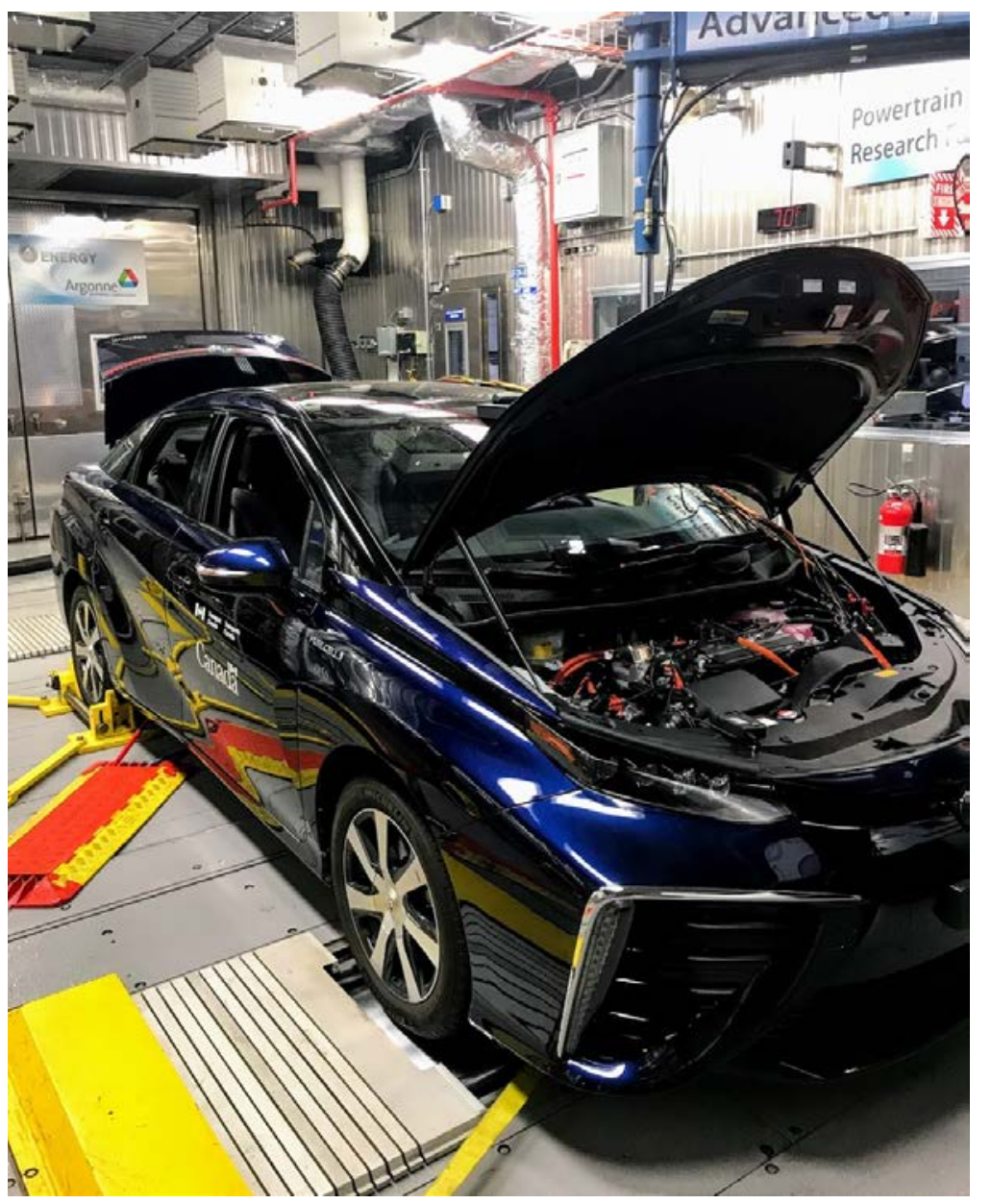

Transport Canada

\section{Toyota Mirai Fuel Cell Vehicle}

\begin{tabular}{|c|c|}
\hline Vehicle architecture & Fuel Cell Series Hybrid Vehicle \\
\hline Test weight & $4250 \mathrm{lbs}$ \\
\hline Power plant & $\begin{array}{l}\text { Fuel Cell } \\
\text { Solid Polymer Electrolyte Fuel Cell* } \\
370 \text { cells in stack } \\
114 \mathrm{~kW}^{*}, 3.1 \mathrm{~kW} / \mathrm{L}, 2.0 \mathrm{~kW} / \mathrm{kg} \\
\text { Flow channel: 3D fine-mesh flow field } \\
\text { (cathode) } \\
\text { Humidification: Internal circulation system } \\
\text { (humidifier-less) }\end{array}$ \\
\hline Hydrogen storage & 10,000 psi, $5 \mathrm{~kg}$ of $\mathrm{H} 2$ \\
\hline Battery & Nickel-metal Hydride, 1.6 kWh, 245V * \\
\hline Climate control & $\begin{array}{l}\text { Electrical AC compressor } \\
\text { Electric heater }\end{array}$ \\
\hline $\begin{array}{l}\text { EPA Label Fuel } \\
\text { Economy (mpge) }\end{array}$ & 66 City /66 Hwy /66 Combined ${ }^{+}$ \\
\hline Performance & Reported 0-60 Time: 9.0s^ \\
\hline
\end{tabular}

*Manufacturer data

+www.fueleconomy.gov

$\wedge$ www.zeroto60times.com 


\section{TOYOTA MIRAI POWERTRAIN COMPONENT LAYOUT}
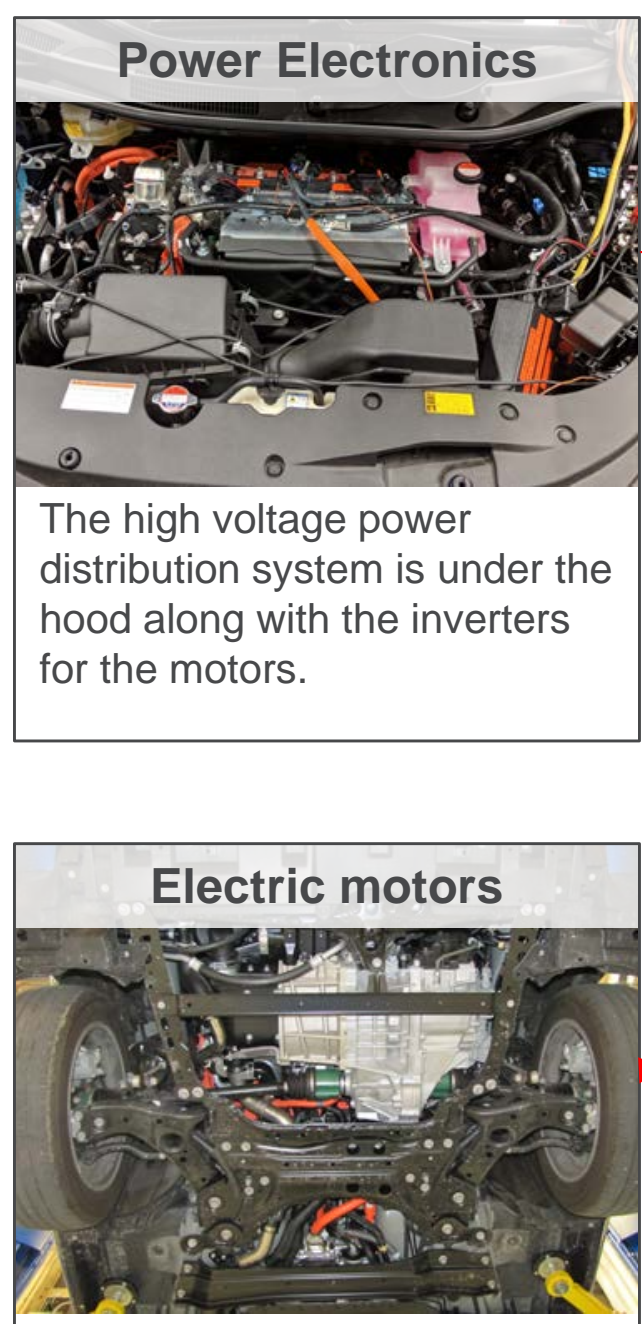

The electric drive motor and the air compressor are packaged in-line between the front wheels.

https://youtu.be/qofykBQre5o

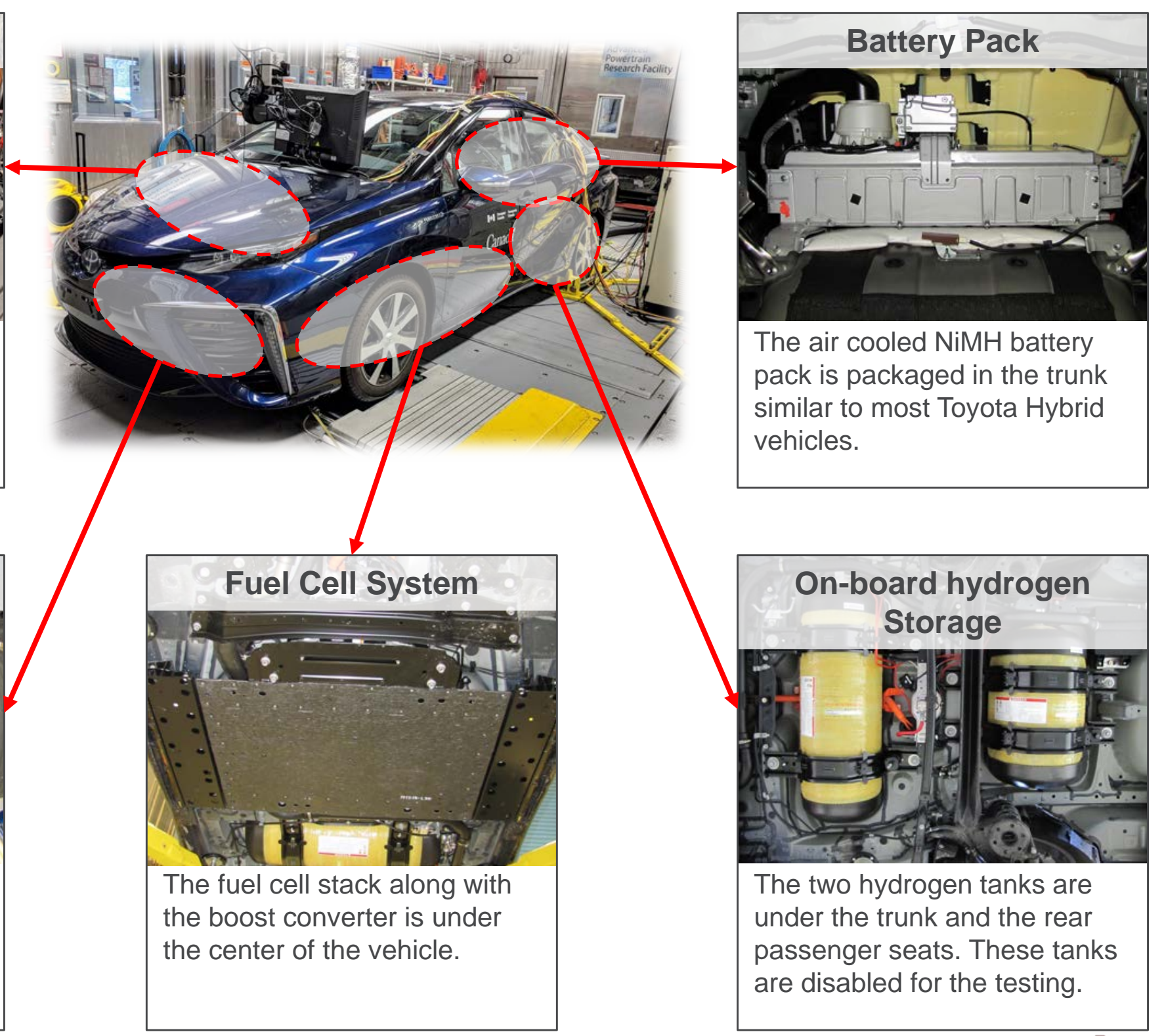

Argonne $\mathbf{A}$ 


\section{HYDROGEN MEASUREMENT FOR THE MIRAI}

Note: The $30 \mathrm{ft}$ delivery hose and the vehicle piping between the mass flow meters and the fuel cell stack creates a filtering effect and time delay on the fuel flow measurement.

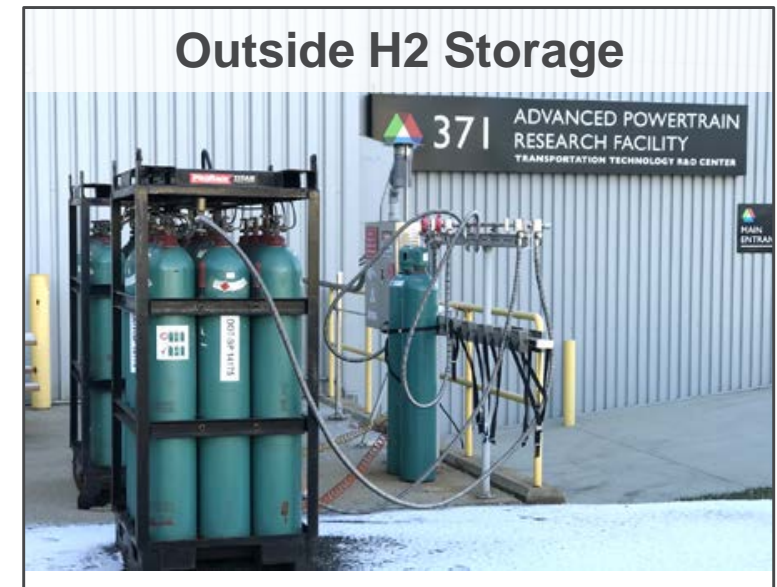

Laboratory grade hydrogen (99.999\% pure) in 12 packs with is equivalent to 6 gallons of gasoline. Hydrogen is piped into the building at 245 psi.

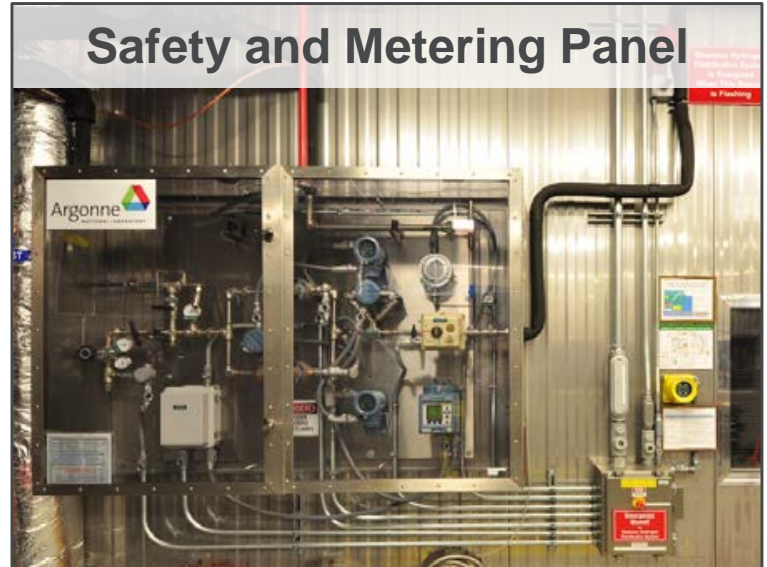

The hydrogen is metered by two Micro Motion $₫$ ELITE $®$ Coriolis mass flow meters. The panel has over pressure safeties, automatic shut-off valves, hydrogen sensors and a venting system. Any hydrogen sensor can trigger the active test cell safeties and alert the fire department.

\section{Different metering technics:}

Integrated mass flow meter $\rightarrow$ Yes

Ideal gas law $\rightarrow$ Possible but more complicated and not

Gravimetric $\rightarrow$ No too expensive for the

budget of this work

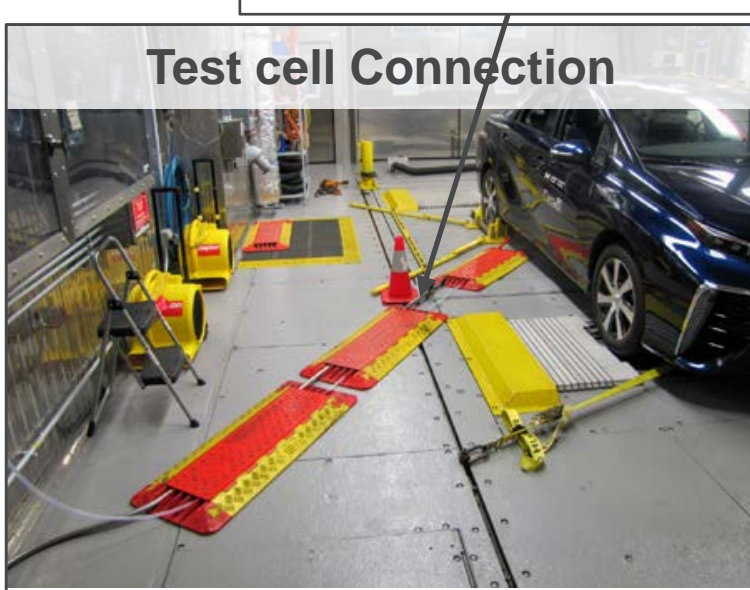

The vehicle hydrogen tanks are disabled and completely bypassed. The hydrogen is stepped down at the exit of the panel to 220 psi and fed into the pressure regulator in the middle of the vehicle.

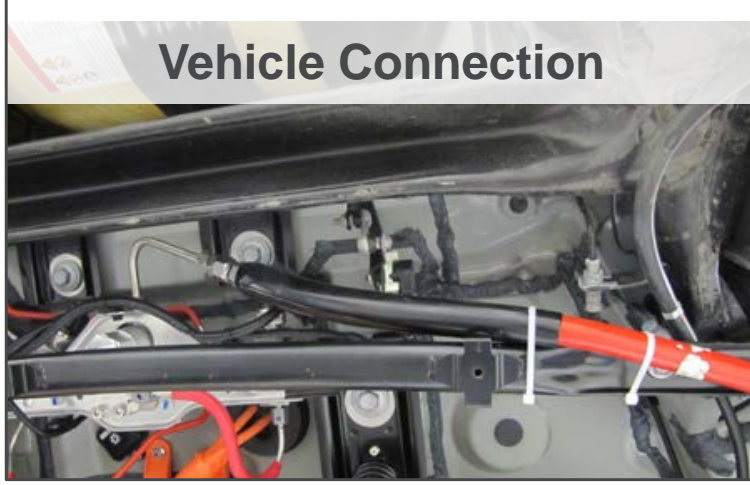

Argonne $\mathbf{A}$ 


\section{POWER MEASUREMENTS EQUIPMENT}

\section{Hydrogen Flow:}

Micro Motion $®$ ELITE $®$ Coriolis meters

- Argonne's uses the CMF010M and CMF025M.

- $\pm 0.25 \%$ gas flow accuracy; 0.0002 g/cc density accuracy

- The output of the meters is 4-20mA. The output on both meters is scaled from 4$20 \mathrm{~mA}$ to $0-3 \mathrm{gr} / \mathrm{sec}$ in the data acquisition system

- Further specifications: http://www.emerson.com/enus/catalog/micro-motion-elite-coriolis

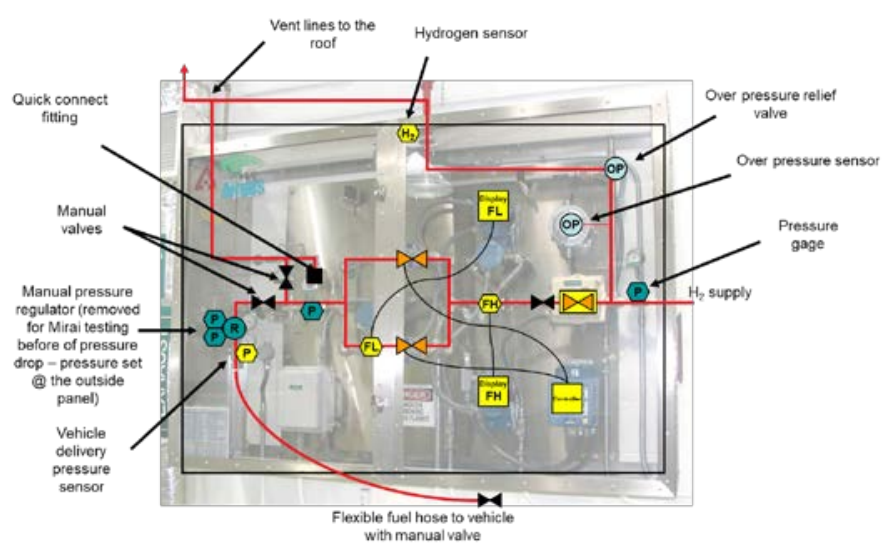

\section{Electric Power Flow:}

Hioki ${ }^{\circledR}$ High Precision Power Analyzer

- Hioki® Power Analyzers PW3390-10

- Hioki current clamps: CT6841, CT6843

- $\pm 0.1 \%$ power accuracy

- Outputs (V, I, P, IH, WH) transferred to DAQ via ethernet. $\mathrm{V}$, I transfer via analog signal in additional to ethernet.

- Further Specifications: https://www.hioki.com/en/products/detail/? product key $=6413$

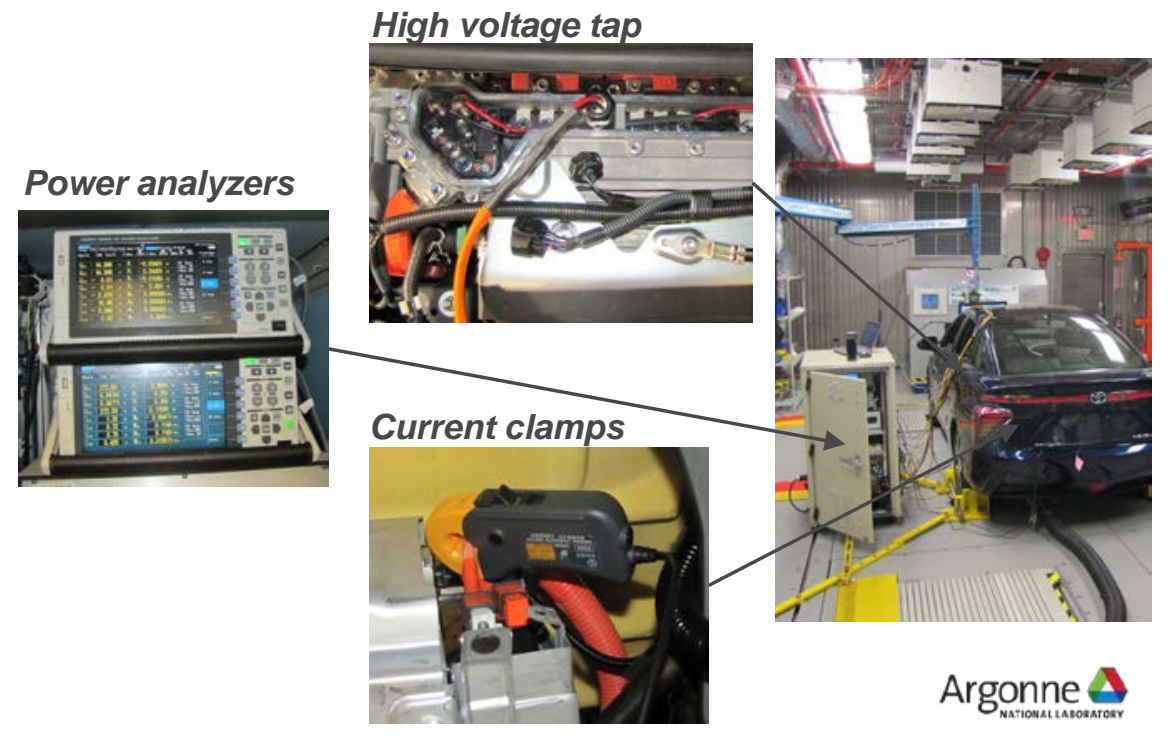




\section{SAMPLE OF HIGHLIGHTED CAN MESSAGES (TOTAL 400+)}

\begin{tabular}{|c|c|c|}
\hline Possible Vehicle Communication Signal & Value & Unit \\
\hline FC Voltage before Boosting & 239.1 & $\mathrm{~V}$ \\
\hline FC Voltage after Boosting & 345.5 & $\mathrm{~V}$ \\
\hline FC Current & 2.9 & A \\
\hline Target FC Output Power & 4.7 & $\mathrm{~kW}$ \\
\hline FC output Power & 0.94 & KW \\
\hline FC Stack Air Temperature (FC Stack Inlet) & 38 & $\mathrm{C}$ \\
\hline FC Stack. Air Pressure (FC Stack Inlet) & -0.91 & $\mathrm{kPa}$ (gauge) \\
\hline Intake Air Temperature & 26 & C \\
\hline Mass Air Flow Value & 300.9 & $\mathrm{NL} / \mathrm{min}$ \\
\hline Air Compressor Revolution & 639.5 & rpm \\
\hline Air Compressor Consumption Power & 0 & $\mathrm{~W}$ \\
\hline FC Stack Coolant Temperature (Radiator Outlet) & 29 & C \\
\hline FC Stack Coolant Temperature (FC Stack Outlet) & 45 & C \\
\hline FC Water Pump Revolution & 735.25 & rpm \\
\hline FC Water Pump Consumption Power & 19 & $\mathrm{~V}$ \\
\hline Radiator Fan 1 Driving Request & 0 & $\%$ \\
\hline Radiator Fan 2 Driving Request & 0 & $\%$ \\
\hline Estimated Radiator Rotary 'Valve Position & 0 & $\%$ \\
\hline FC Stack Air Temperature (FC Stack Inlet) & 38 & C \\
\hline FC Stack Air Pressure (FC Stack Inlet) & -1.35 & $\mathrm{kPa}$ (gauge) \\
\hline Mass Air Flow Value & 299.7 & $\mathrm{NL} / \mathrm{min}$ \\
\hline Hydrogen Pump Revolution & 607.35 & rpm \\
\hline Hydrogen Pump Consumption Power & 19 & $\mathrm{~W}$ \\
\hline Smoothed Value of Low-range Hydrogen Pressure & 54.5 & $\mathrm{kPa}$ (gauge) \\
\hline Hydrogen Injector Injection Number & 1 & \\
\hline FC Voltage before Boosting & 293.9 & \\
\hline FC Current & 3.35 & \\
\hline FC Mode & FC Working & \\
\hline Low Temperature Mode & 2 & \\
\hline FC Stack Power Generation Mode & Intermittent & \\
\hline FC Stack Cell Average Minimum Voltage & 0.02 & $\mathrm{~V}$ \\
\hline FC Stack Cell Minimum Voltage & 0 & $\mathrm{~V}$ \\
\hline FC Stack Cell Minimum Average Voltage Cell Channel No & 31 & ch \\
\hline FC Stack Cell Minimum Voltage Cell Channel No & 1 & ch \\
\hline FC Total Voltage & 293.9 & \\
\hline FC Stack Internal Resistance & 0.11 & ohm \\
\hline Hydrogen Pump Motor Temperature & 38 & ch \\
\hline Hydrogen Injector I Injection Request & Off & \\
\hline Hydrogen Injector 2 Injection Request & Off & \\
\hline Hydrogen Injector 3 Injection Request & Off & \\
\hline
\end{tabular}

\begin{tabular}{|c|c|c|}
\hline Exhaust Drainage Valve Driving Request & Off & \\
\hline \begin{tabular}{|l} 
Low-range Hydrogen Pressure \\
\end{tabular} & 29.07 & $\mathrm{kPa}$ (gauge) \\
\hline \begin{tabular}{|l} 
Internal Resistance ROB \\
\end{tabular} & 0.019 & ohm \\
\hline Internal Resistance RI17 & 0.019 & ohm \\
\hline Battery Pack Current Value (1B Correction) & -1.97 & A \\
\hline Delta SOC & & $\%$ \\
\hline SOCIG-ON & 64 & $\%$ \\
\hline Status of Charge Min & 45.5 & $\%$ \\
\hline Cooling Fan Mode 1 & 0 & \\
\hline Drive Motor Revolution & 0 & $\mathrm{rpm}$ \\
\hline Drive Motor Execution Torque & -0.5 & N.m \\
\hline \begin{tabular}{|l} 
Inverter Water Pump Revolution \\
\end{tabular} & 3500 & $\mathrm{rpm}$ \\
\hline DC/DC Converter target Pulse Duty & 79.3 & $\%$ \\
\hline Inverter Water Pump Run Control Duty & 10 & $\%$ \\
\hline Boost Ratio & 31.5 & $\%$ \\
\hline Boosting Converter Carrier Frequency & 9.55 & $\mathrm{kHz}$ \\
\hline A/C Consumption Power & 0 & W \\
\hline H2O Switch & OFF & \\
\hline Battery Charging Request & Off & \\
\hline FC Startup Request & Off & \\
\hline FC Stop Request & Off & \\
\hline FC Converter Available Output Current & 500 & $A$ \\
\hline Heater Temperature & 21.87 & $\bar{C}$ \\
\hline Water Heater Drive Status & Off & \\
\hline FC Converter Input Voltage & 297.2 & $\mathrm{~V}$ \\
\hline FC Converter Output Voltage & 346.6 & V \\
\hline FC Current & & $A$ \\
\hline FC Converter Shutdown Request & Off & \\
\hline FC Converter Request Power & 26.04 & $\mathrm{~kW}$ \\
\hline FC Air Compressor Motor Temperature & 29 & C \\
\hline FC Air Compressor Motor Temperature after IG-ON & 21 & $C$ \\
\hline Max FC Air Compressor Motor Temperature & 29 & $C$ \\
\hline FC Air Compressor Revolution & 638 & $\mathrm{rpm}$ \\
\hline Target FC Air Compressor Motor Torque & 0.7 & N.m \\
\hline FC Air Compressor Motor Torque & 0.6 & N.m \\
\hline Accel Pedal Position No. 1 & 15.68 & $\%$ \\
\hline Auxiliary Battery Voltage & 14.12 & V \\
\hline Motor Cooler Oil Pump Status & 0 & $\%$ \\
\hline Target Motor Cooler Oil Pump Duty & 10 & $\%$ \\
\hline H2O Indicator & Off & \\
\hline Water Heater Duty & 0 & $\%$ \\
\hline
\end{tabular}




\section{AIR COMPRESSOR POWER CALCULATIONS}

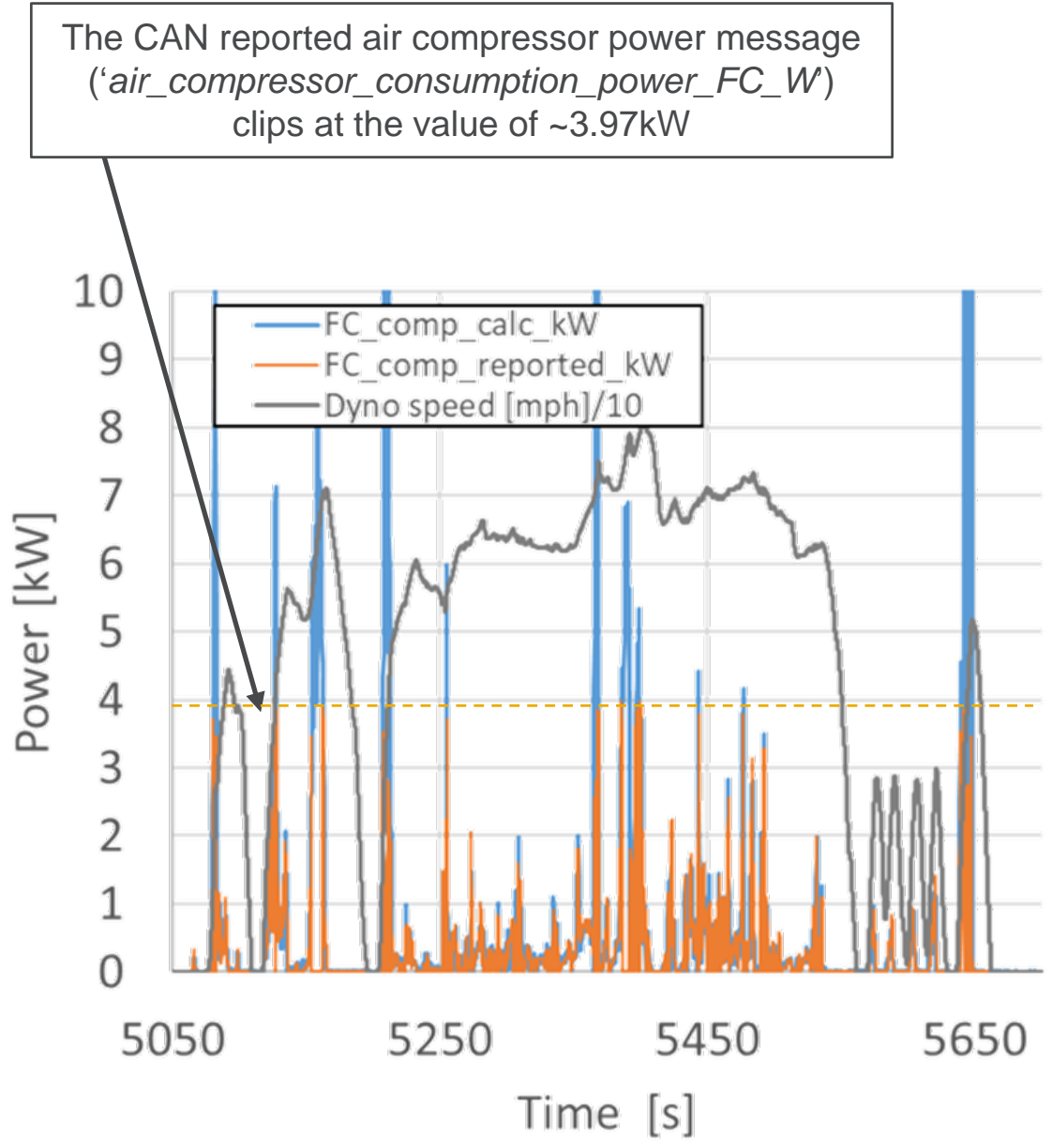

Air compressor power in the remainder of the analysis is the calculated power

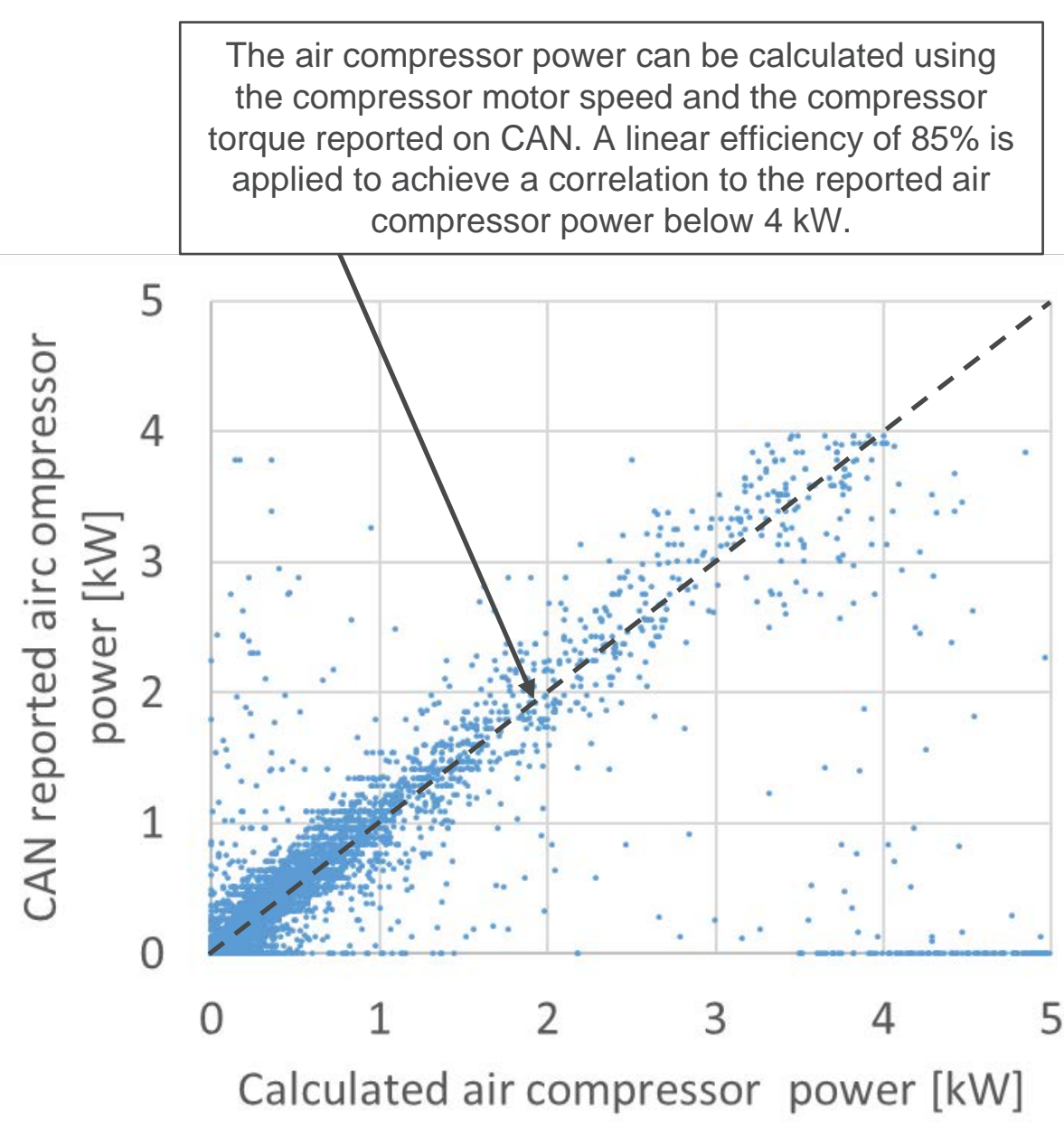

Note:

The $10 \mathrm{~Hz}$ data to generate these graphs is from UDDSx3, Highwayx2, US06x2, maximum acceleration $\times 3$, and steady state speed tests. 


\section{POWERTRAIN ARCHITECTURE AND MEASUREMENTS}

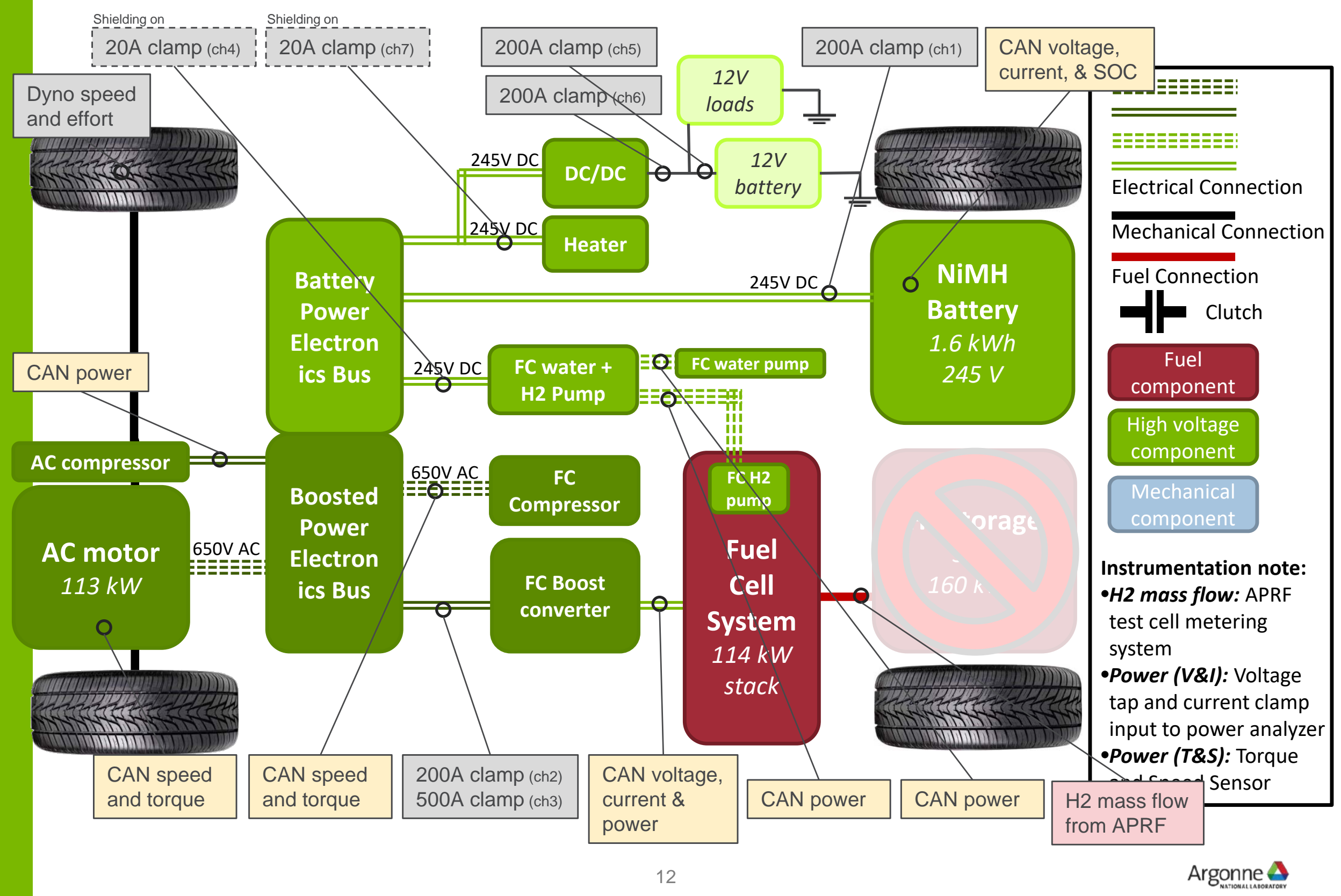




\section{FUEL CELL HYBRID POWERTRAIN OPERATION OVERVIEW}

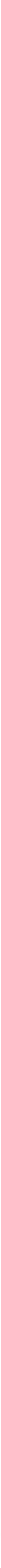




\section{BASIC FUEL CELL HYBRID SYSTEM OPERATION}

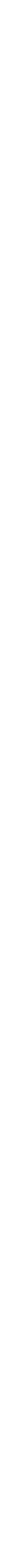




\section{FUEL CELL OPERATION ON AGGRESSIVE DRIVING}

2017 Toyota Mirai

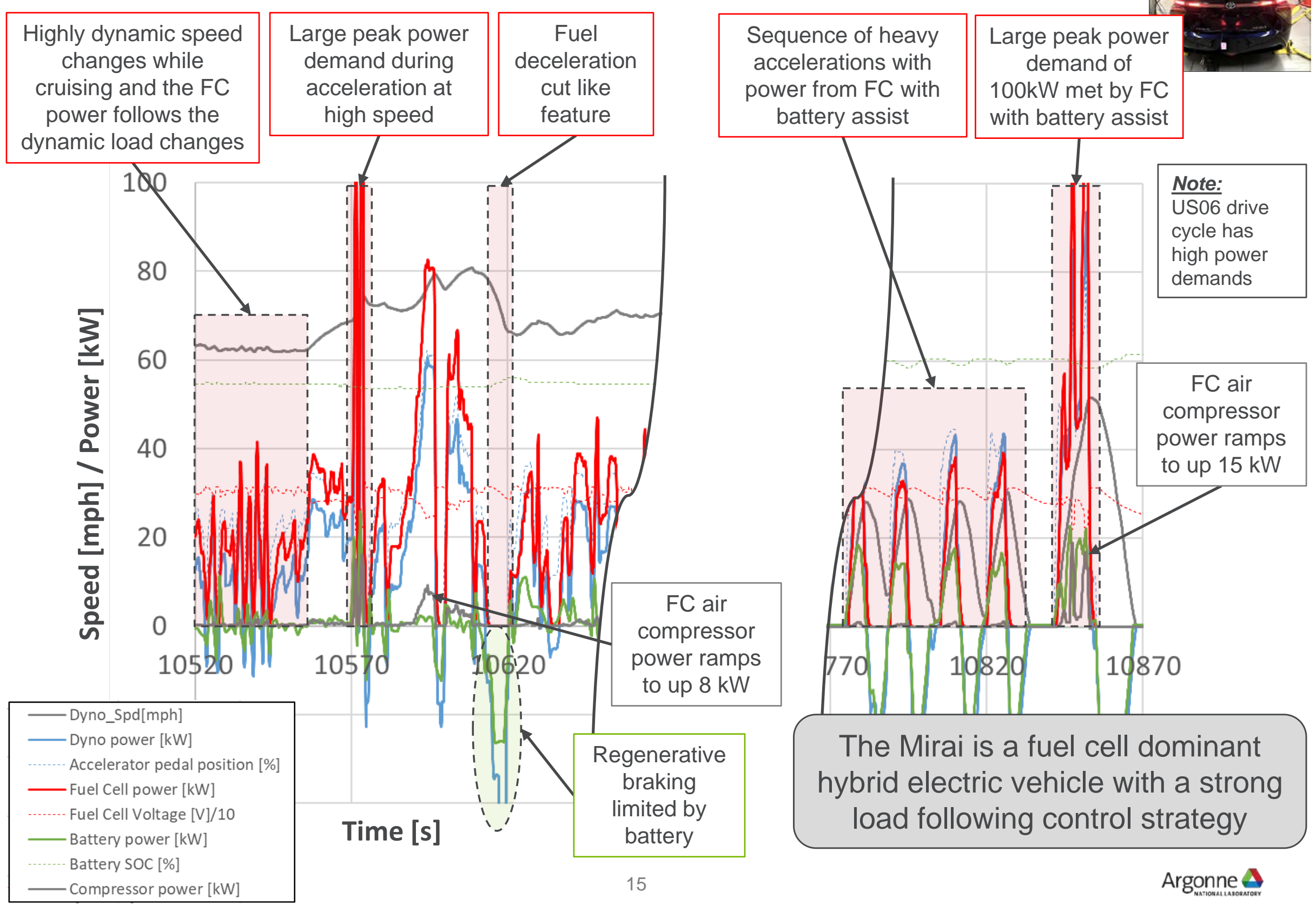




\section{FUEL CELL AND BATTERY USAGE ENVELOPS}
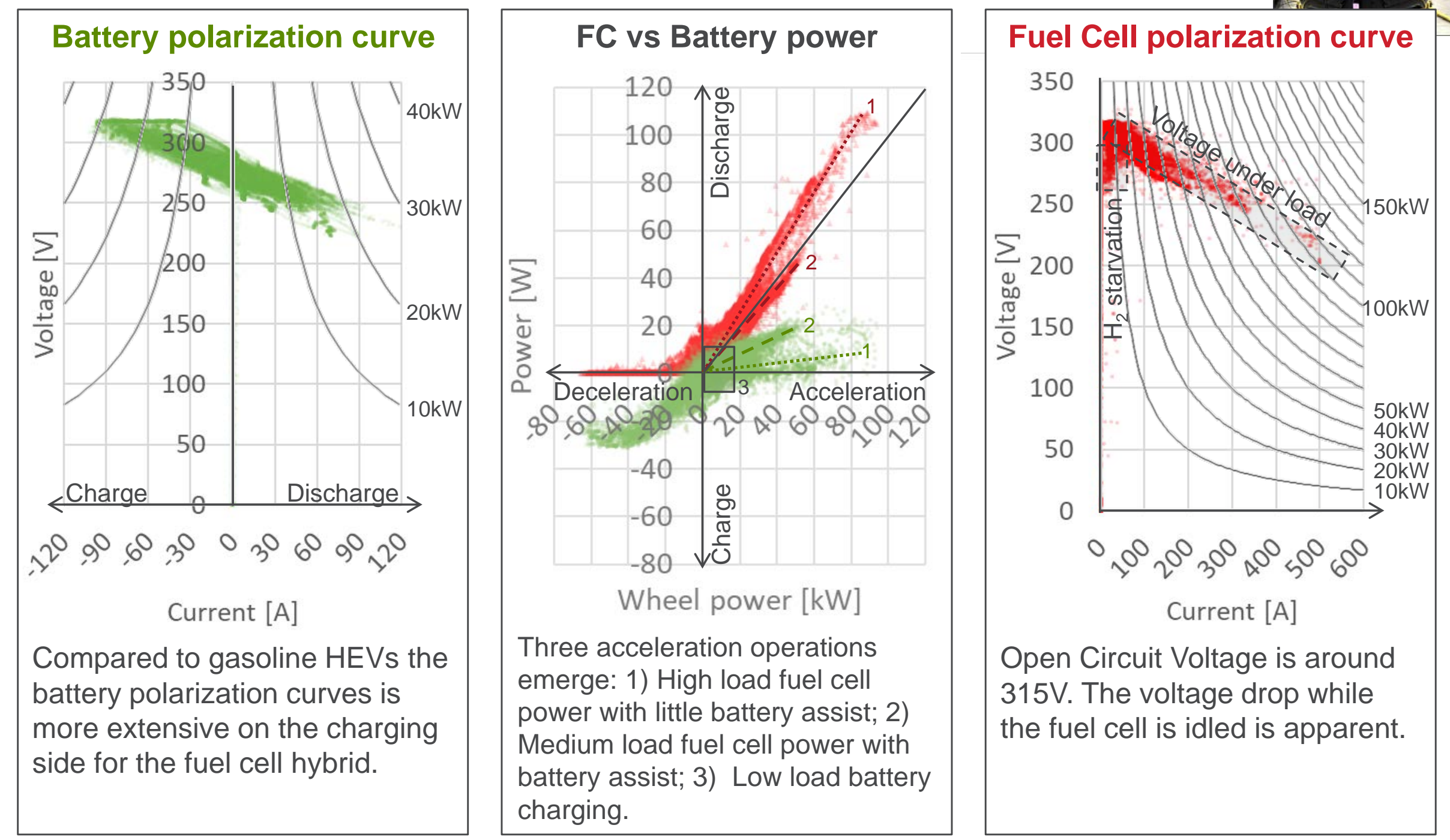

\section{Note:}

The $10 \mathrm{~Hz}$ data to generate these graphs is from NEDCx2, UDDSx3, Highwayx2, US06x2, maximum acceleration $\times 3$, and steady state speed tests. 


\section{FUEL CELL AND BATTERY USAGE ENVELOPS}

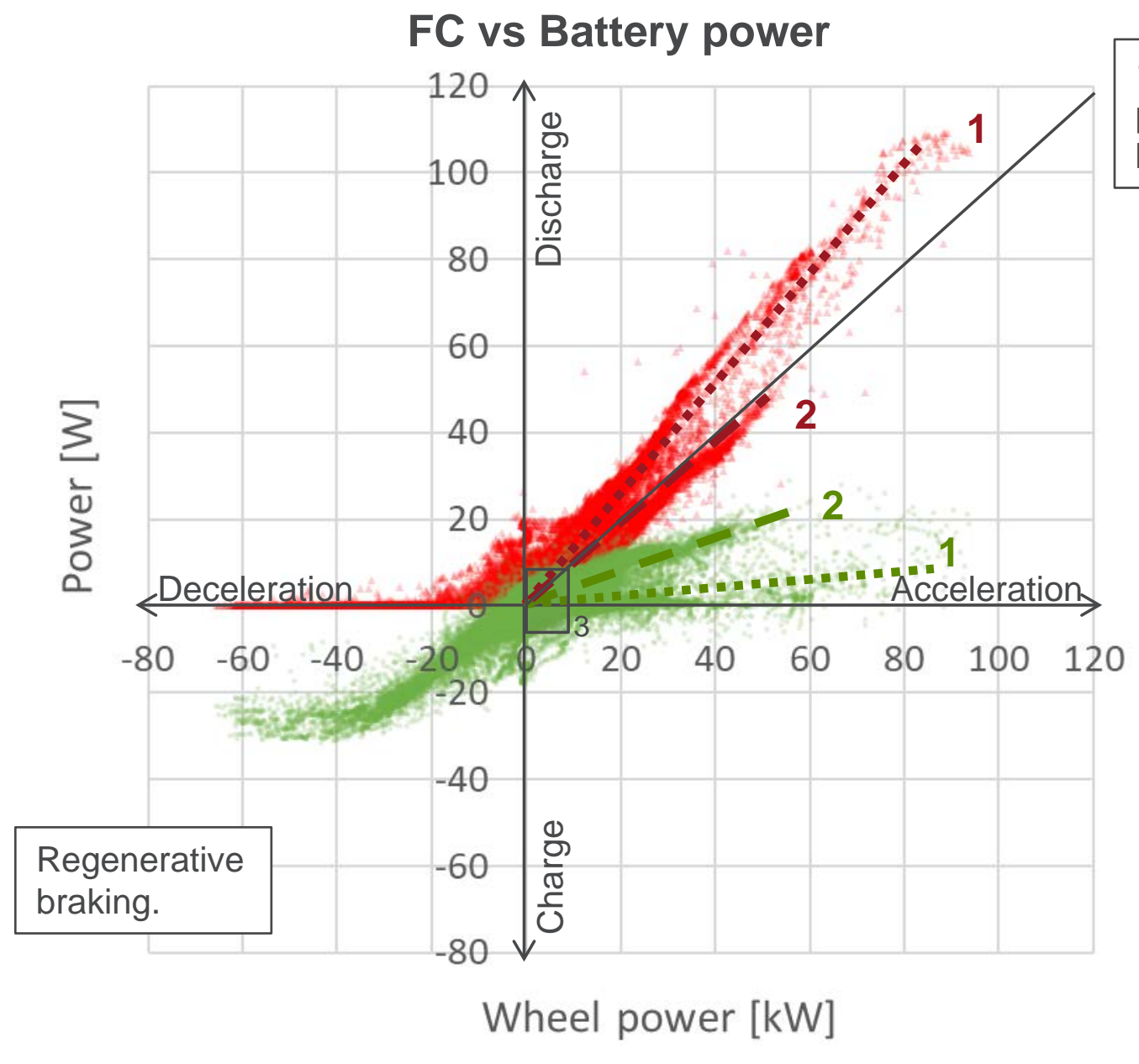

\section{Note:}

The $10 \mathrm{~Hz}$ data to generate these graphs is from NEDCx2, UDDSx3, Highwayx2, US06x2, maximum acceleration $\times 3$, and steady state speed tests.
1) High load fuel cell power with little battery assist;
3) Low load battery charging.
The modeling and simulation team will use the data to validate their current models and control strategies
2) Medium load fuel cell power with battery assist;

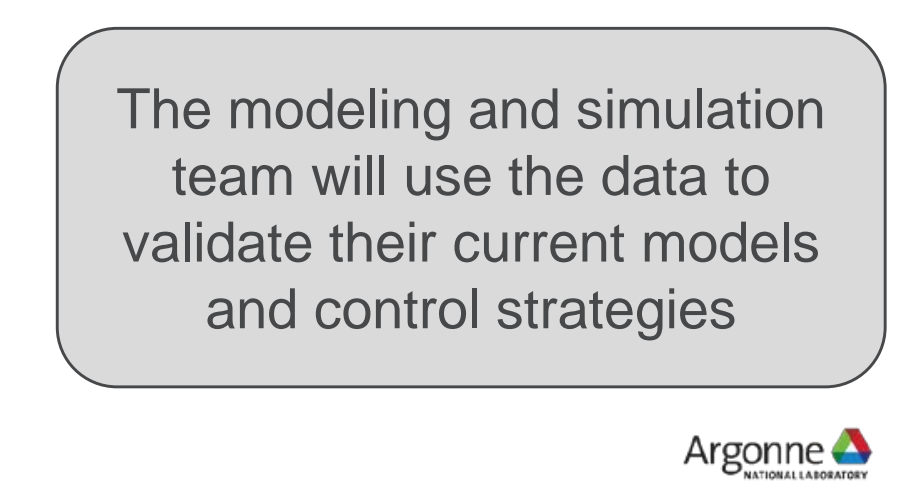




\section{FUEL CELL STACK AND SYSTEM EFFICIENCY (STEADY LOAD MAPPING)}

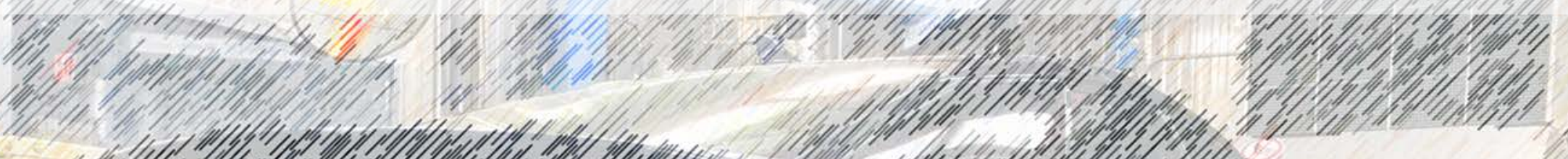

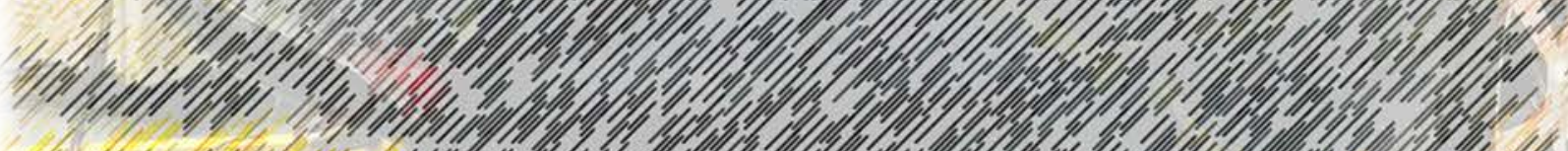
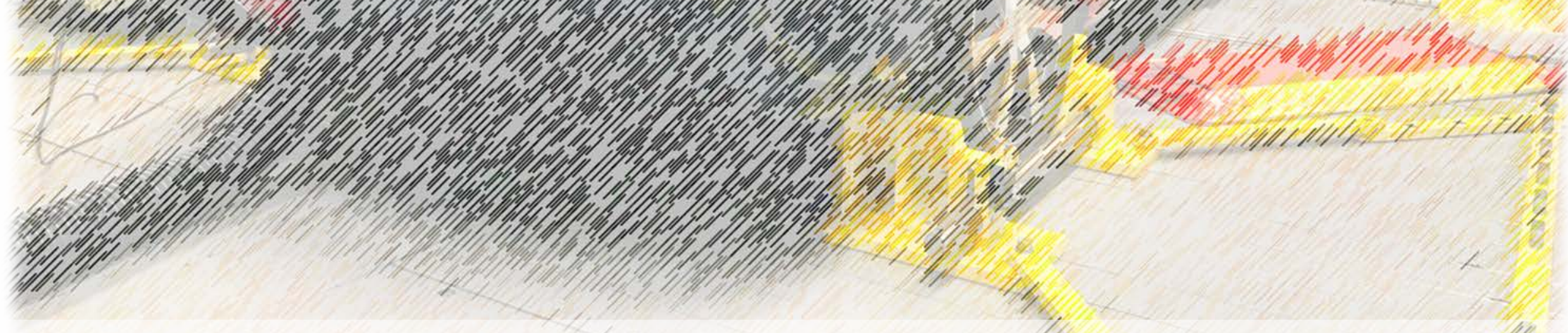


\section{DEFINING THE SYSTEM BOUNDARIES FOR EFFICIENCY CALCULATIONS}

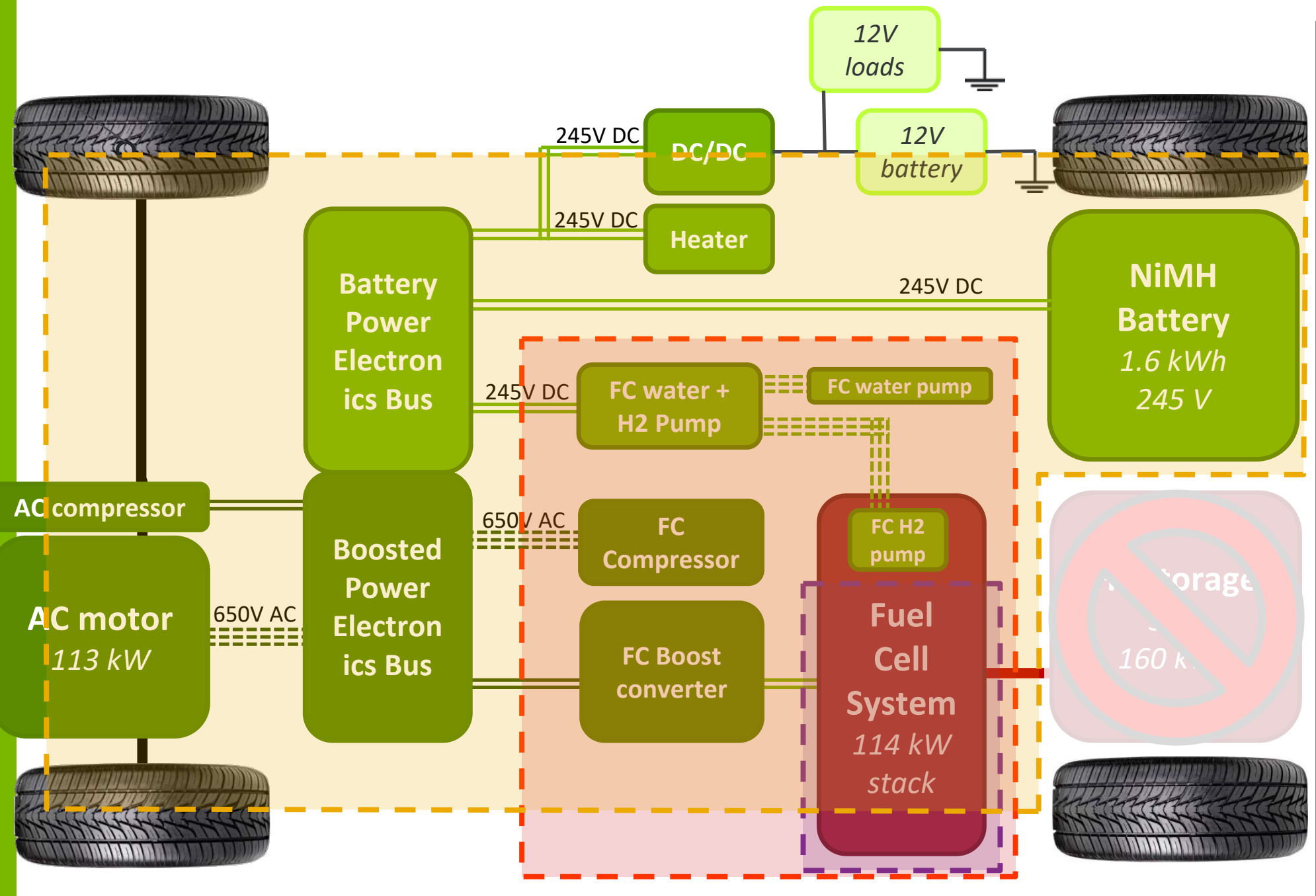

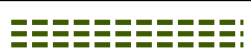

$\underline{\underline{ }}$

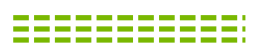

Electrical Connection

Mechanical Connection

Fuel Connection

W Clutch

Fuel

component

High voltage

component

Mechanical

component

Instrumentation note:

- $\mathrm{H} 2$ mass flow: APRF

test cell metering

system

-Power (V\&I): Voltage tap and current clamp input to power analyzer

- Power (T\&S): Torque and Speed Sensor
Vehicle Efficiency (SAE J2951 ${ }^{\mathrm{TM}}$ positive cycle energy based)
Fuel Cell System Efficiency
Fuel Cell Stack Efficiency 


\section{FUEL CELL SYSTEM MAPPING IN VEHICLE ON CHASSIS DYNAMOMETER}

\section{The}

dynamometer is locked at $30 \mathrm{mph}$ for the test and

serves as an power absorption device.
The driver in the vehicle tips into the accelerator pedal to reach specific power level based on the instrumentation.
The driver maintain that power level until power level, fuel flow levels, temperatures stabilize and 'enough' data is recorded to calculate the efficiency with certainty.

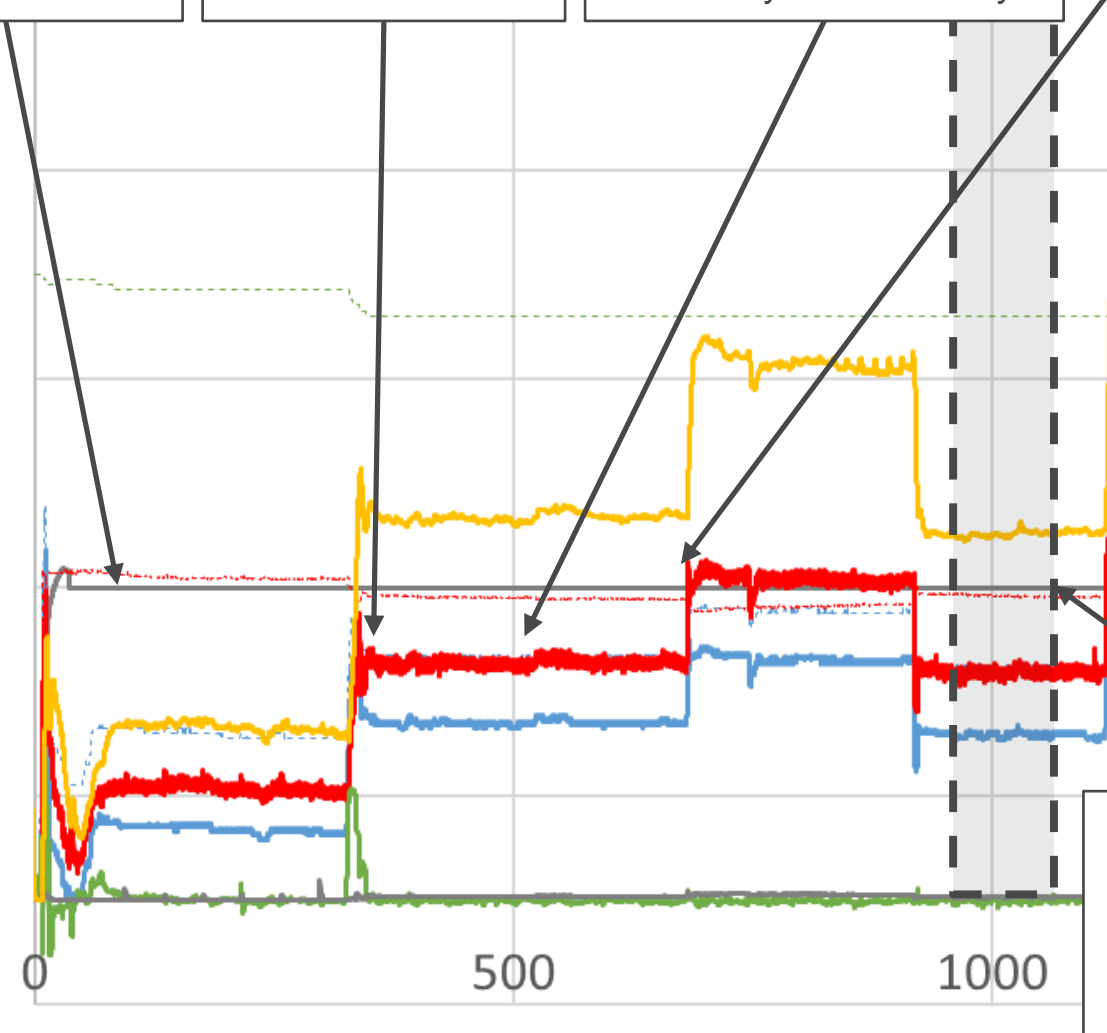

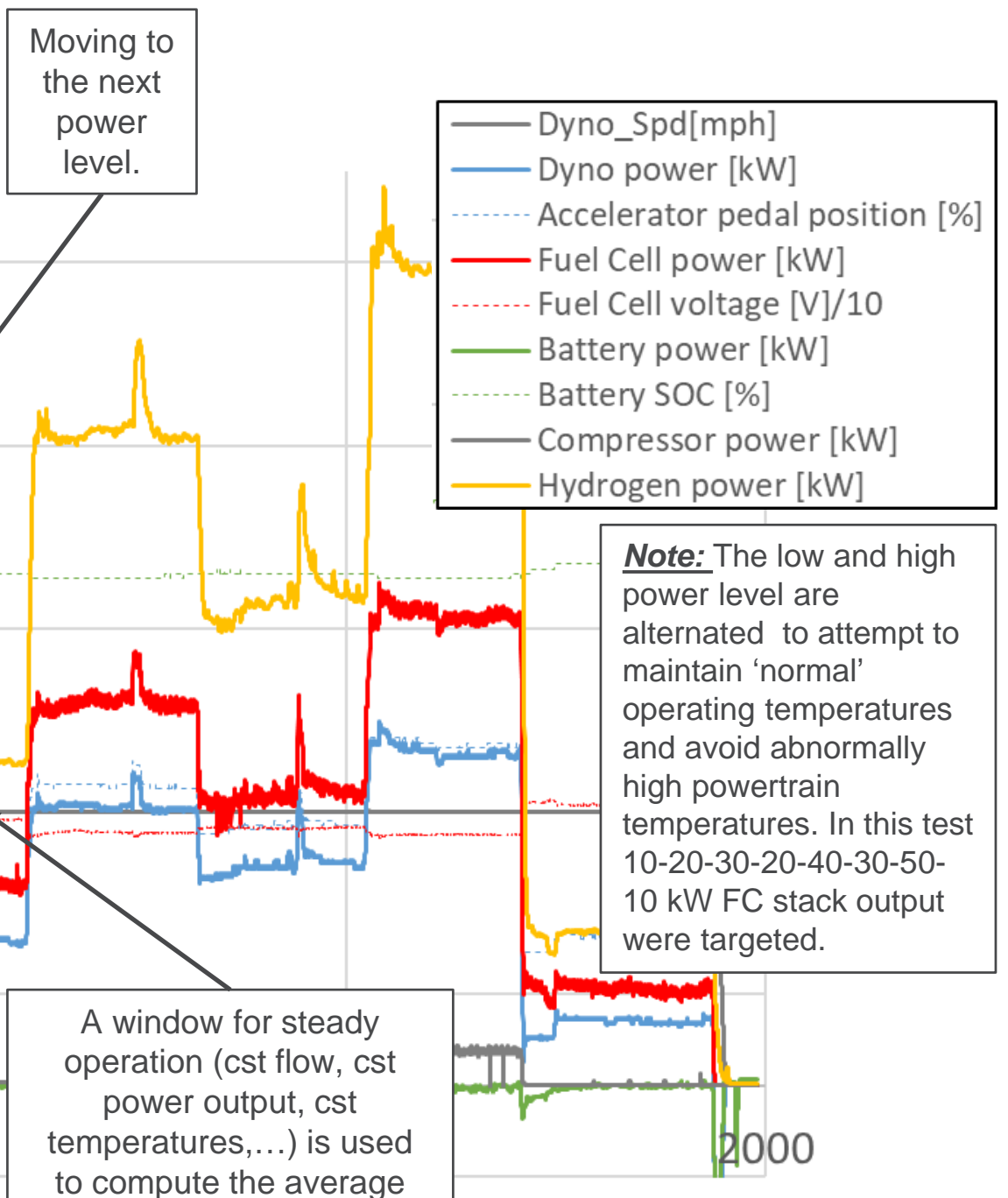
values which are used the efficiency analysis 


\section{FUEL CELL STACK AND SYSTEM EFFICIENCY}

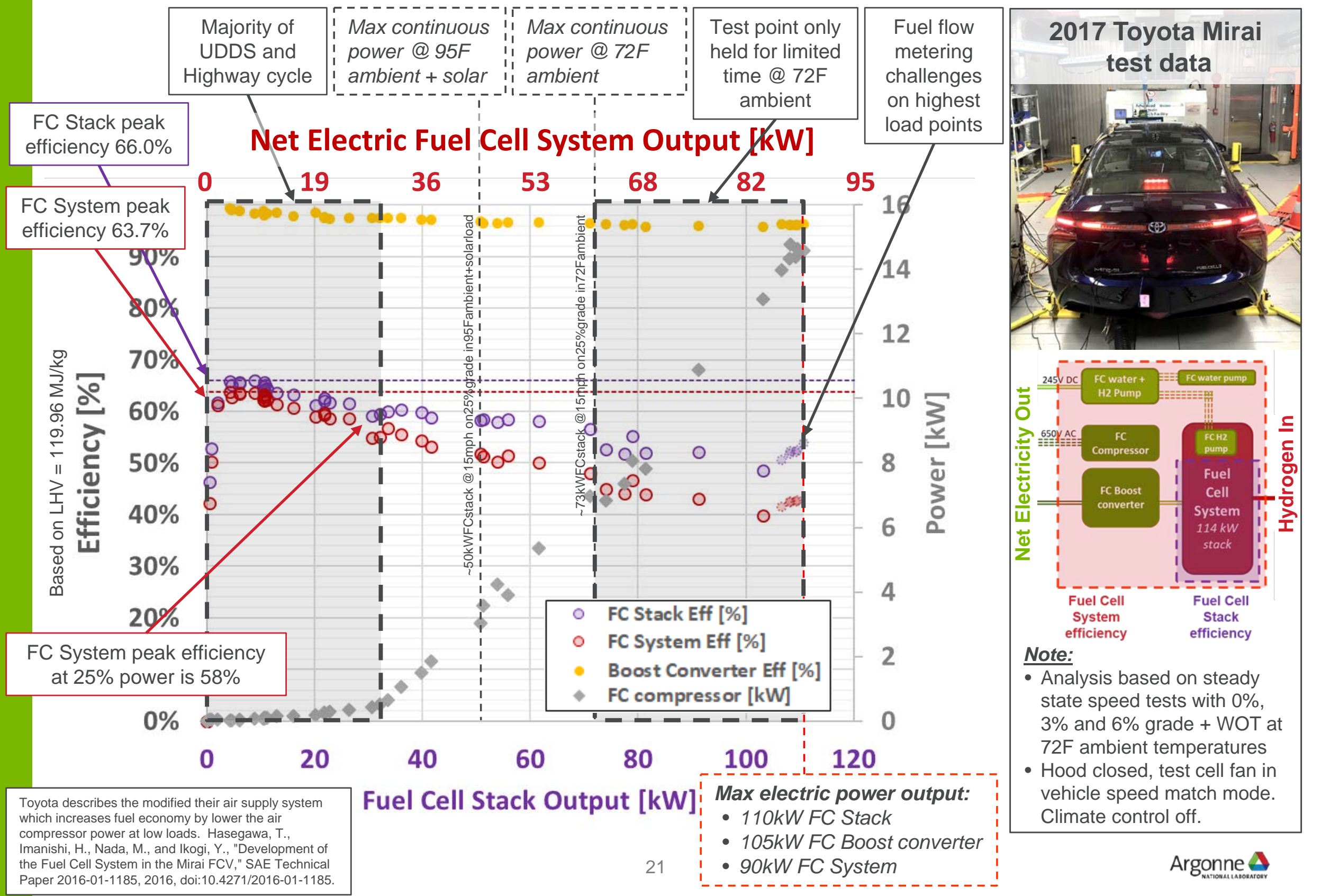




\section{DOE TECHNICAL TARGETS FOR FUEL CELL SYSTEMS AND STACKS FOR TRANSPORTATION APPLICATIONS}

\begin{tabular}{|c|c|c|c|c|}
\hline Characteristic & Units & $\begin{array}{l}2015 \\
\text { Status }\end{array}$ & $\begin{array}{l}2020 \\
\text { Targets }\end{array}$ & $\begin{array}{l}\text { Ultimate } \\
\text { Targets }\end{array}$ \\
\hline Peak energy efficiencyb & $\%$ & $60^{c}$ & 65 & 70 \\
\hline Power density & W/L & $640^{d}$ & 650 & 850 \\
\hline Specific power & W/kg & $659^{e}$ & 650 & 650 \\
\hline Cost $^{f}$ & $\$ / \mathrm{kW}_{\text {net }}$ & $53^{9}$ & 40 & 30 \\
\hline \multicolumn{5}{|l|}{ Cold start-up time to $50 \%$ of rated power } \\
\hline @-20ㄷ ambient temperature & seconds & $20^{\mathrm{h}}$ & 30 & 30 \\
\hline$@+20^{\circ} \mathrm{C}$ ambient temperature & seconds & $<10^{\mathrm{h}}$ & 5 & 5 \\
\hline \multicolumn{5}{|l|}{ Start-up and shutdown energy } \\
\hline from $-20^{\circ} \mathrm{C}$ ambient temperature & $\mathrm{MJ}$ & 7.5 & 5 & 5 \\
\hline from $+20^{\circ} \mathrm{C}$ ambient temperature & MJ & - & 1 & 1 \\
\hline
\end{tabular}

b Ratio of DC output energy to the lower heating value of the input fuel (hydrogen). Peak efficiency occurs at less than $25 \%$ rated power.

c W. Sung, Y. Song, K. Yu, and T. Lim, "Recent Advances in the Development of Hyundai-Kia's Fuel Cell Electric Vehicles," SAE Int. J. Engines 3.1 (2010): 768-772, doi: 10.4271/2010-01-1089.

Table from https://www.energy.gov/eere/fuelcells/doe-technical-targets-fuel-cell-systems-and-stacks-transportationapplications on April 2018

"As a result of the implemented fuel efficiency strategies, the tested Borrego FCEV has attained a fuel cell efficiency of $65 \%$ and thereby fuel cell system efficiency of $62 \%$, in the mean time, the tested Tucson FCEV has achieved a fuel economy of over $72 \mathrm{mpg}$ city. The fuel efficiency was estimated while running at about $60 \mathrm{mph}$ on average whereas the hydrogen consumption was in-house measured based on the FTP-72 test cycle and is represented in miles per gasoline equivalent gallons for comparison purposes .", W. Sung,

\begin{tabular}{|c|c|c|}
\hline & $\begin{array}{l}2008 \\
\text { Hyundai } \\
\text { Borrego }\end{array}$ & $\begin{array}{l}2017 \\
\text { Toyota } \\
\text { Mirai }\end{array}$ \\
\hline Weight & $\begin{array}{l}2300 \mathrm{~kg} \\
\text { reported in } \\
\text { paper }\end{array}$ & $\begin{array}{l}1930 \mathrm{~kg} \\
\text { test weight }\end{array}$ \\
\hline $\begin{array}{l}\text { Fuel Cell } \\
\text { Peak power }\end{array}$ & $\begin{array}{l}\text { PEM } \\
100 \mathrm{~kW}\end{array}$ & $\begin{array}{l}\text { PEM } \\
114 \mathrm{~kW}\end{array}$ \\
\hline $\begin{array}{l}\text { Fuel } \\
\text { Economy } \\
\text { on FTP } 72 \\
\text { (aka UDDS) }\end{array}$ & 72 mpge & $\begin{array}{l}\text { Cold start } \\
91.5 \text { mpge } \\
\text { Hot start } \\
95.3 \text { mpge }\end{array}$ \\
\hline $\begin{array}{l}\text { FC stack } \\
\text { efficiency } \\
\text { at } 60 \mathrm{mph}\end{array}$ & $65 \%$ & $63.2 \%$ \\
\hline $\begin{array}{l}\text { FC system } \\
\text { efficiency } \\
\text { at } 60 \mathrm{mph}\end{array}$ & $62 \%$ & $60.6 \%$ \\
\hline $\begin{array}{l}\text { Peak FC } \\
\text { stack } \\
\text { efficiency }\end{array}$ & $65 \%$ & $\begin{array}{c}66.0 \% @ 5 \\
\text { to } 10 \mathrm{~kW} \\
\text { stack output }\end{array}$ \\
\hline $\begin{array}{l}\text { Peak FC } \\
\text { system } \\
\text { efficiency }\end{array}$ & $62 \%$ & $\begin{array}{c}63.7 \% @ 5 \\
\text { to } 10 \mathrm{~kW} \\
\text { stack output }\end{array}$ \\
\hline
\end{tabular}

Argonne 


\section{COMPARISON OF SERIES HYBRID "GENERATORS"}

Fuel Cell

Hybrid Electric Vehicle:

- Charge sustain

- Fuel Cell dominant

- Generator max output 114 kW

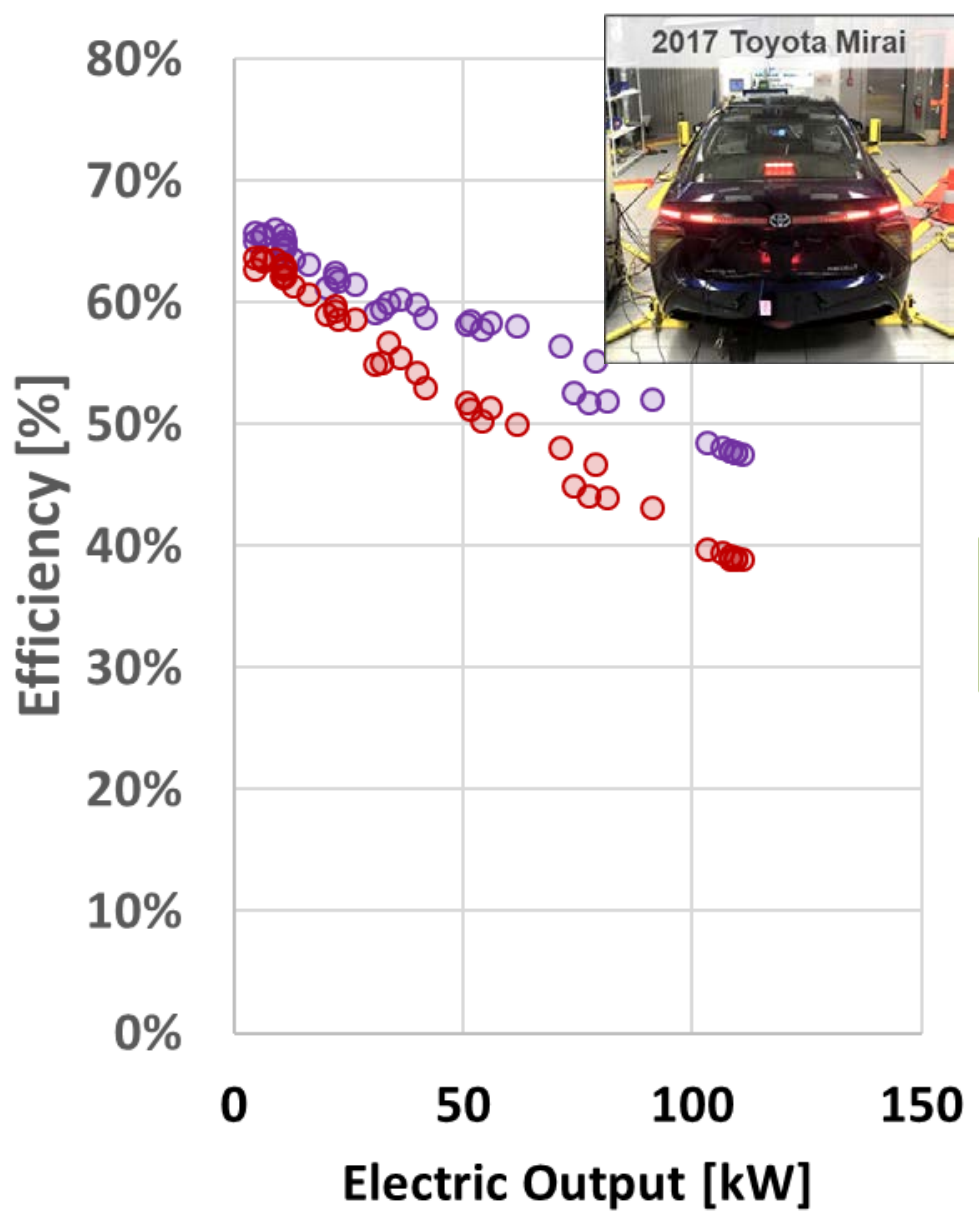

Battery Electric Vehicle with range extender:

- Primarily BEV

- Small 649cc 2cyl engine

- Generator max output 25 kW
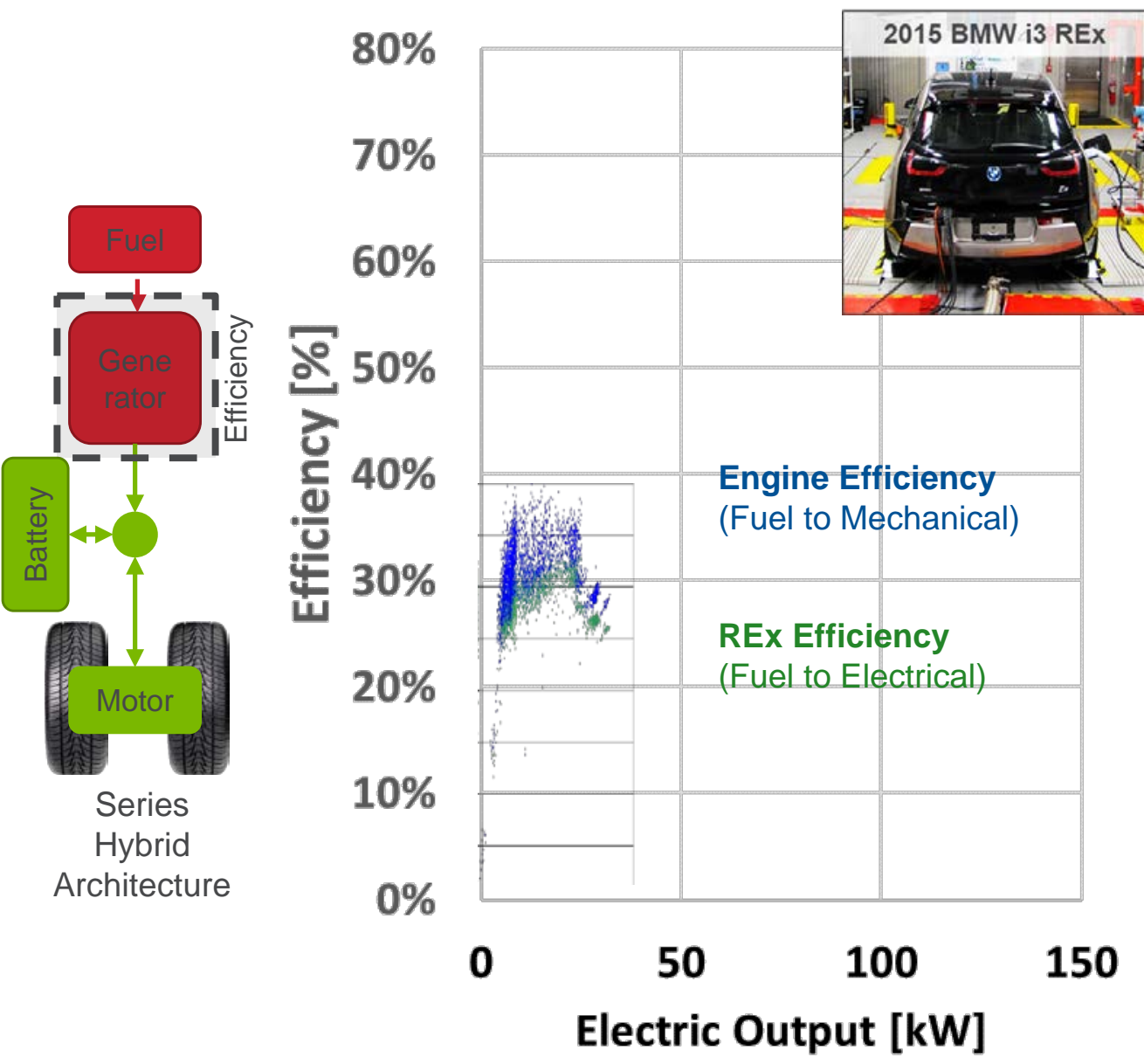

Argonne 


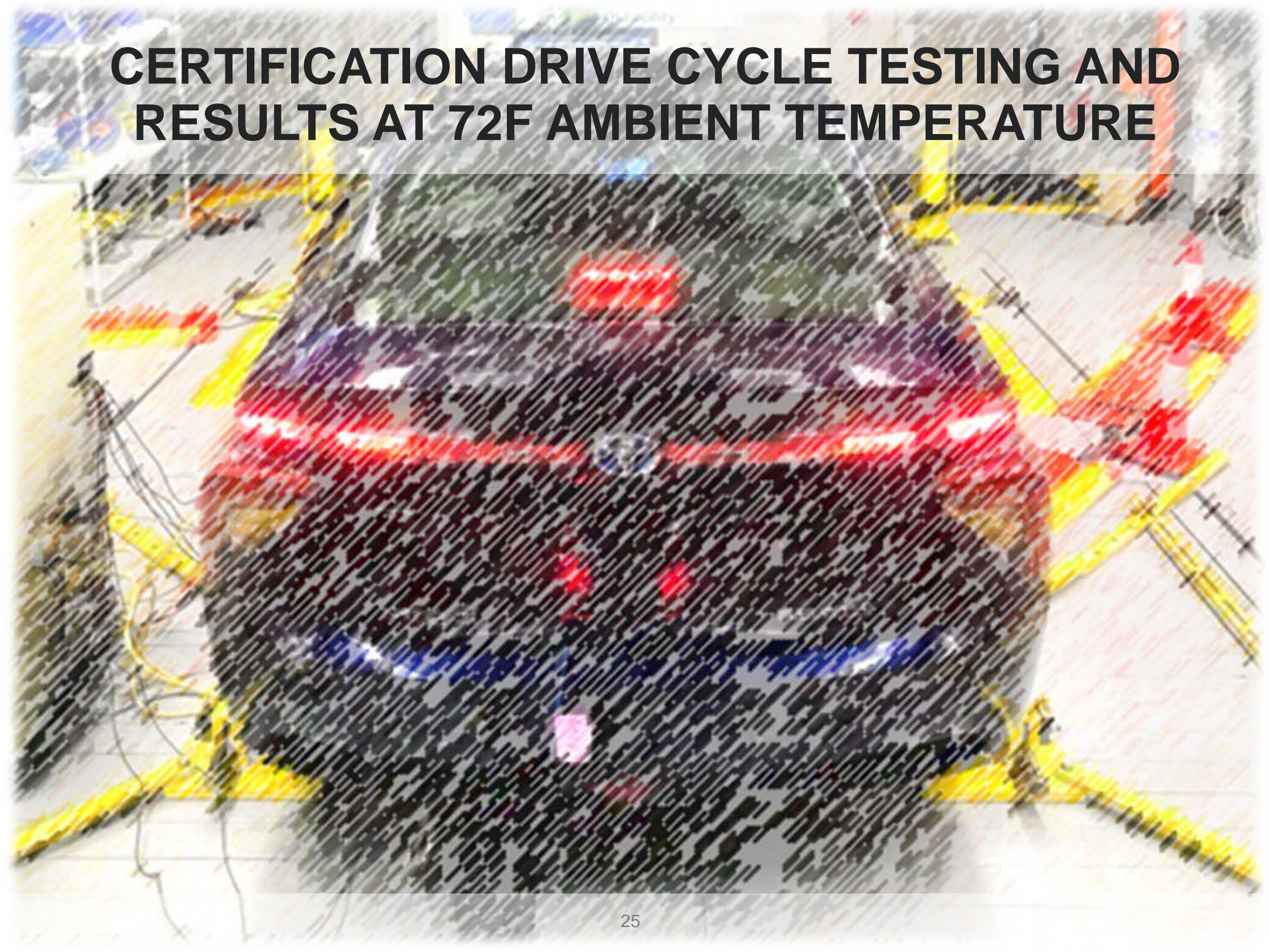




\section{STANDARD TEST SEQUENCE FOR CERTIFICATION TESTS}

Prep UDDS cycle completed followed by Cold Start vehicle temperature
soak over night in the

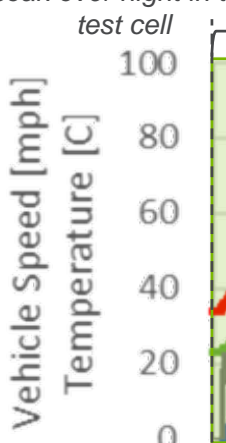

0

\section{UDDS\#1}
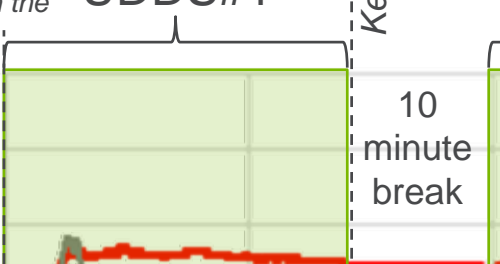

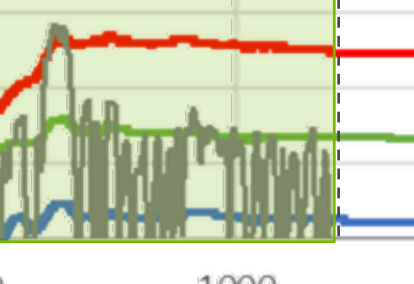

0

1000

$$
2000
$$

Hot Start UDDS\#2

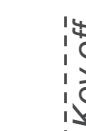

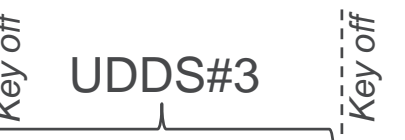

$\mathrm{FC}$

'Reactor' temperature

Report fue economy from these cycles

\section{Powertrain thermal conditions \\ - 'Cold Start' test means that the vehicle, and therefore the powertrain, was soaked at the target ambient temperature for over 12 hours before the start of the test. 16 hours is the typical soak time in the test cell on the dynamometer for this testing. \\ - 'Hot Start' test means that the vehicle just completed a test and that the powertrain is already warm. Argonne tries to keep 10 minutes between the end of a test and the start of the hot start test.}

Cooling setup: The test cell fan was run dynamically to match the air flow speed to the vehicle speed and the hood was closed for al testing regardless of ambient temperature.

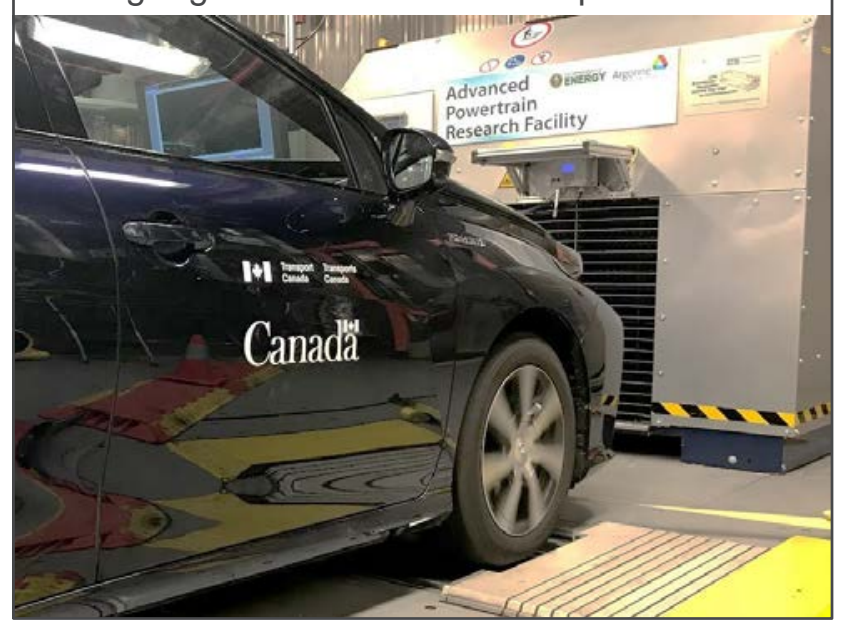

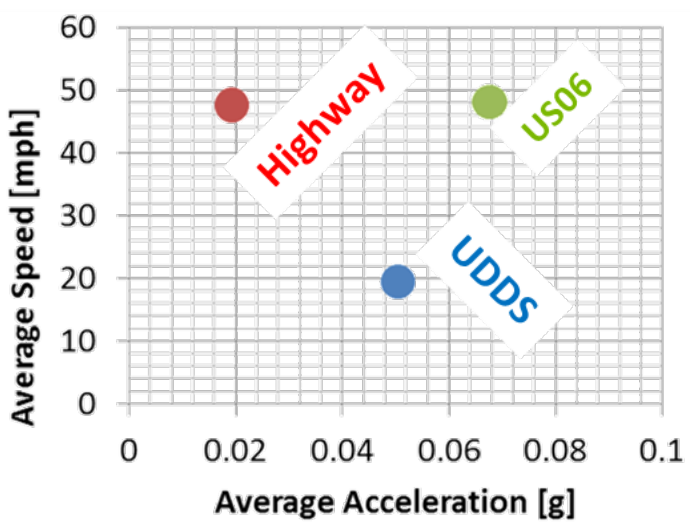

Argonne 


\section{CERTIFICATION CYCLES TEST RESULT AT 72F AMBIENT TEMPERATURE}
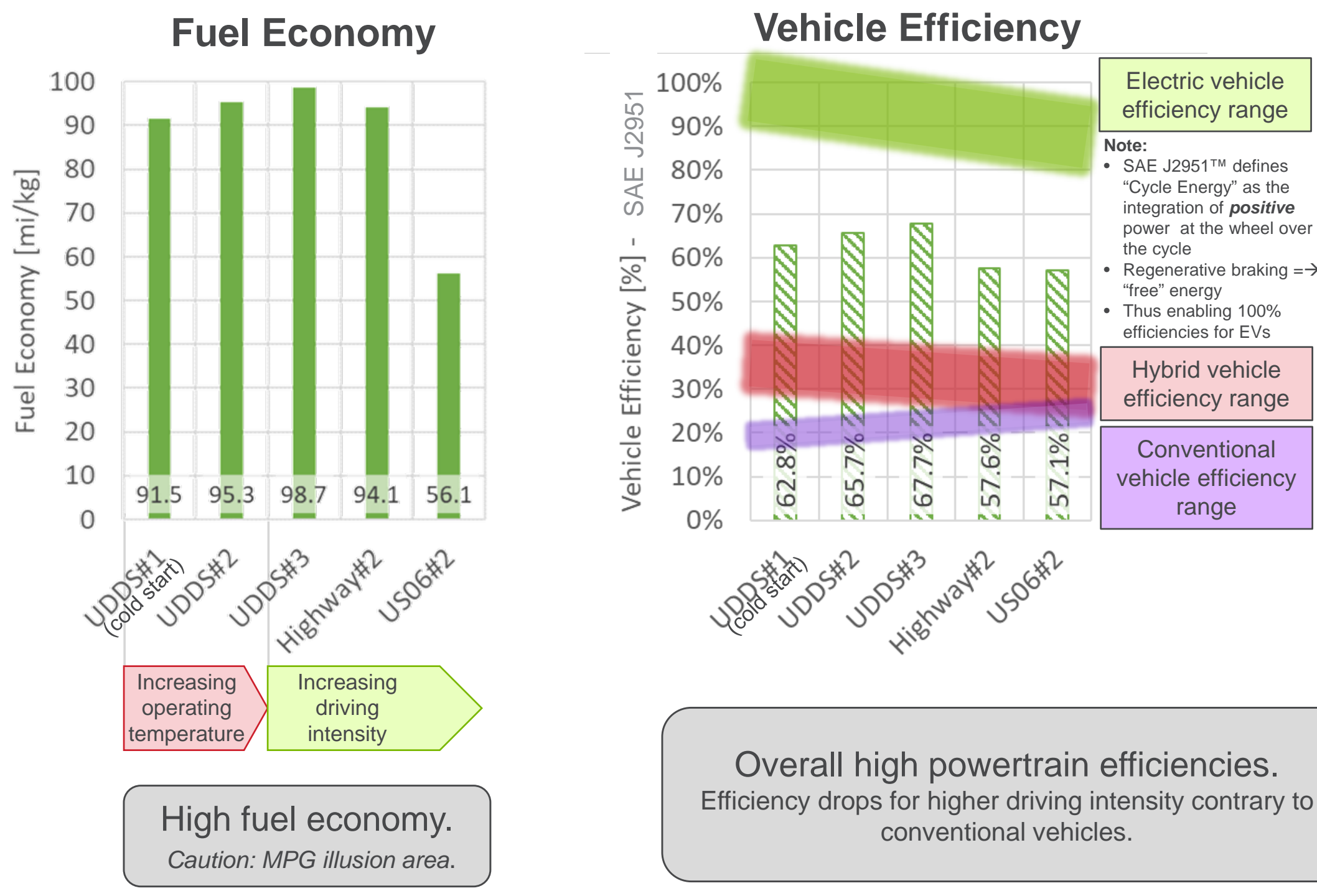

Overall high powertrain efficiencies.

Efficiency drops for higher driving intensity contrary to conventional vehicles. 


\section{FUEL ECONOMY COMPARISON TO EPA RESULTS}

\section{Argonne test results appear to match the EPA published test results}

\begin{tabular}{|l|c|c|}
\hline Test & EPA(1) & ANL \\
\hline $\begin{array}{l}\text { FTP } 75 \text { (43\% cold } \\
\text { start and } 57 \% \text { hot start) }\end{array}$ & 94.1 mpge (2) & 91.9 mpge \\
\hline Highway & 94.1 mpge (2) & 92.4 mpge \\
\hline Testing & $\begin{array}{l}\text { Manufacturer } \\
\text { submitted to EPA }\end{array}$ & ANL internal \\
\hline
\end{tabular}

(1) The data comes from the EPA testing database published on their website: https://www.epa.gov/compliance-and-fuel-economy-data/data-cars-used-testing-fueleconomy

(2) The EPA file indicate the "FE_UNIT" to be "MPG". It has been suggest that the units are "mi/kg" in which case using a Petroleum Equivalent Factor (PEF) of 1.02 $\left(\mathrm{H}_{2} \mathrm{~kg} / \mathrm{gallon}\right)$ the EPA fuel economy is 96.0 mpge for FTP75 and Highway. Argonne was not able to confirm if this is a mistake in the EPA file.
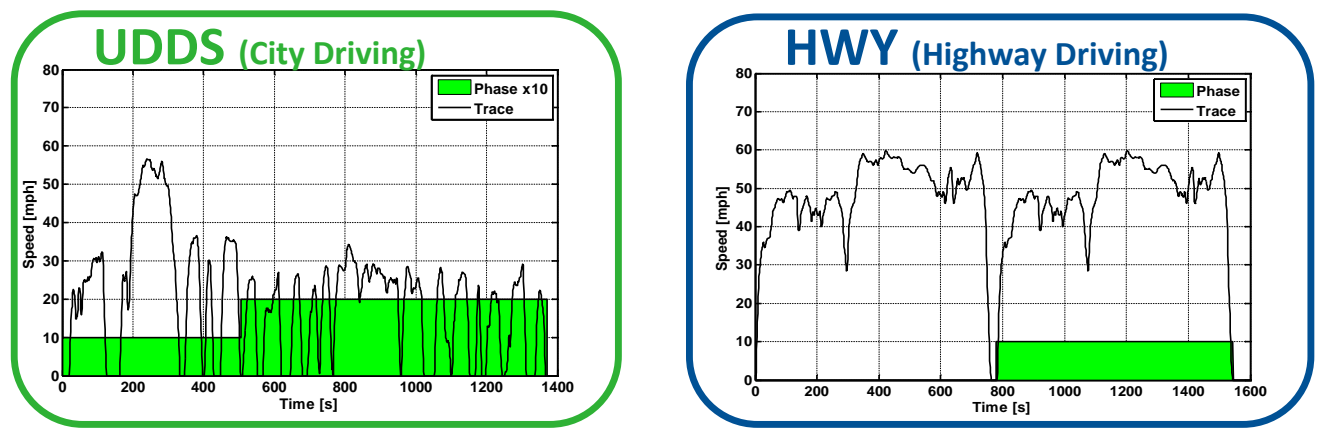

\begin{tabular}{|l|}
\hline \multicolumn{2}{|c|}{2017 Toyota Mirai } \\
\hline
\end{tabular}




\section{WHERE DID THE ENERGY GO?}

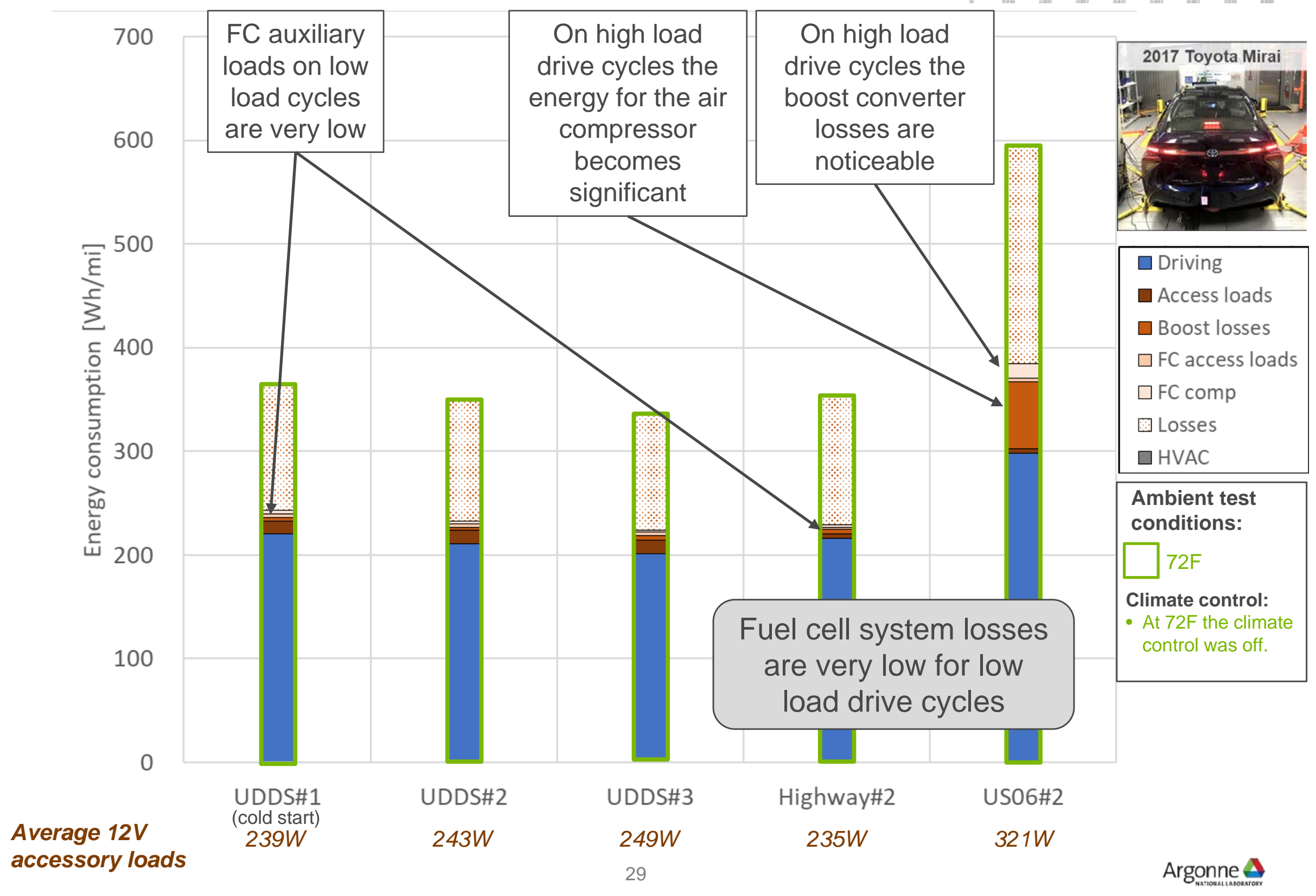




\section{FUEL CELL VEHICLE EFFICIENCY CONTEXT}
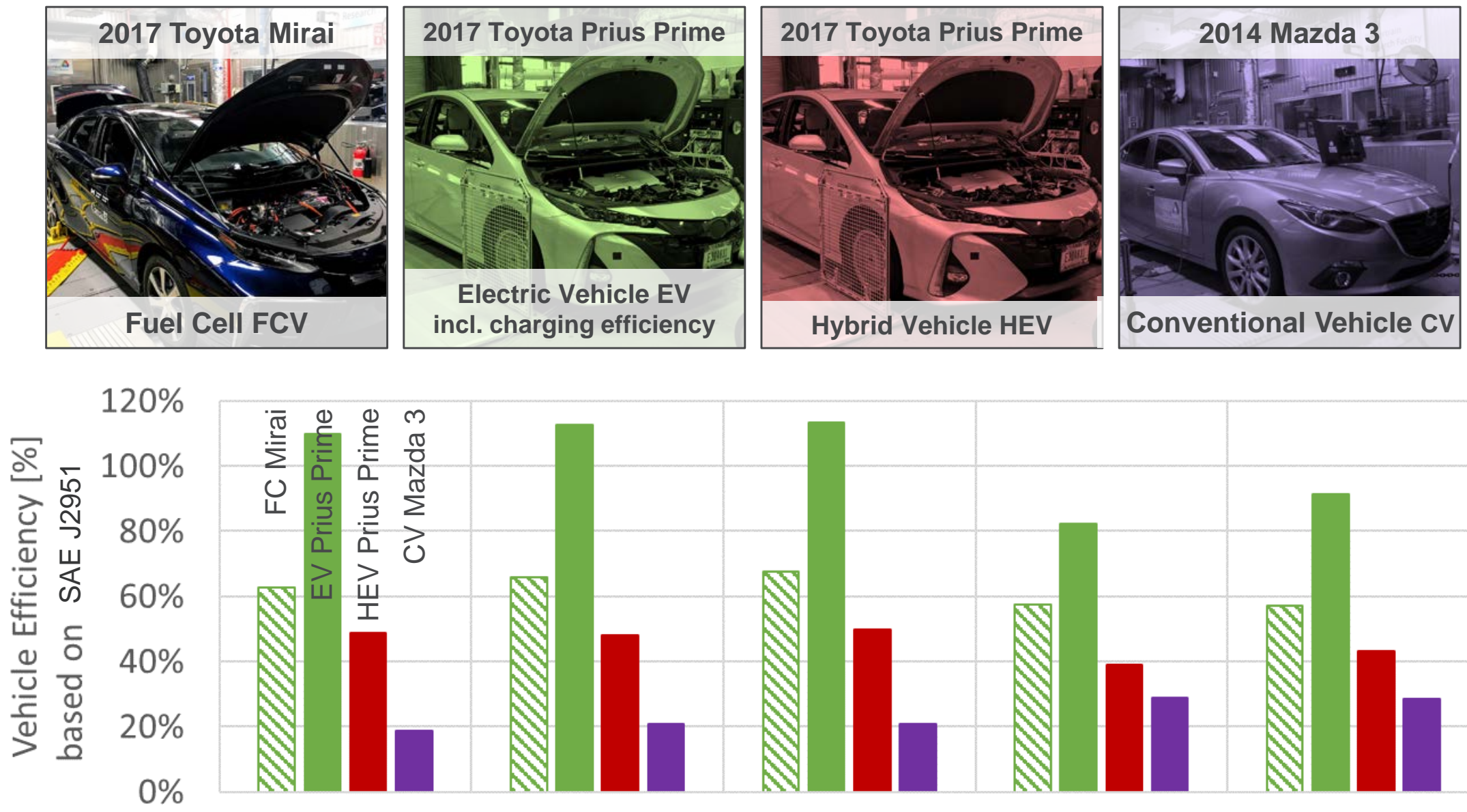

UDDS\#1

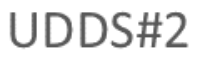

\section{UDDS\#3}

Highway\#2

US06\#2

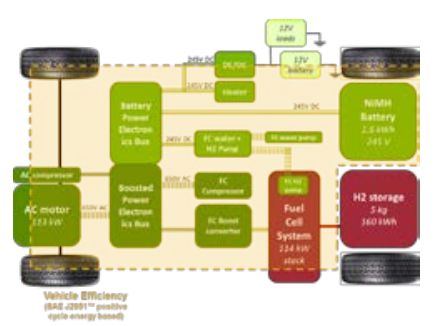

The fuel cell vehicle efficiency is higher compared to vehicles that use an internal combustion engine. 


\section{FUEL CELL SYSTEM PEAK EFFICIENCY CORRELATES WITH VEHICLE DEMANDS}

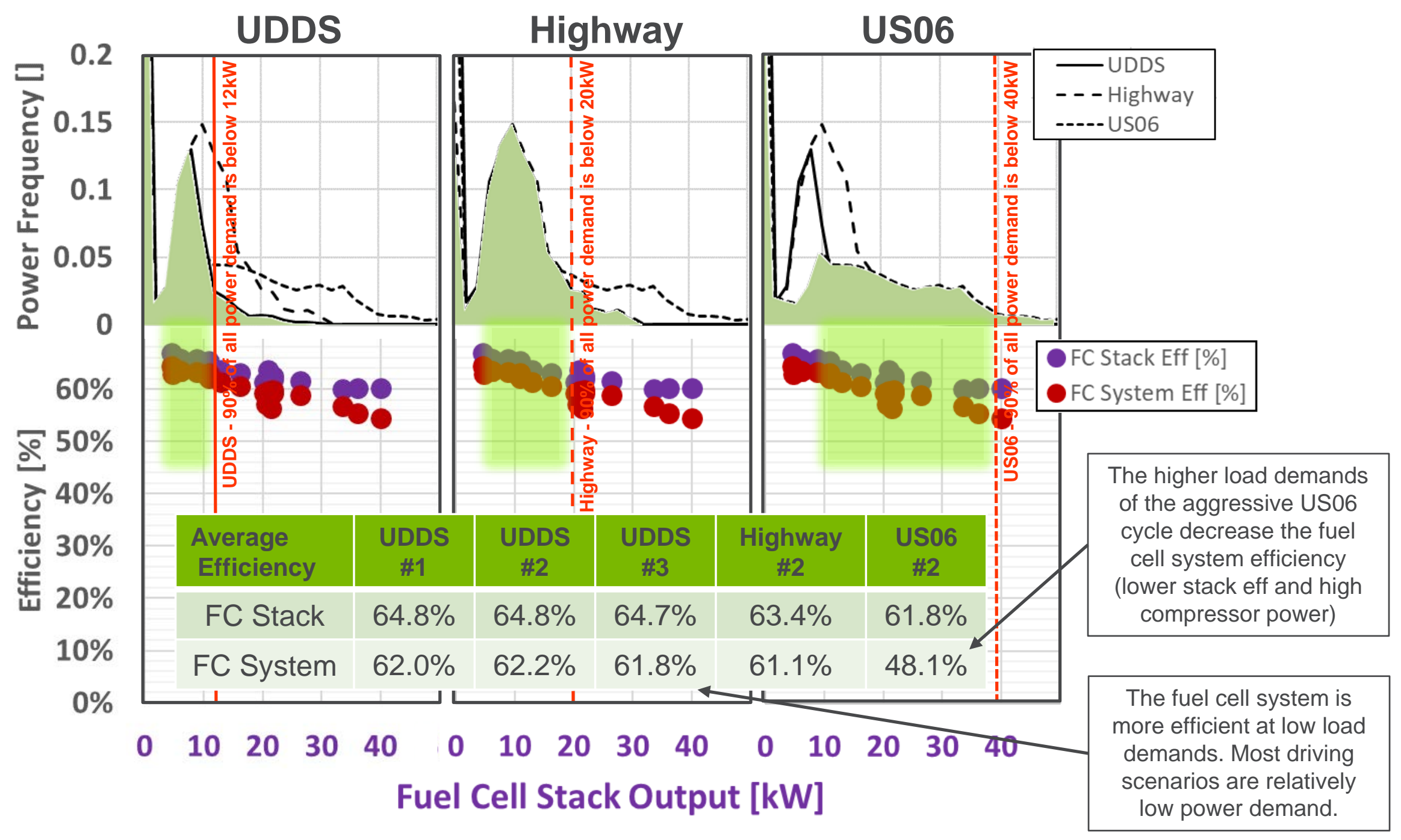




\section{FURTHER DRIVE CYCLE RESULTS AT 72F AMBIENT TEMPERATURE}

UDDS\#2 Highway\#2 US06\#2 JC08\#2 NEDC\#2 WLTP\#2

Fuel economy [mpge]

Hydrogen consumed [kWh]

Fuel consumption [kWh/mi]

Average FC Stack efficiency [\%]

Average FC System efficiency [\%]

Vehicle efficiency [\%]

FC power covering $90 \%$ demand $[\mathrm{kW}]$

\begin{tabular}{|c|c|}
\hline 93.5 & 92.4 \\
\hline 2.60 & 3.63 \\
\hline 349.7 & 354.0 \\
\hline $64.8 \%$ & $63.4 \%$ \\
\hline $62.2 \%$ & $61.1 \%$ \\
\hline $65.7 \%$ & $57.6 \%$ \\
\hline 12 & 20 \\
\hline
\end{tabular}

55.0

4.76

594.2

$61.8 \%$

$48.1 \%$

$57.1 \%$

40
94.8

1.76

344.8

$64.2 \%$

$57.7 \%$

$65.0 \%$

12
85.9

2.61

380.5

$62.4 \%$

$59.3 \%$

$58.2 \%$
90.8

6.34

441.6

$61.8 \%$

$56.9 \%$

$59.0 \%$

,

UDDS

Highway

US06

JC08

NEDC

WLTP
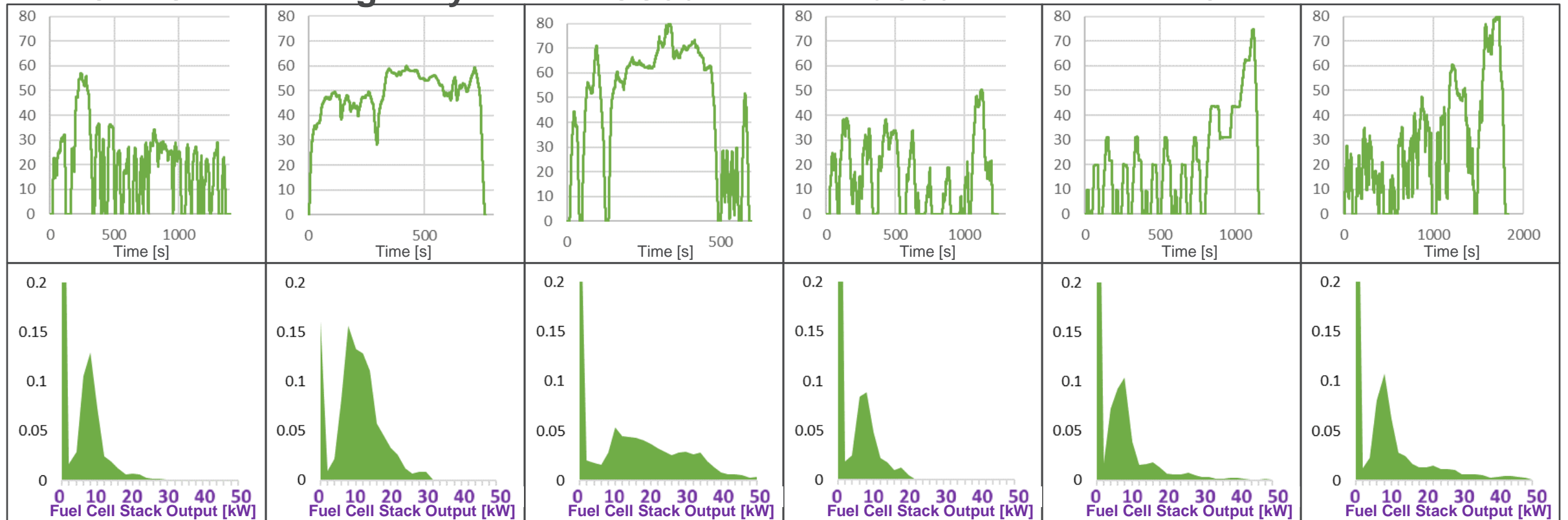

Note: Each drive cycle was tested in pairs back to back. The results presented in the table are from the second cycle. The second cycles were always charge sustain by net energy change (less than $1 \%$ of fuel energy) and SOC (delta $=0 \%$ ) 


\section{FUEL CONSUMPTION WITH BATTERY STATE OF CHARGE CORRECTION}

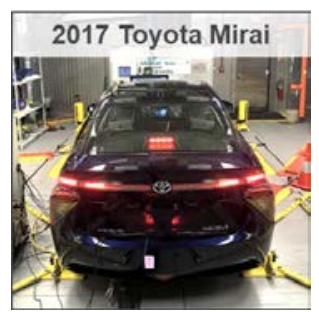

Note: The battery SOC was adjusted to high and low before the beginning of specific UDDS tests to obtain the results below.

\section{Same approach as for other} Hybrid Electric Vehicles.

\section{UDDS drive cycles}

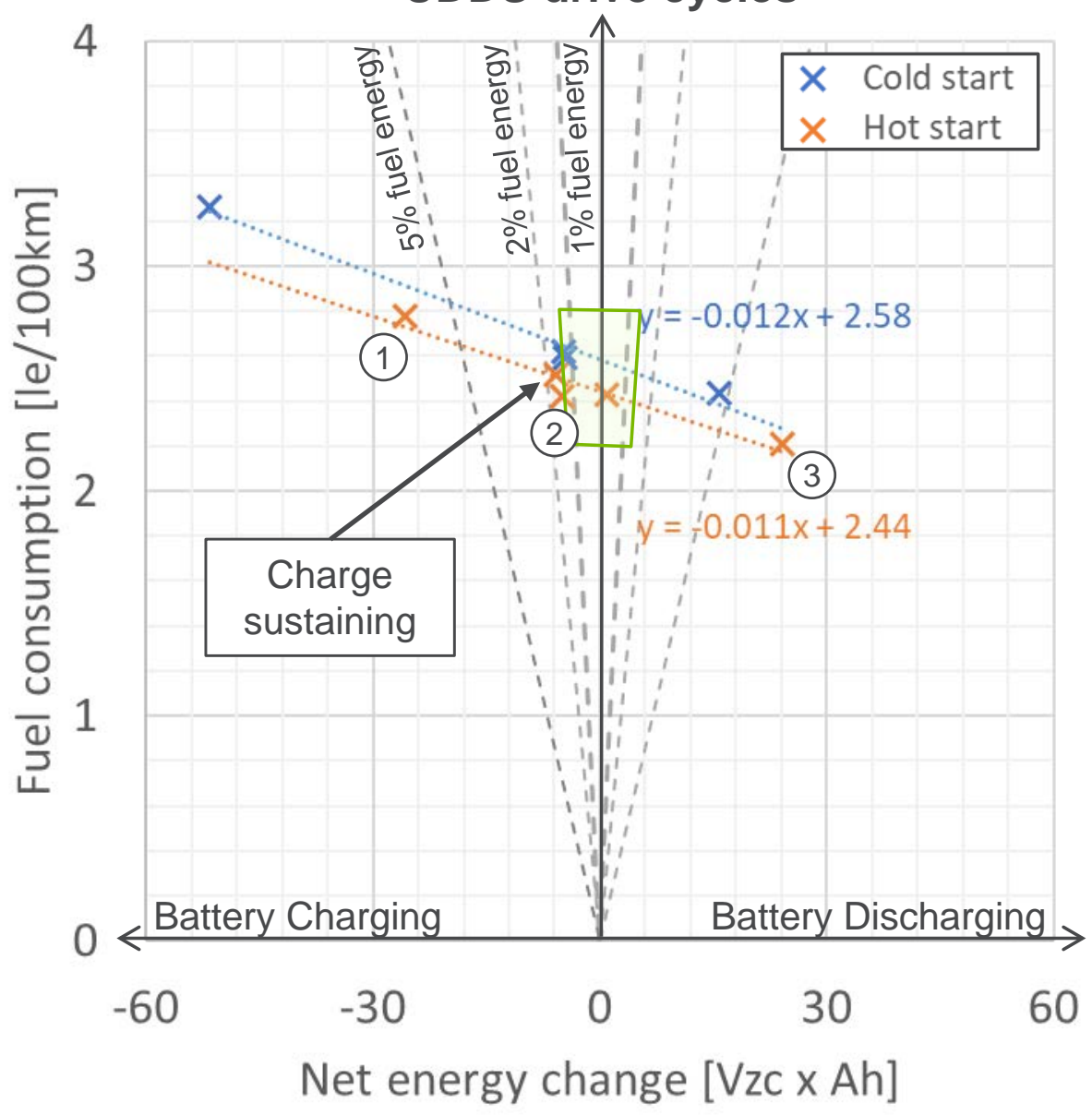

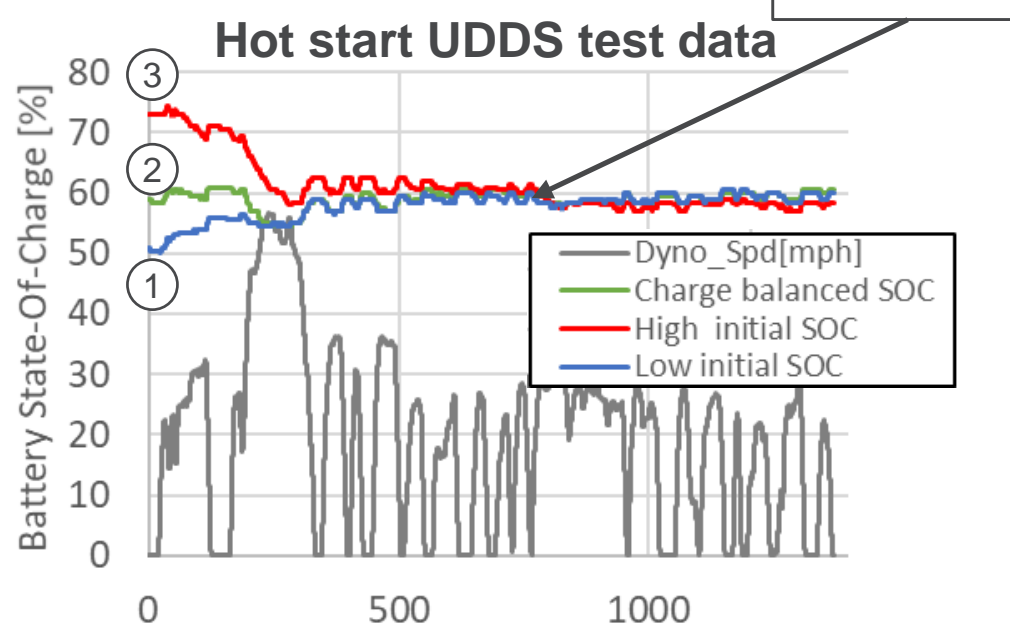

\begin{tabular}{|c|c|c|c|c|}
\hline & $\begin{array}{l}\text { SOC } \\
\text { Start } \\
{[\%]}\end{array}$ & $\begin{array}{l}\text { soc } \\
\text { End } \\
\text { [\%] }\end{array}$ & $\begin{array}{l}\text { Fuel } \\
\text { Consum } \\
\text { ption } \\
{[\text { [le/100km] }}\end{array}$ & $\begin{array}{l}\text { Net } \\
\text { energy } \\
\text { change } \\
{[\text { [VzC XAh] }}\end{array}$ \\
\hline Low initial SOC & 51 & 60 & 2.78 & -25.7 \\
\hline Charge balanced SOC & 59 & 60.5 & 2.52 & -5.7 \\
\hline High initial SOC & 73 & 58.5 & 2.21 & 24.2 \\
\hline
\end{tabular}




\section{HYDROGEN CONSUMPTION BASED ON CYLINDER PRESSURE, VOLUME, AND “TEMPERATURE”}
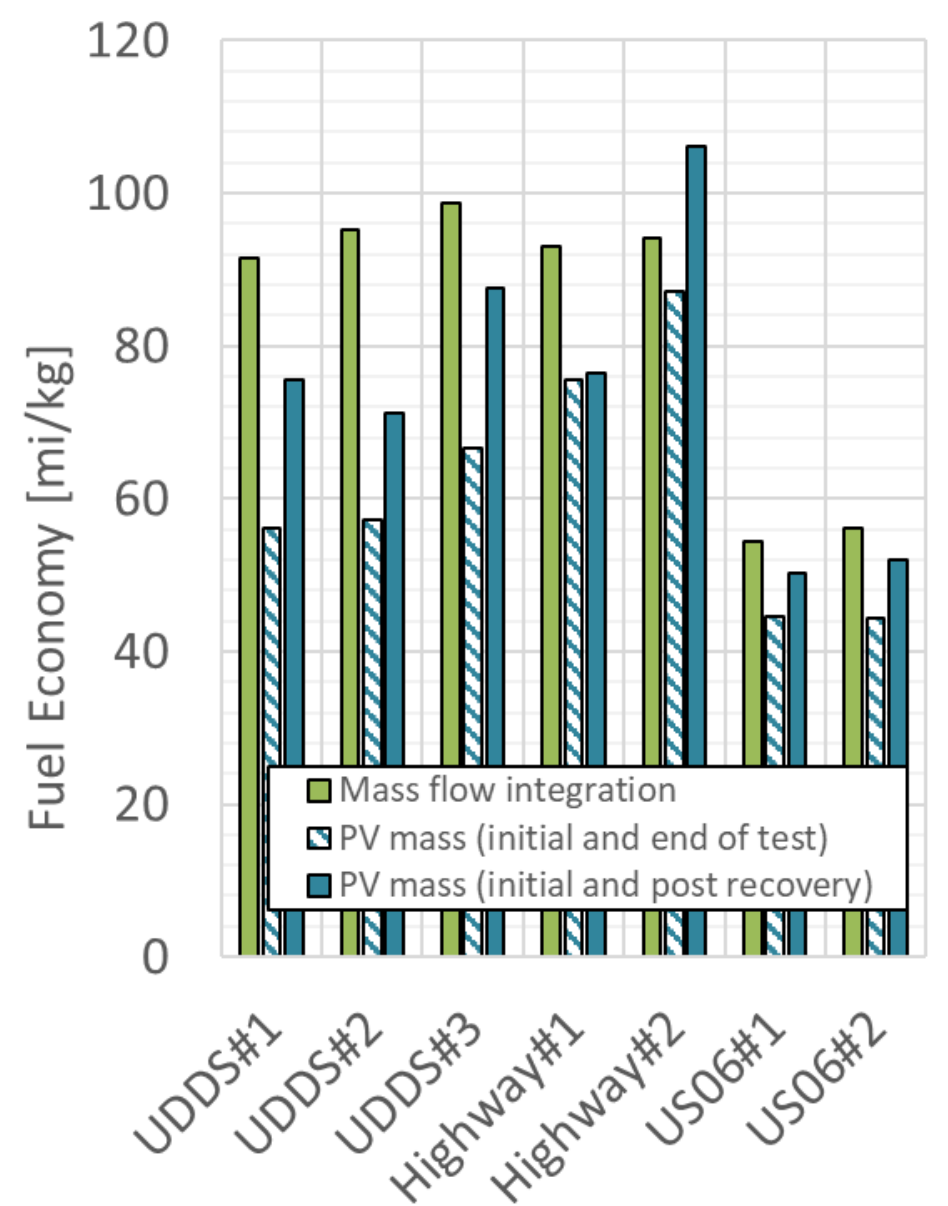

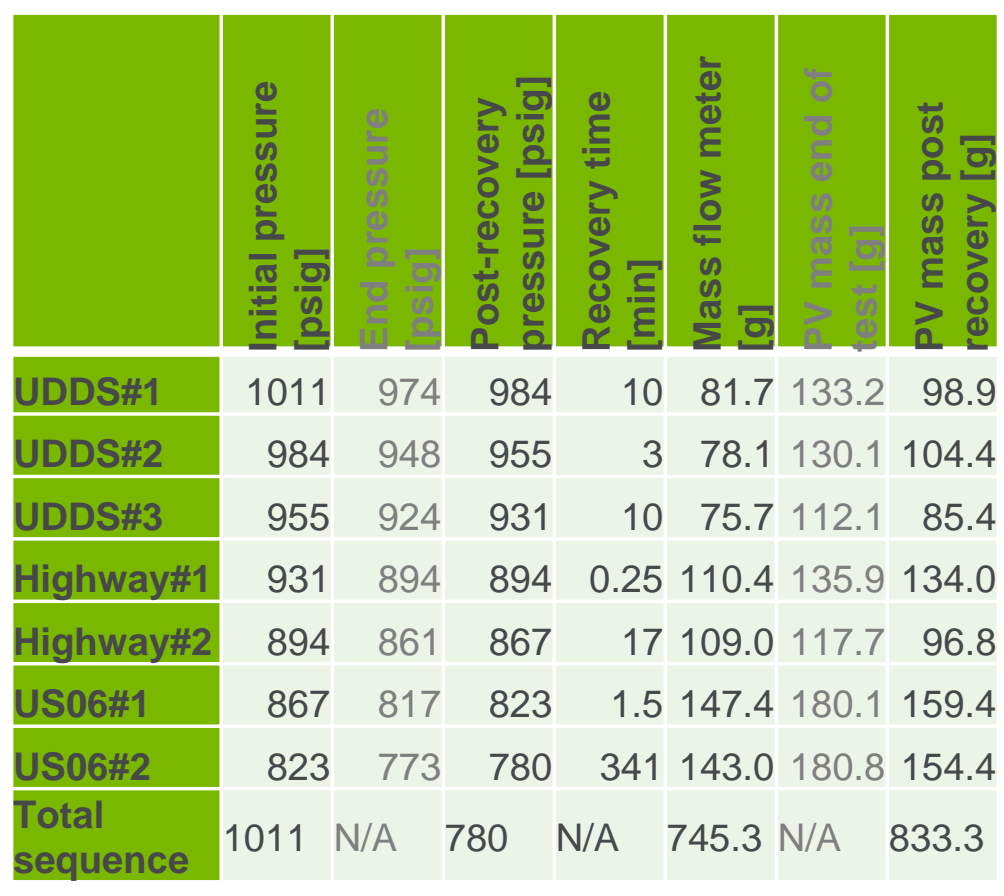

The hydrogen consumed based on the ideal gas law is $12 \%$ high than the integrated hydrogen mass flow meter.

Note: To truly compare the two measurement methods, it would require to have a temperature controlled enclosure for the hydrogen storage and wait until the gas and cylinders stabilized at the enclosure temperature after the test before calculating the mass of hydrogen post test. The volume of high pressure piping should be known as well. 


\section{FUEL CELL SYSTEM OVERVIEW}

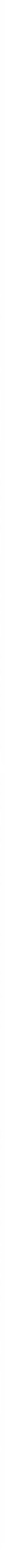




\section{FUEL CELL POLARIZATION CURVE}
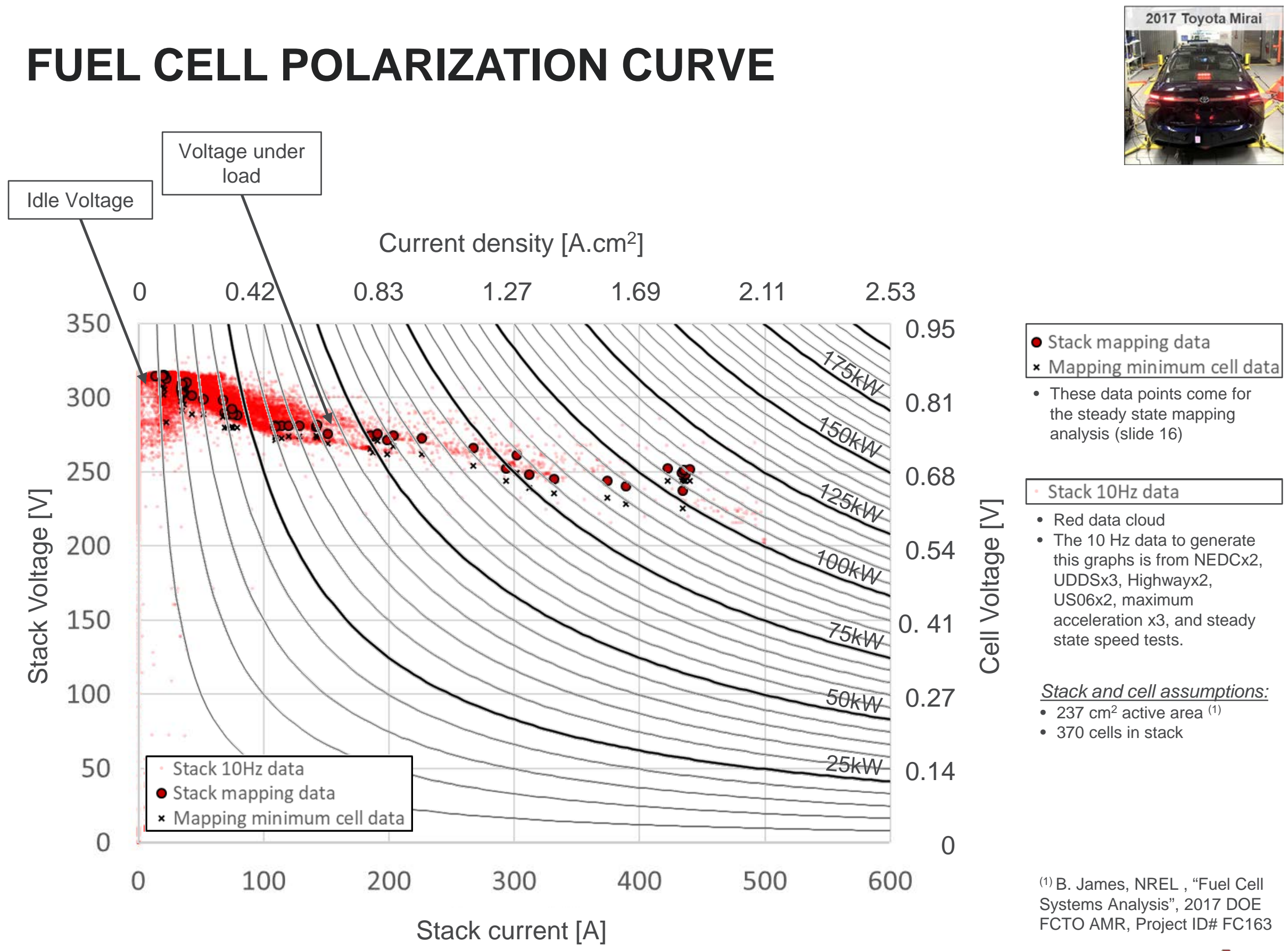

(1) B. James, NREL , "Fuel Cell Systems Analysis", 2017 DOE FCTO AMR, Project ID\# FC163

\section{Argonne

- Stack mapping data

× Mapping minimum cell data

- These data points come for the steady state mapping analysis (slide 16)

\section{- Stack $10 \mathrm{~Hz}$ data}

Red data cloud UDDSx3, Highwayx2, US06x2, maximum acceleration $\mathrm{x} 3$, and steady state speed tests.

Stack and cell assumptions: - $237 \mathrm{~cm}^{2}$ active area (1)

- 370 cells in stack 


\section{FUEL CELL STACK OPERATING PARAMETERS AND HUMIDIFICATION CONTROL MECHANISMS}

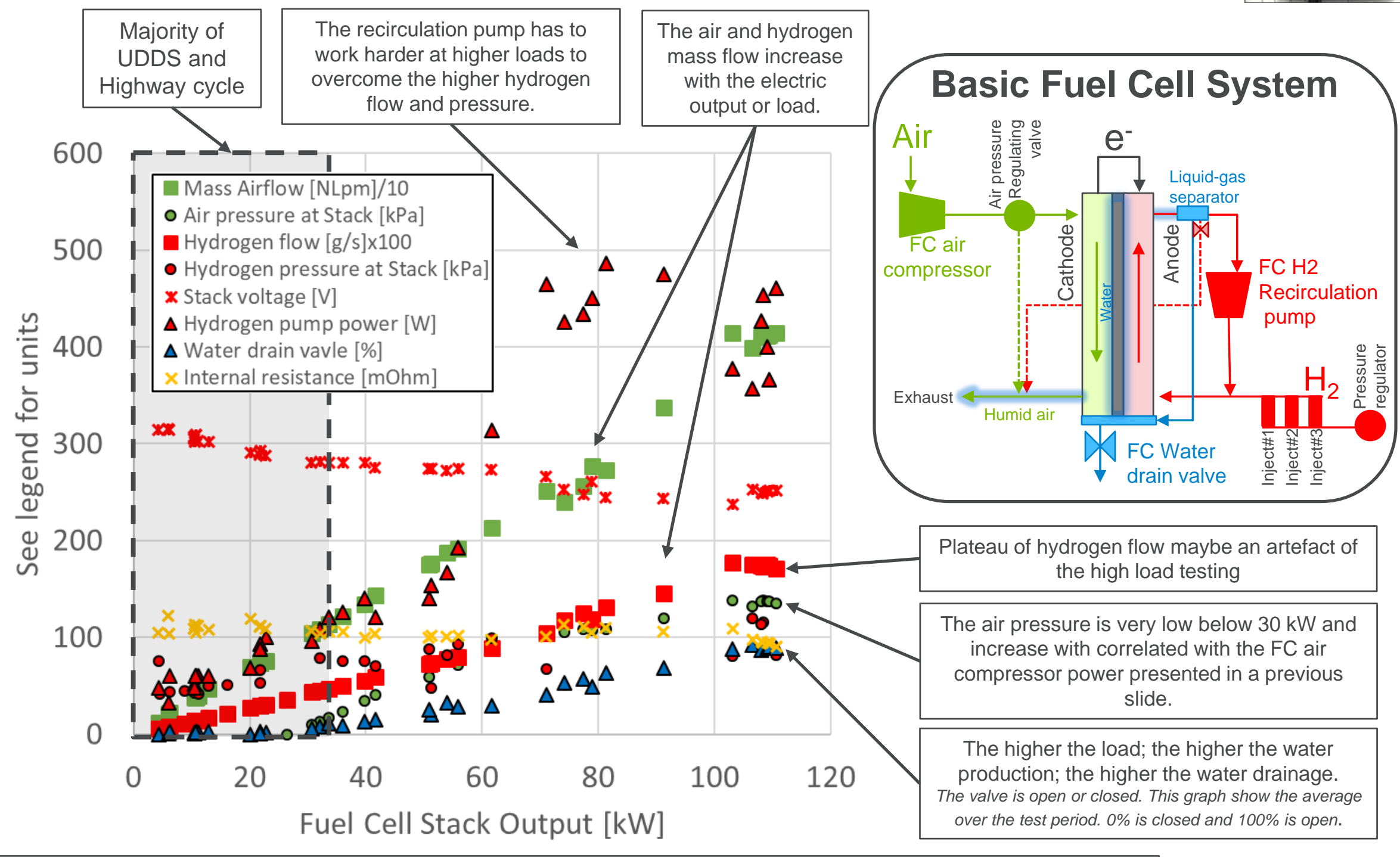




\section{FUEL CELL STACK OPERATING PARAMETERS AND HUMIDIFICATION CONTROL MECHANISMS}

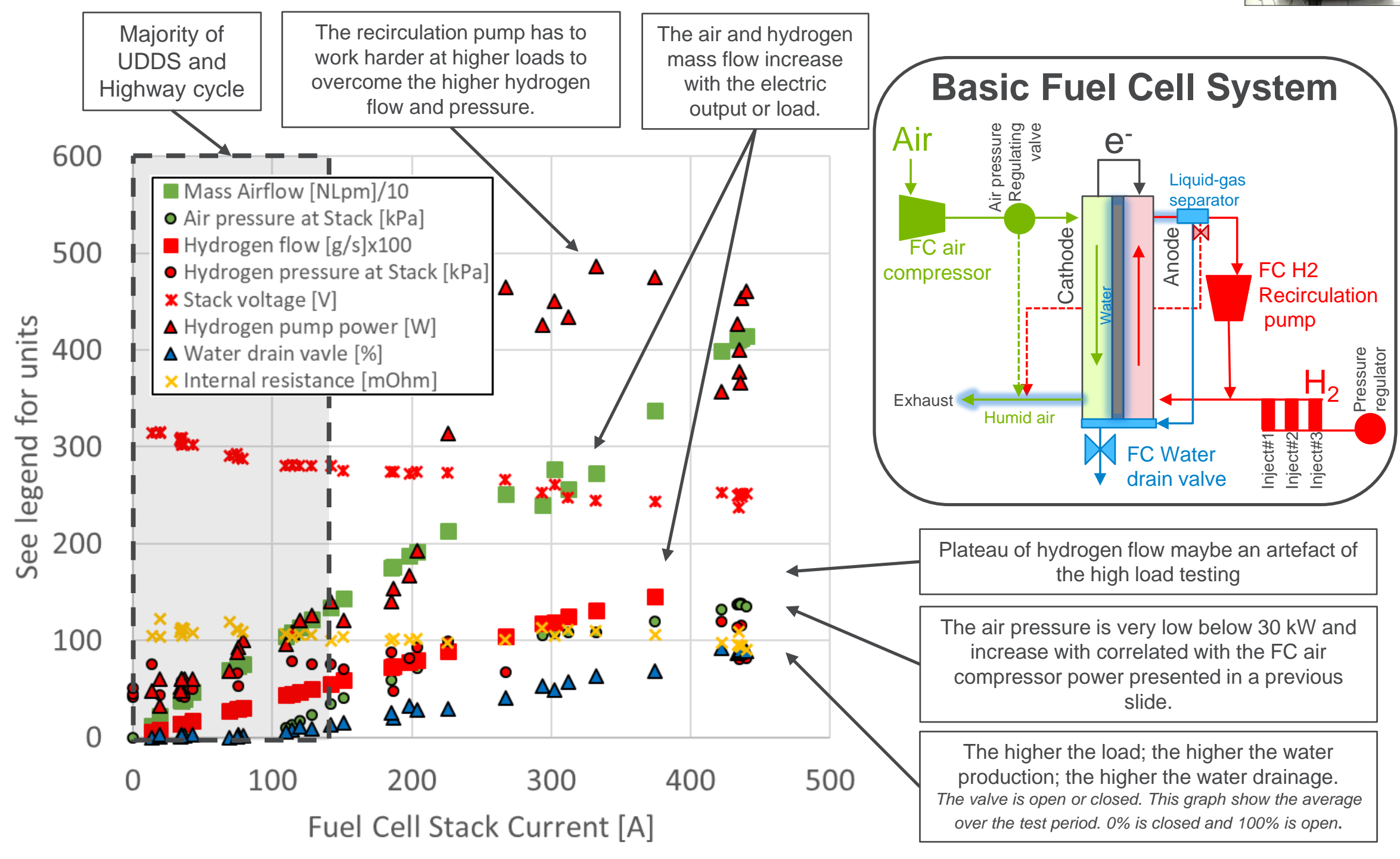




\section{FUEL CELL IDLE OPERATION ON DRIVE CYCLE \\ FUEL CELL IDLE OPERATION ON DRIVE CYCLE}

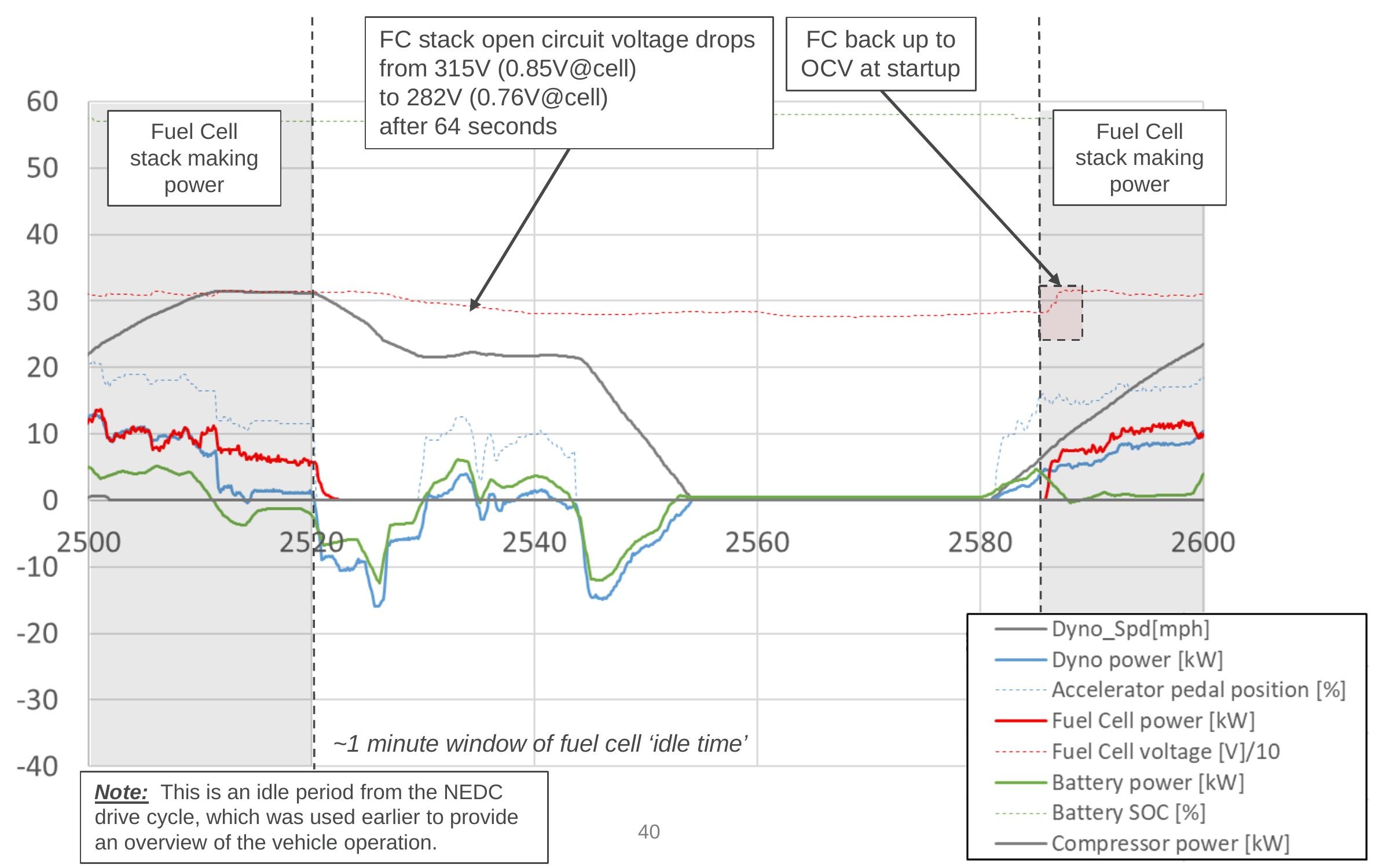




\section{FUEL CELL IDLE OPERATION ON DRIVE CYCLE}

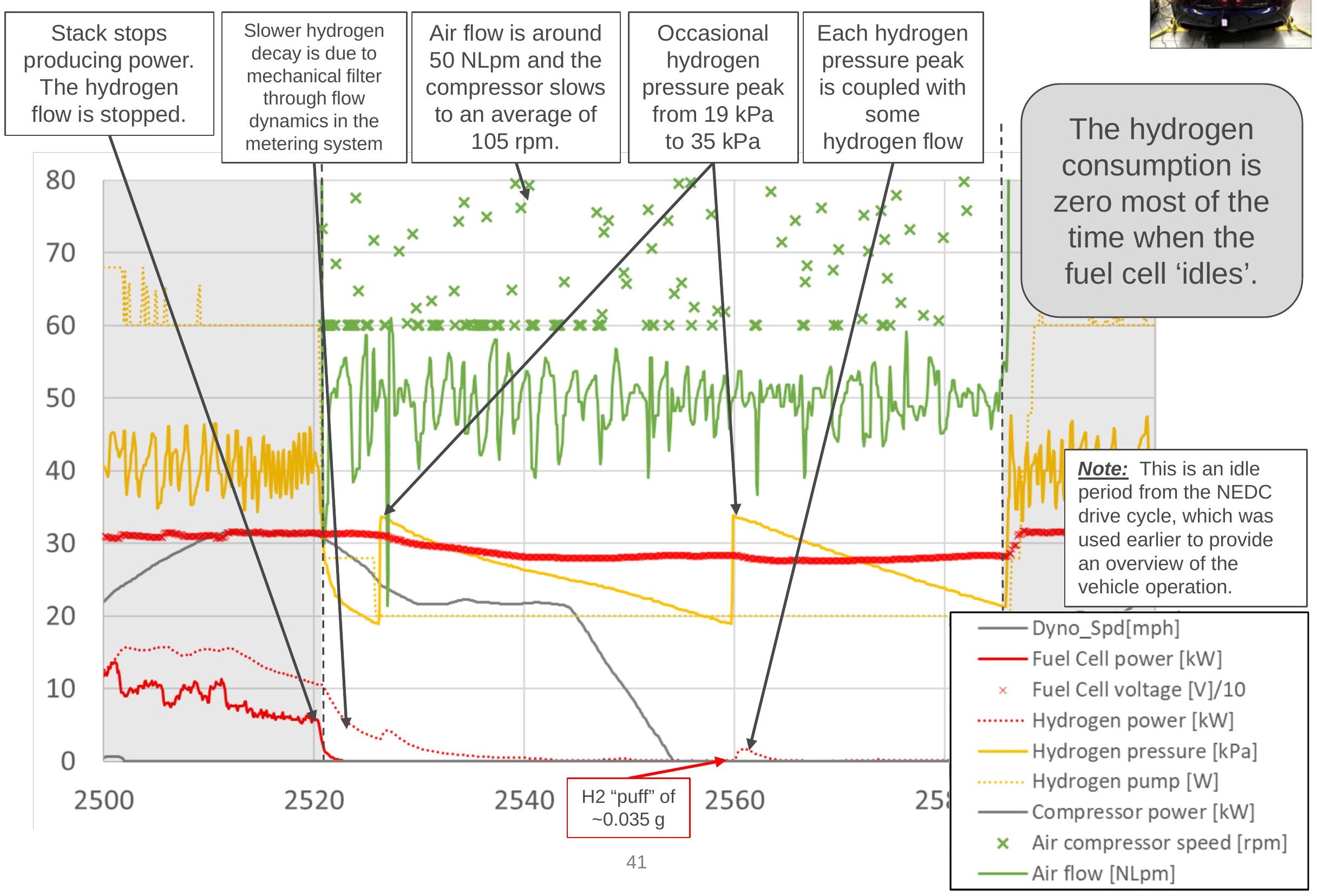




\section{SPECIAL 1 HOUR IDLE TEST TO QUANTIFY THE IDLE HYDROGEN CONSUMPTION}

First 505 second of UDDS cycle (Phase1) to warm up the powertrain

\section{0}

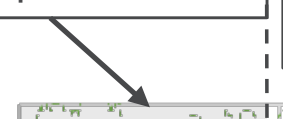

Vehicle stopped, transmission in park, ignition ON. Scenario: waiting in parking lot.

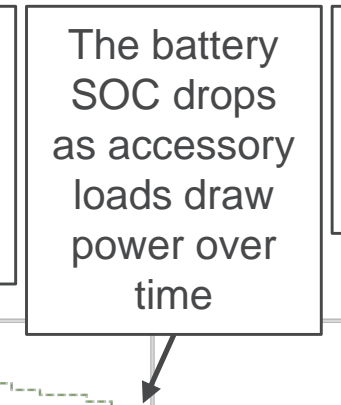

Low SOC
triggers
restart of FC
system

FC system recharge the battery at $5 \sim 6 \mathrm{~kW}$

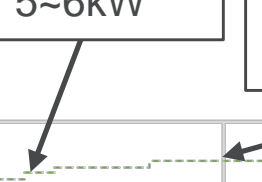

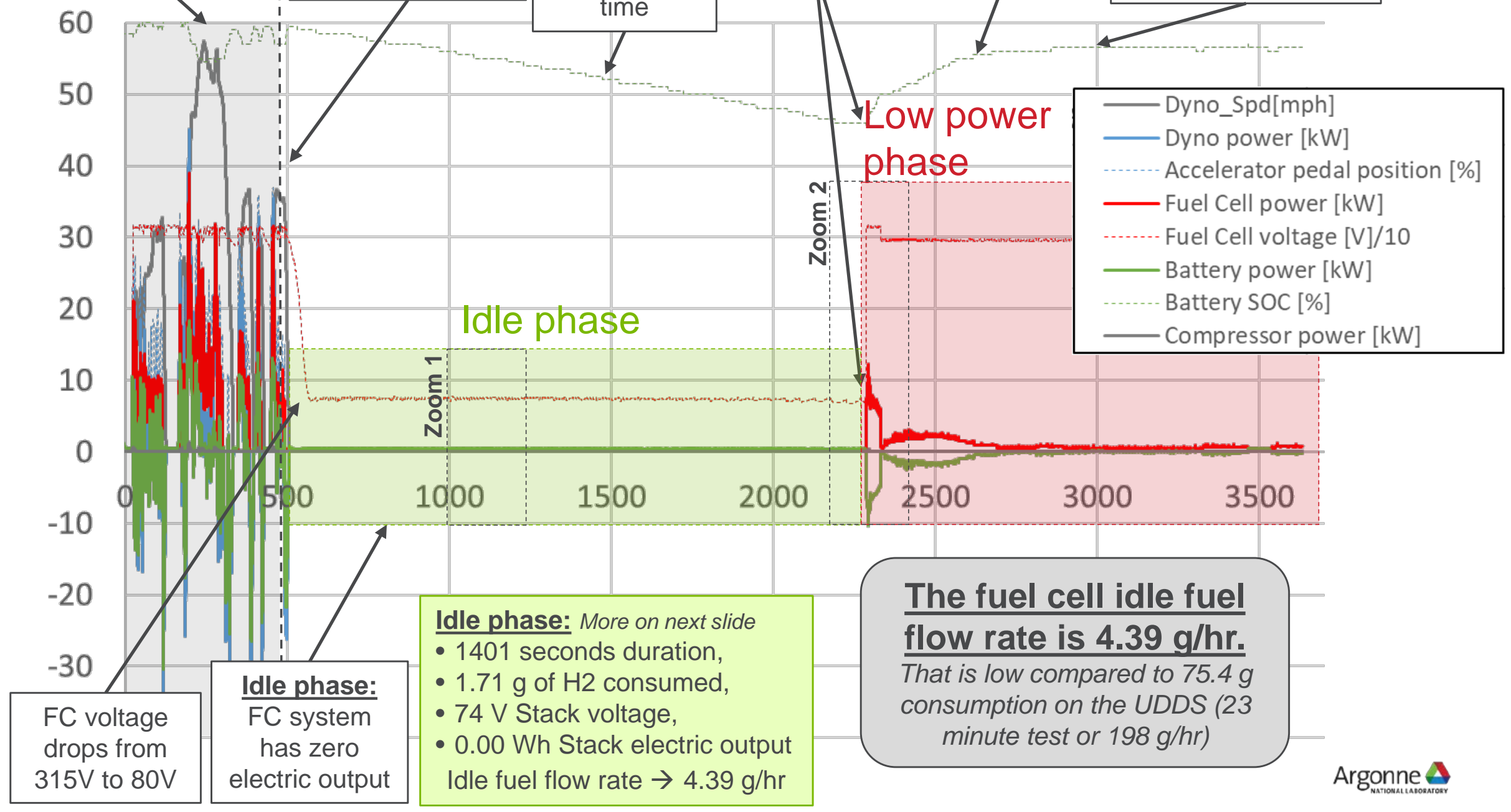




\section{MORE DETAILS ON SPECIAL 1 HOUR IDLE TEST}

\begin{tabular}{|} 
Hydrogen \\
pressure bumps \\
from $20 \mathrm{kPa}$ to \\
$35 \mathrm{kPa}$ every \\
40 seconds
\end{tabular}

\begin{tabular}{|} 
Hydrogen pumps \\
step up from \\
$20 \mathrm{~W}$ to $60 \mathrm{~W}$ for \\
$10 \sim 12$ second \\
every 5 minutes
\end{tabular}

\begin{tabular}{|} 
Air flow steps up \\
from 50 to 200 \\
NLpm for 4 second \\
every 3 minutes
\end{tabular}

80

70

60

50 Zoom 1 in idle phase
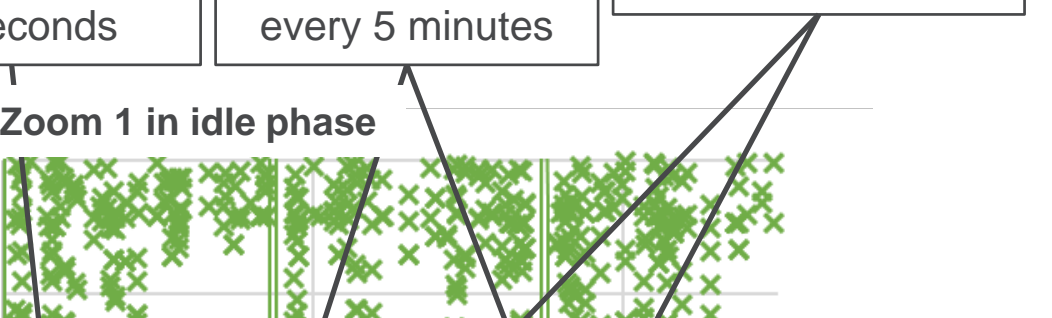

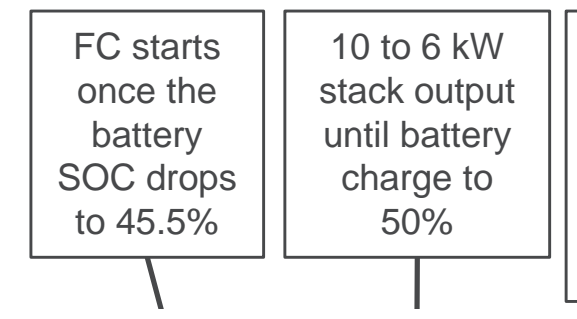

1 to $2 \mathrm{~kW}$ stack output with fuel flow pulsing and it appear that the stack is air starved (compressor speed $660 \mathrm{rpm}$ ). 4 minutes later the FC settles to $500 \mathrm{~W}$ to sustain accessory loads.

Zoom 2 at start of low power phase

1.

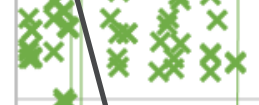

40

30

20

10
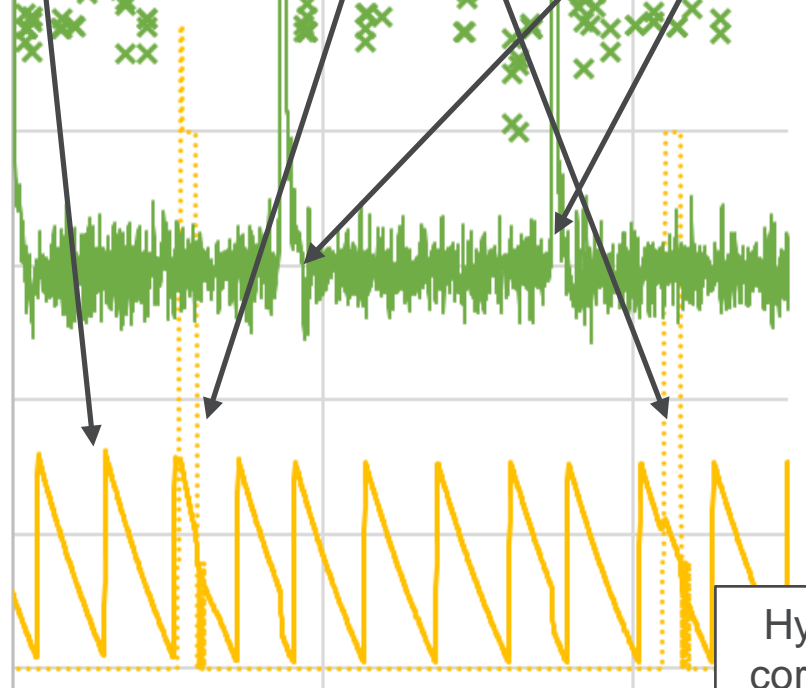

0

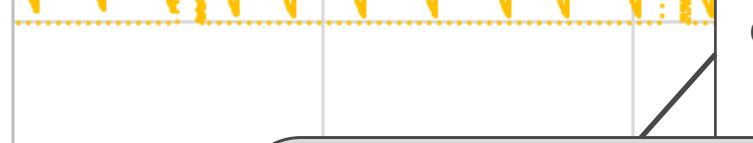

drogen puffs corresponding to

hydrogen

nressure bumps

During the idle phases the FC system is

1000 starved of hydrogen to maintain a low open circuit voltage.
60

50

40

30

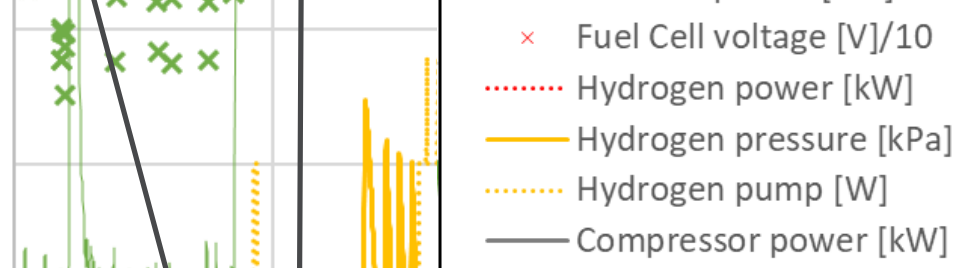

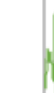

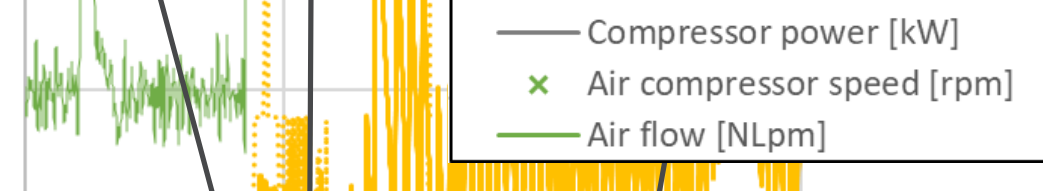

20

10
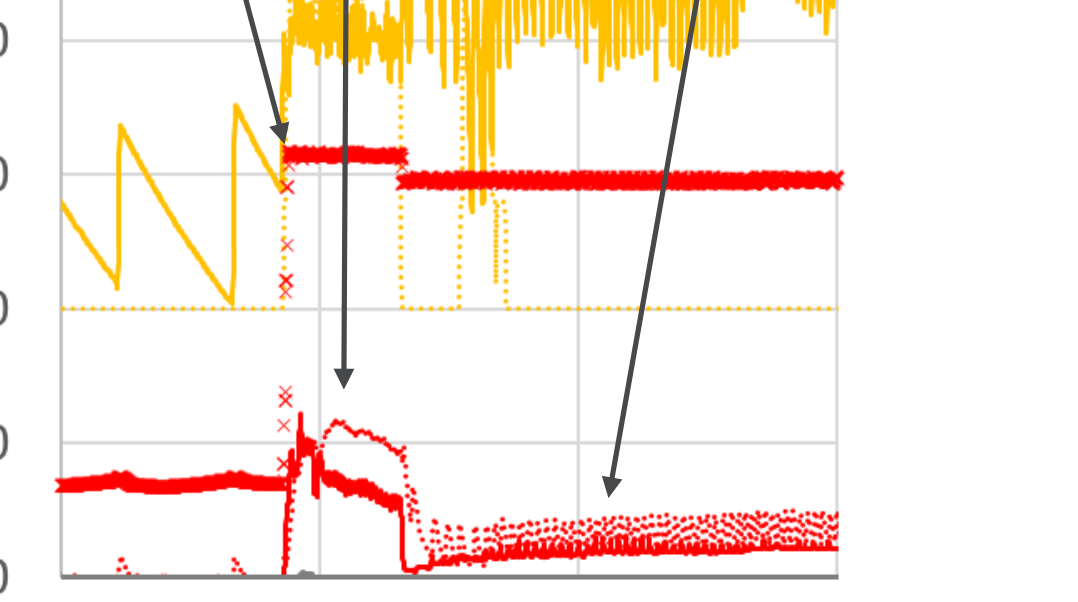

2200

2300

2400

2500 


\section{MAXIMUM POWER TESTING ON A 25\% GRADE AT 72F}

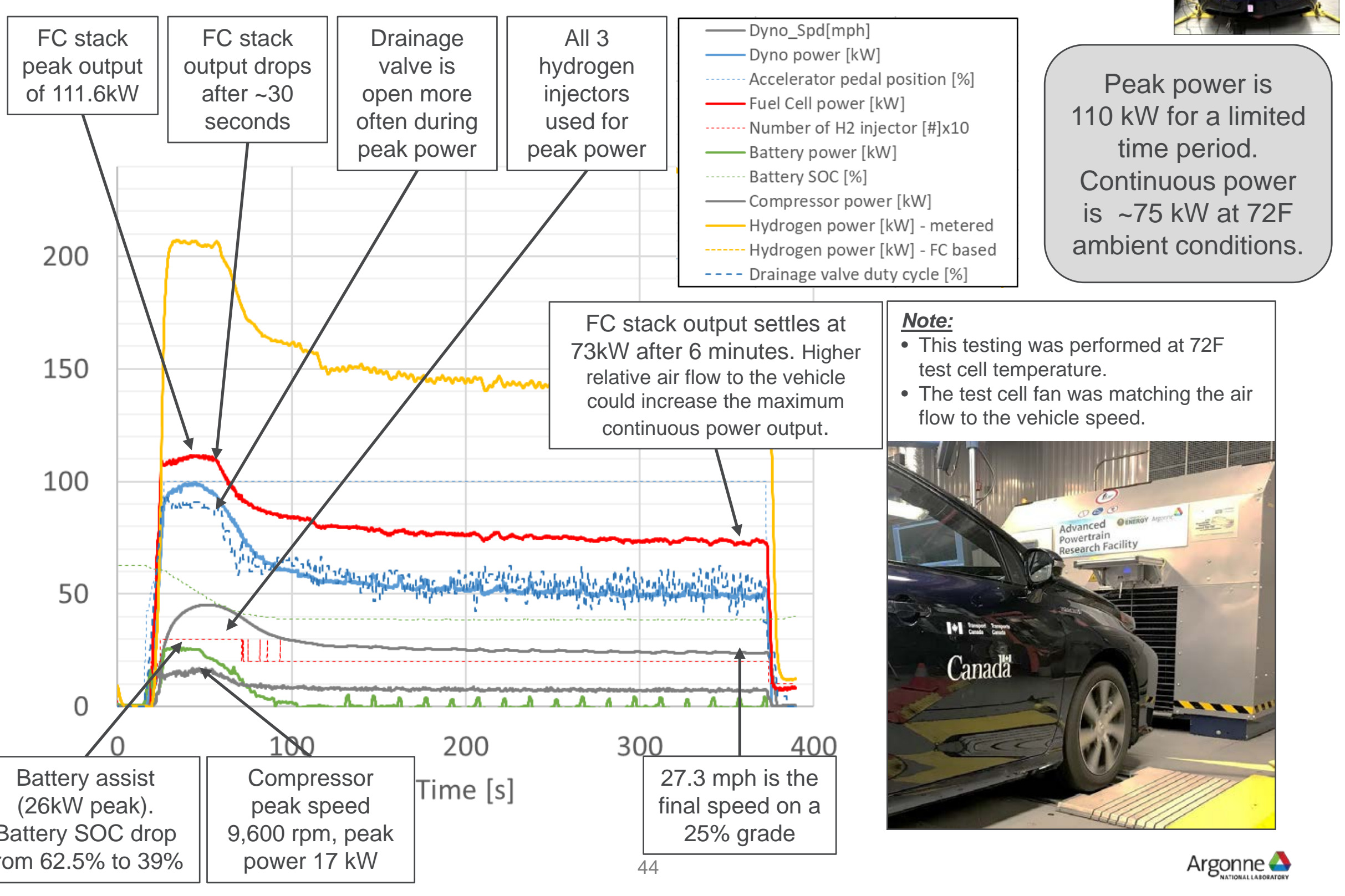




\section{MAXIMUM POWER TESTING ON A 25\% GRADE AT 72F - NO FUEL STARVATION}
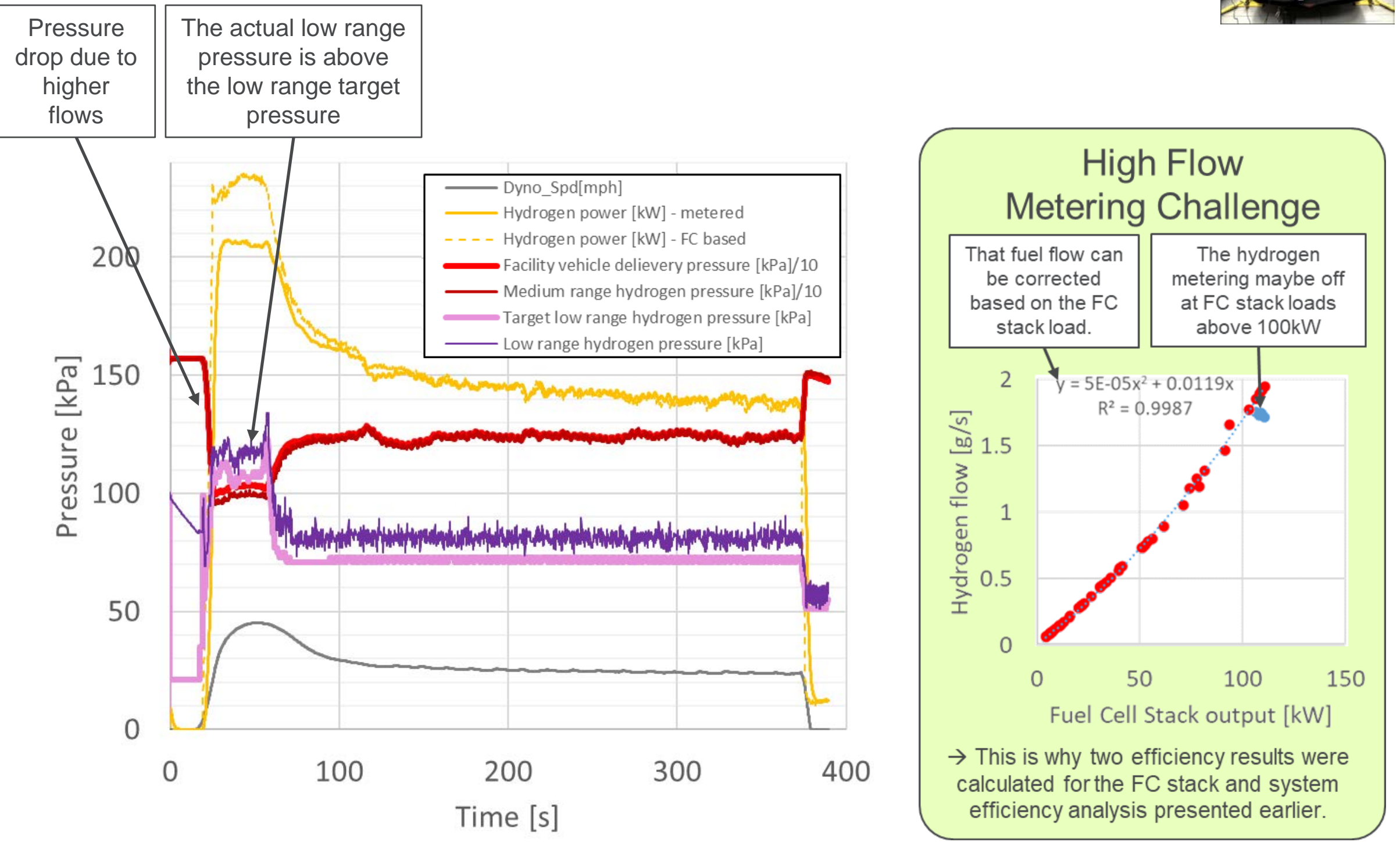


\section{MAXIMUM POWER TESTING ON A 25\% GRADE AT 72F - THERMAL CONDITIONS}

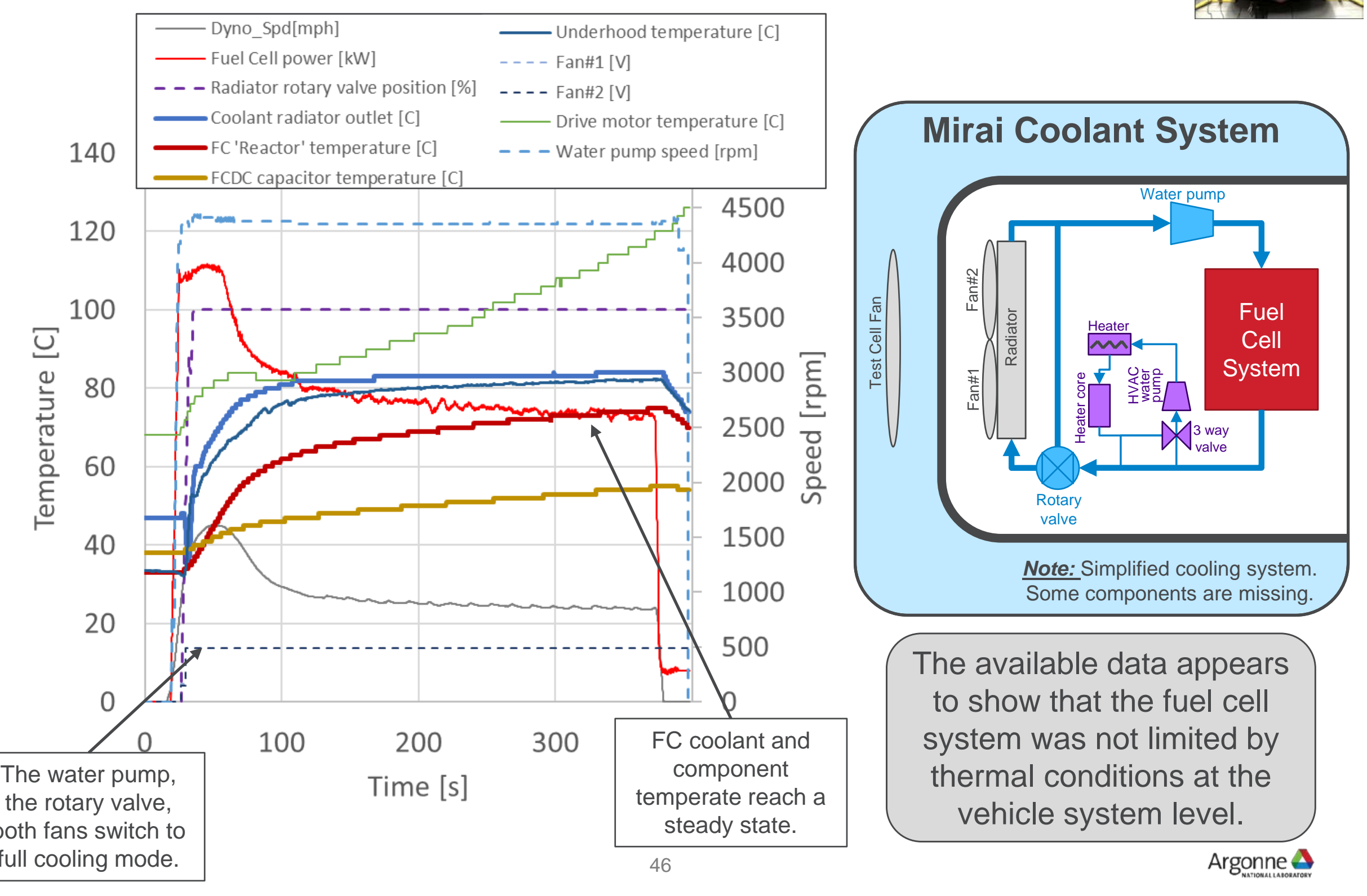




\section{REPEATED MAXIMUM ACCELERATIONS TO 80 MPH AT 72F AMBIENT TEMPERATURE}

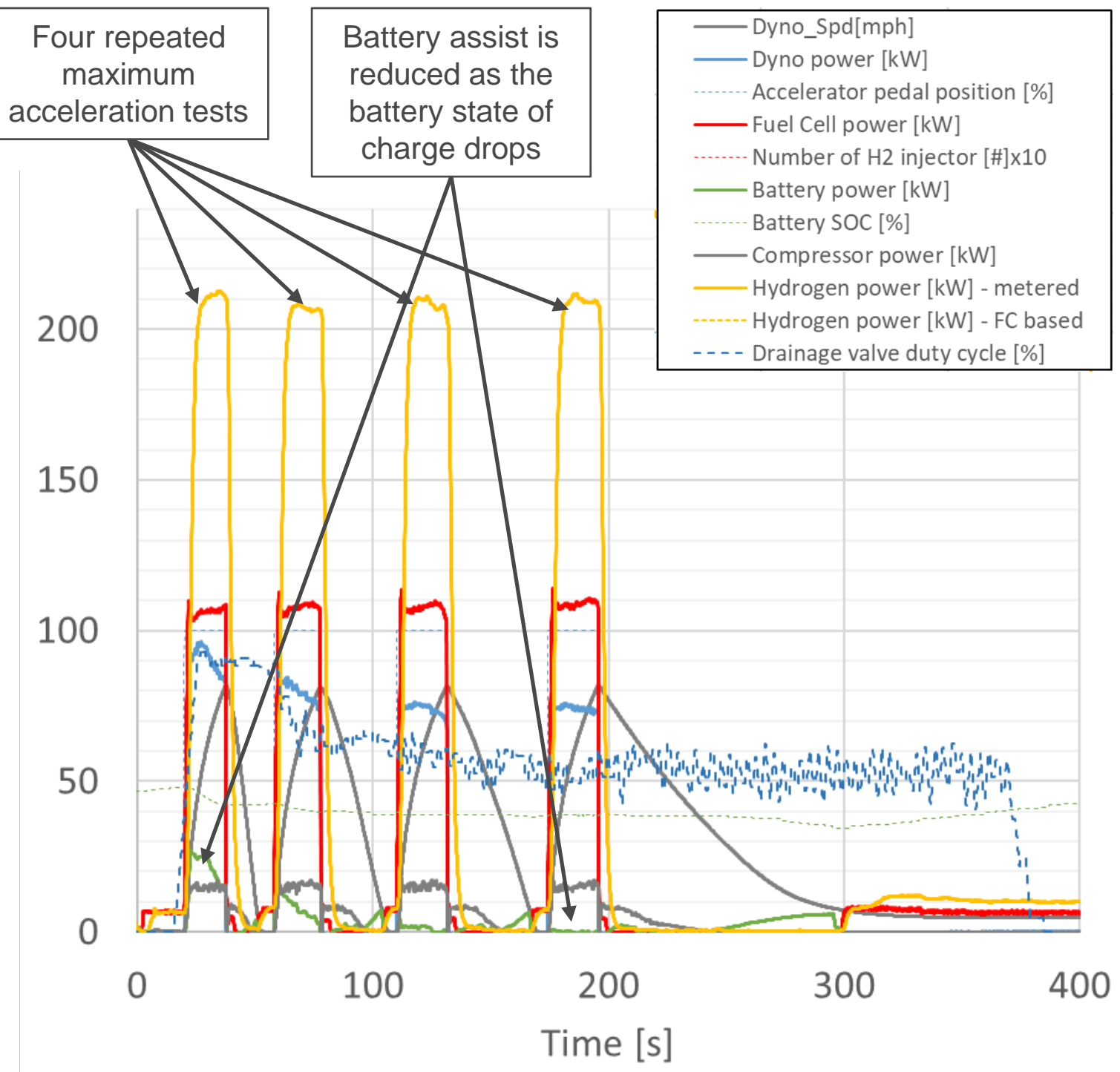

\begin{tabular}{|c|c|c|c|}
\hline Run & $\begin{array}{l}\mathbf{0 - 8 0} \text { mph } \\
{[\mathrm{s}]}\end{array}$ & $\begin{array}{l}\text { Peak } \\
\text { Stack } \\
{[\mathrm{kW}]}\end{array}$ & $\begin{array}{l}\text { Average } \\
\text { Stack } \\
{[\mathrm{kW}]}\end{array}$ \\
\hline 1 & 16.7 & 109.9 & 100.6 \\
\hline 2 & 18.7 & 112.6 & 103.0 \\
\hline 3 & 20.2 & 113.5 & 103.8 \\
\hline 4 & 20.3 & 114.0 & 104.6 \\
\hline
\end{tabular}

The fuel cell system reliably and consistently produces peak power for repeat accelerations runs. 


\section{IMPACT OF TEMPERATURES: OF, 20F, 72F AND 95F+850W/M ${ }^{2}$}

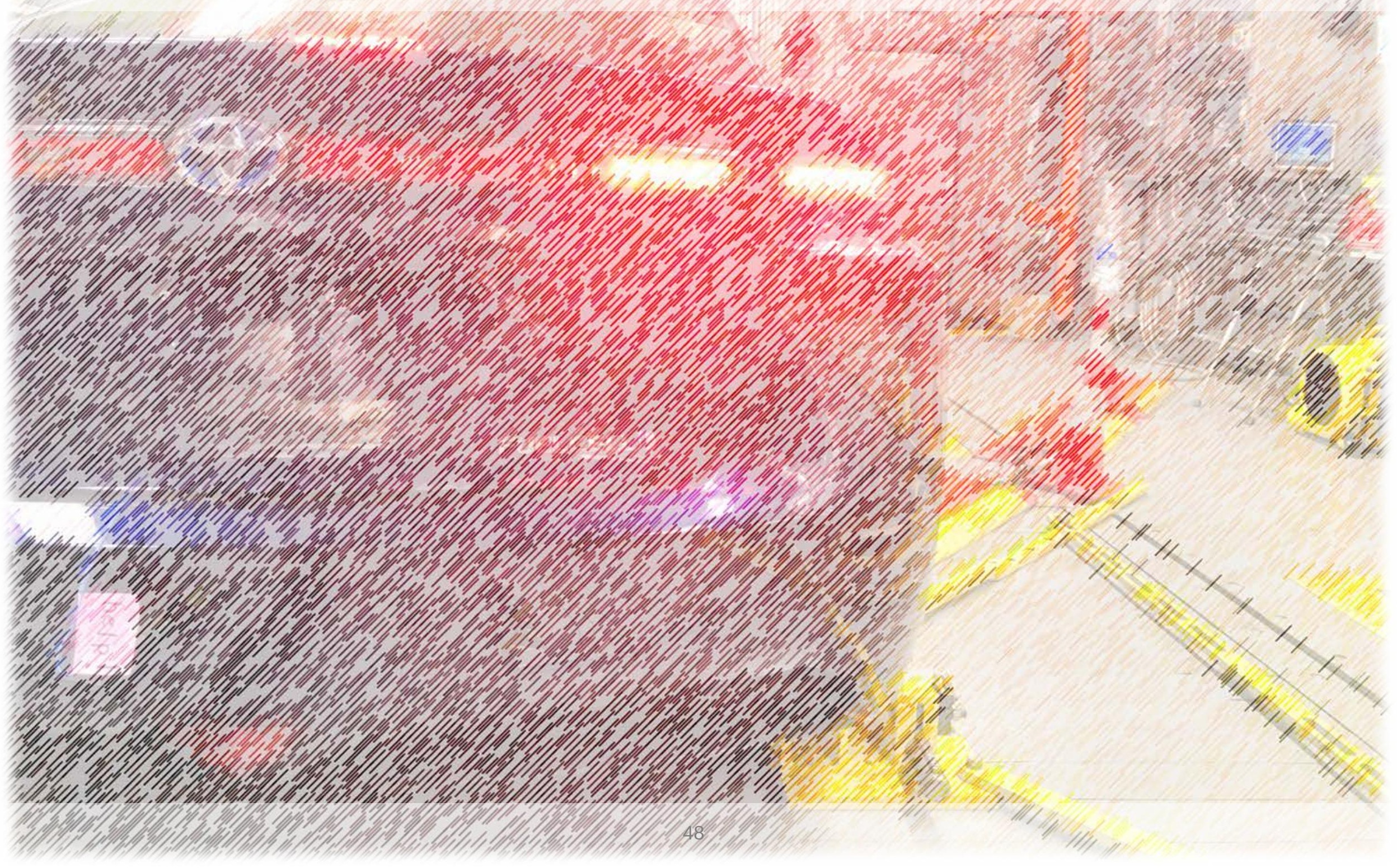




\section{TESTING ACROSS A RANGE OF TEMPERATURES}

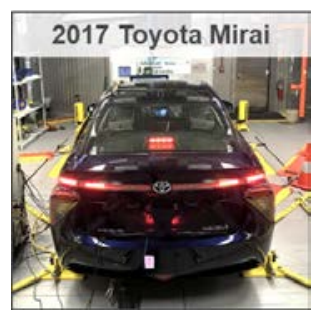

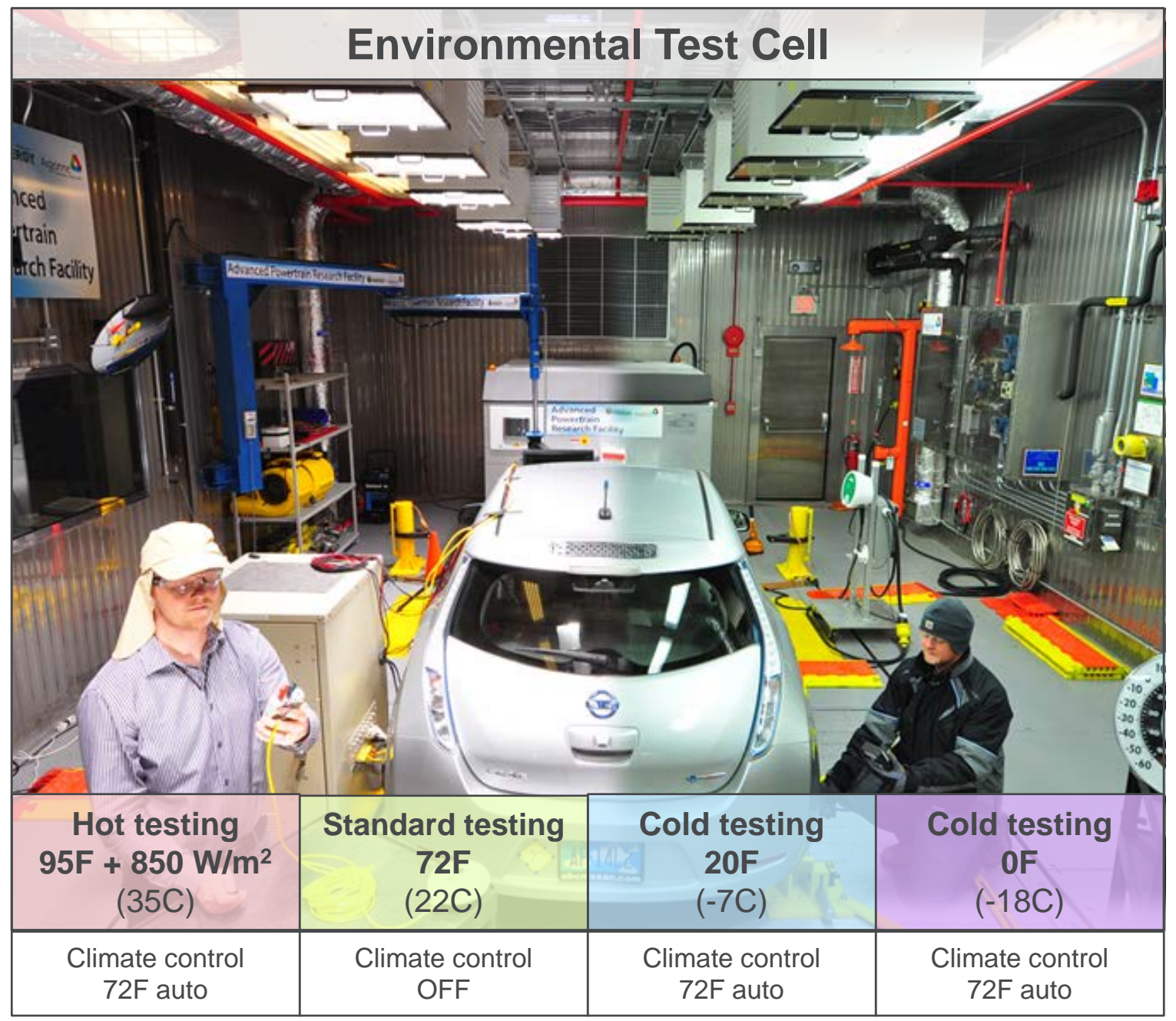

\section{Thermal testing}

- The hood is closed in all cases

- The facility fan blows air dynamically across the front of the car at the same speed as the vehicle speed

- Cold start means that the vehicle was thermally 'soaked' at the target temperature for over 12 hours (typically 16 hours)

\section{Test Sequence}

- Cold start UDDS \#1 + Hot start UDDS \#2, \& UDDS \#3

- Pair of Highway cycles (except for OF)

- Pair of USO6 cycles (expect for OF) 


\section{IMPACT OF AMBIENT TEMPERATURE AND CLIMATE CONTROL ON FUEL ECONOMY}
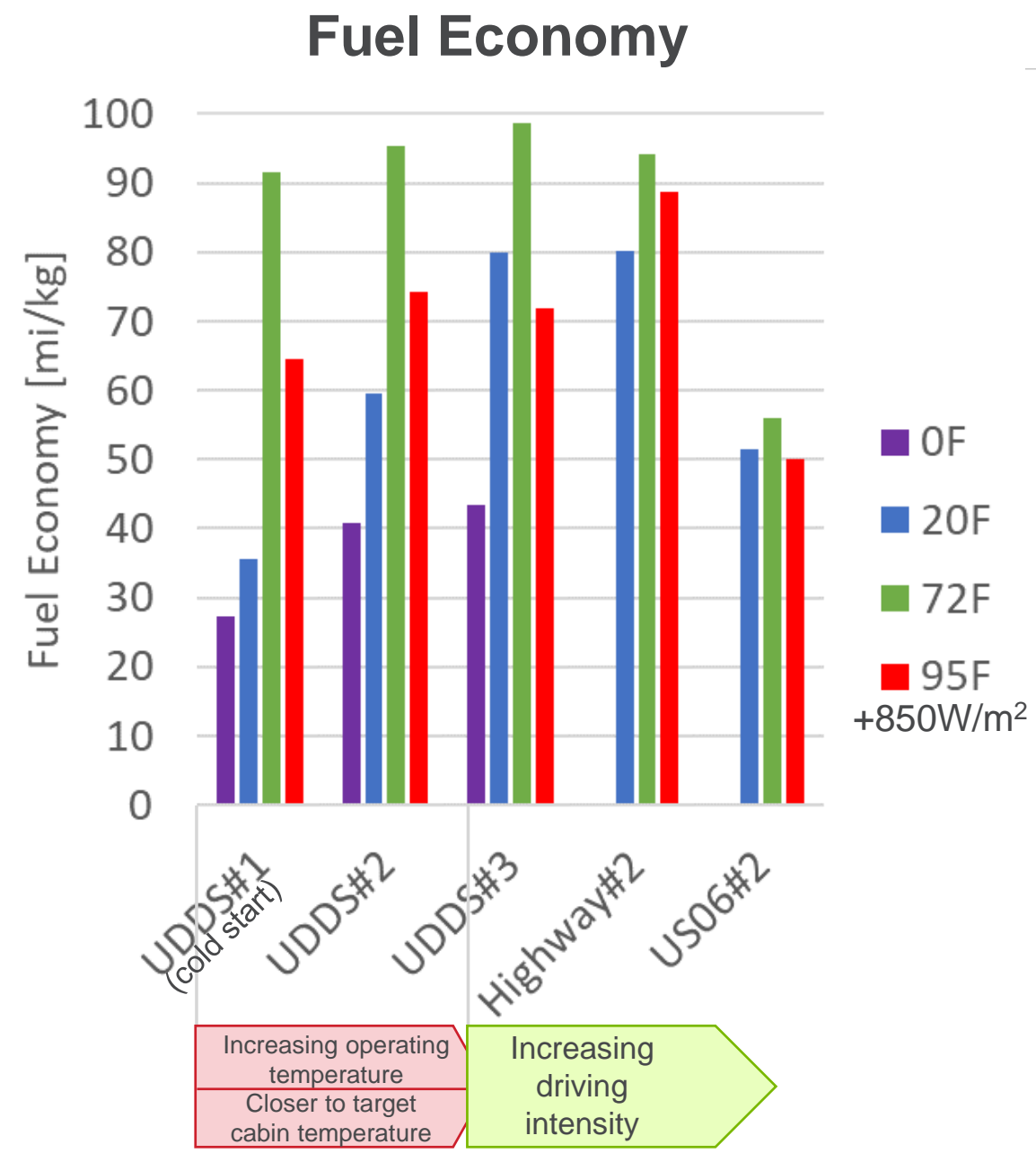

\section{Vehicle Efficiency}

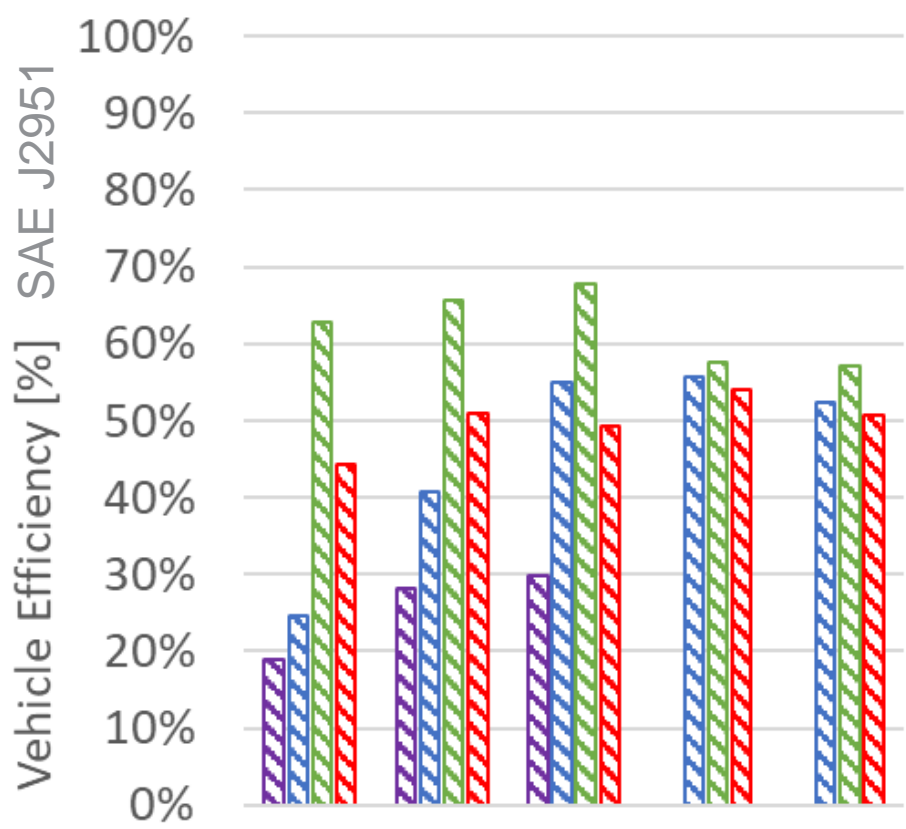

هOF

ه 20F

$\triangle 72 \mathrm{~F}$

ब95F $+850 \mathrm{~W} / \mathrm{m}^{2}$

Note: At $72 \mathrm{~F}$ the climate control was off. At $20 \mathrm{~F}$ and $95 \mathrm{~F}$ the climate control was set to $72 \mathrm{~F}$ auto. 


\section{WHERE DID THE ENERGY GO?}

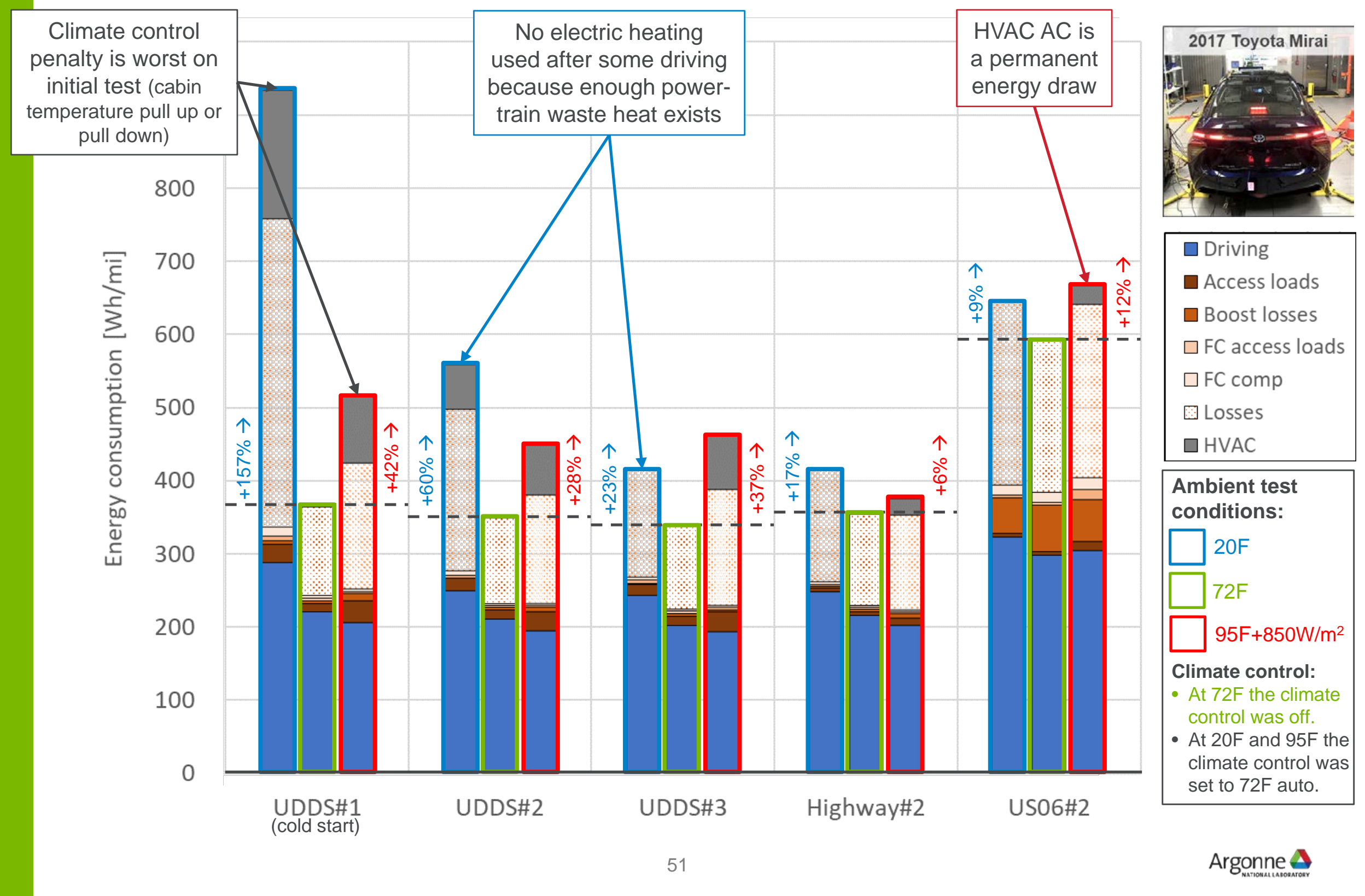




\section{COMPARING A FUEL CELL VEHICLE TO A BATTERY ELECTRIC VEHICLE ACROSS TEMPERATURES}

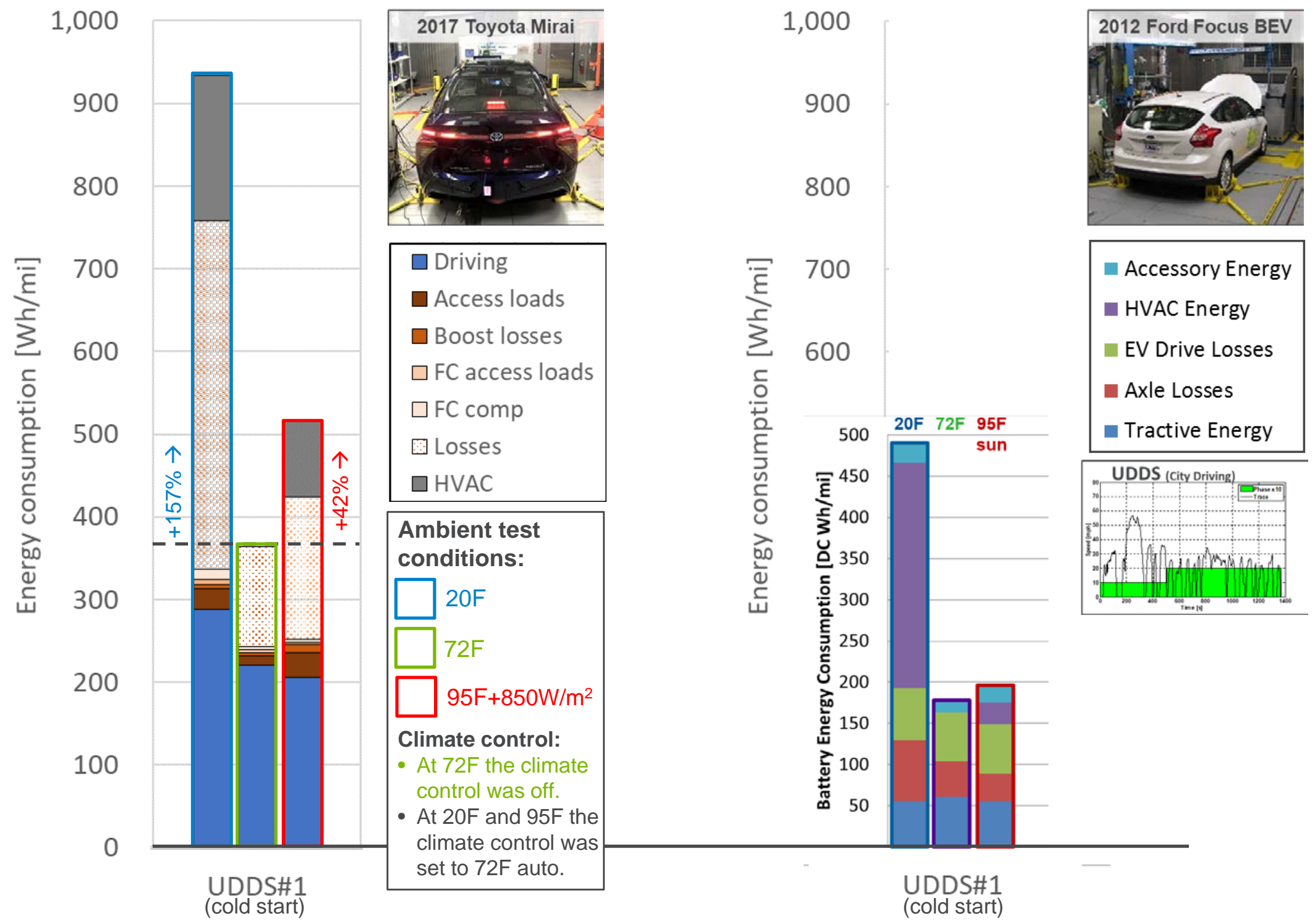




\section{UDDS DRIVE CYCLES TEST SEQUENCE AT OF, 20F AND 72F}

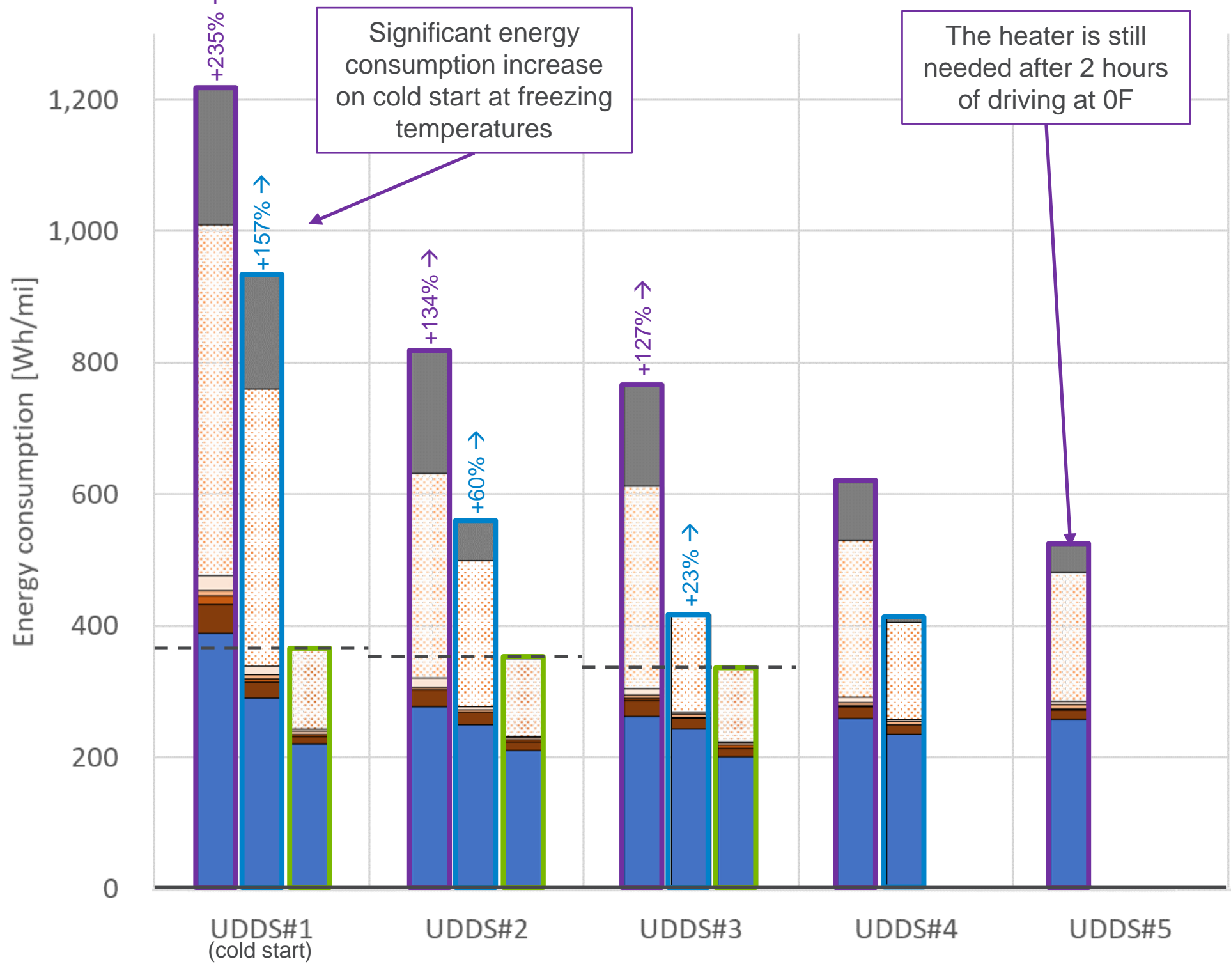




\section{FUEL CELL SYSTEM SHUTDOWN AT 72F}

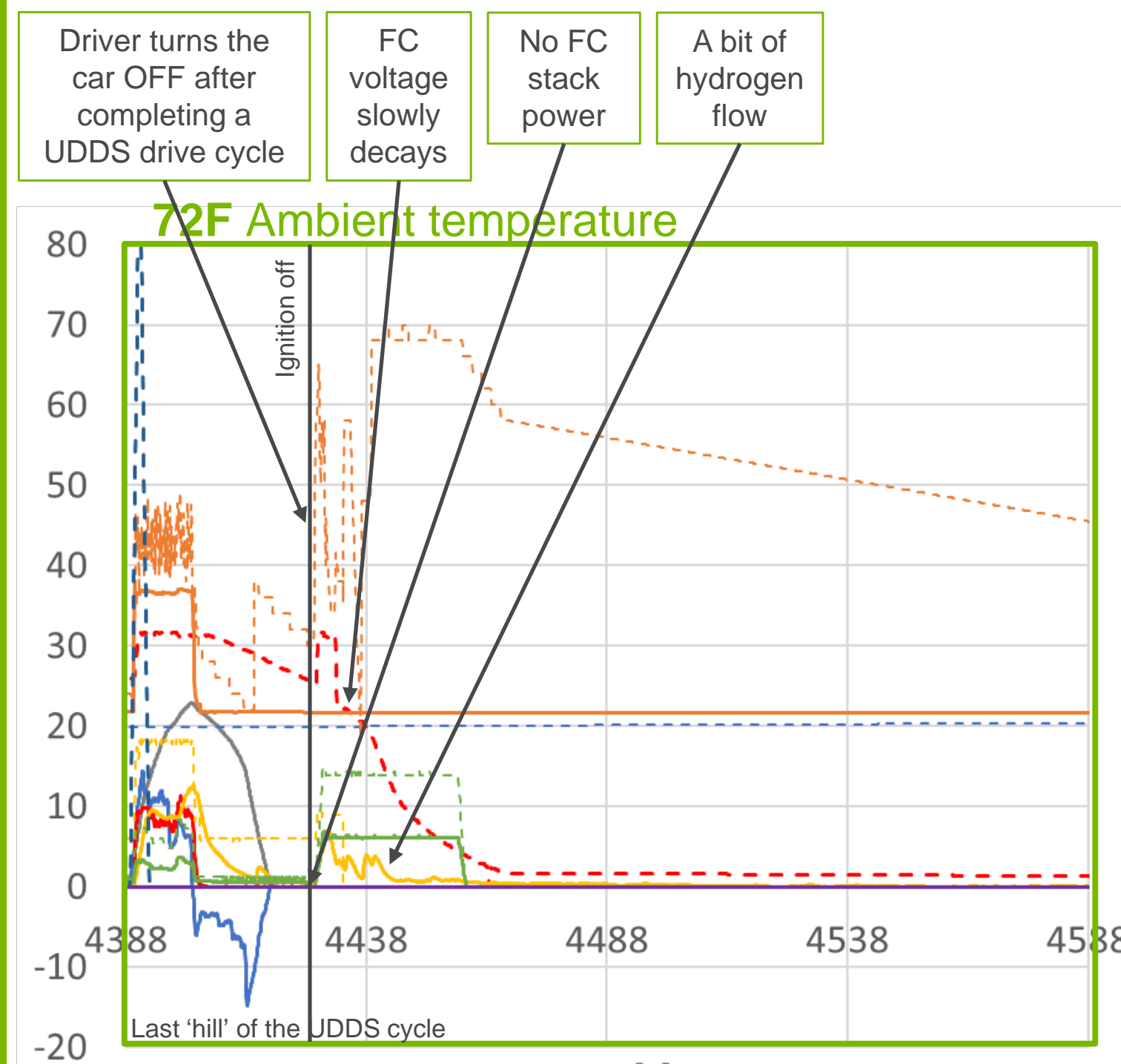

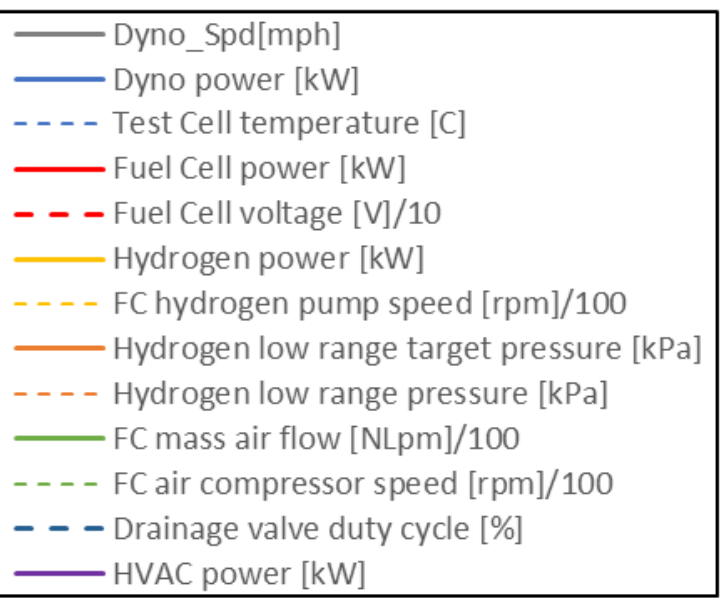

Purpose of the shut down: Leave the FC (esp PEM) in a 'good' state especially from a water management perspective.

Time $[\mathrm{s}]$ 


\section{FUEL CELL SYSTEM SHUTDOWN AT 20F}

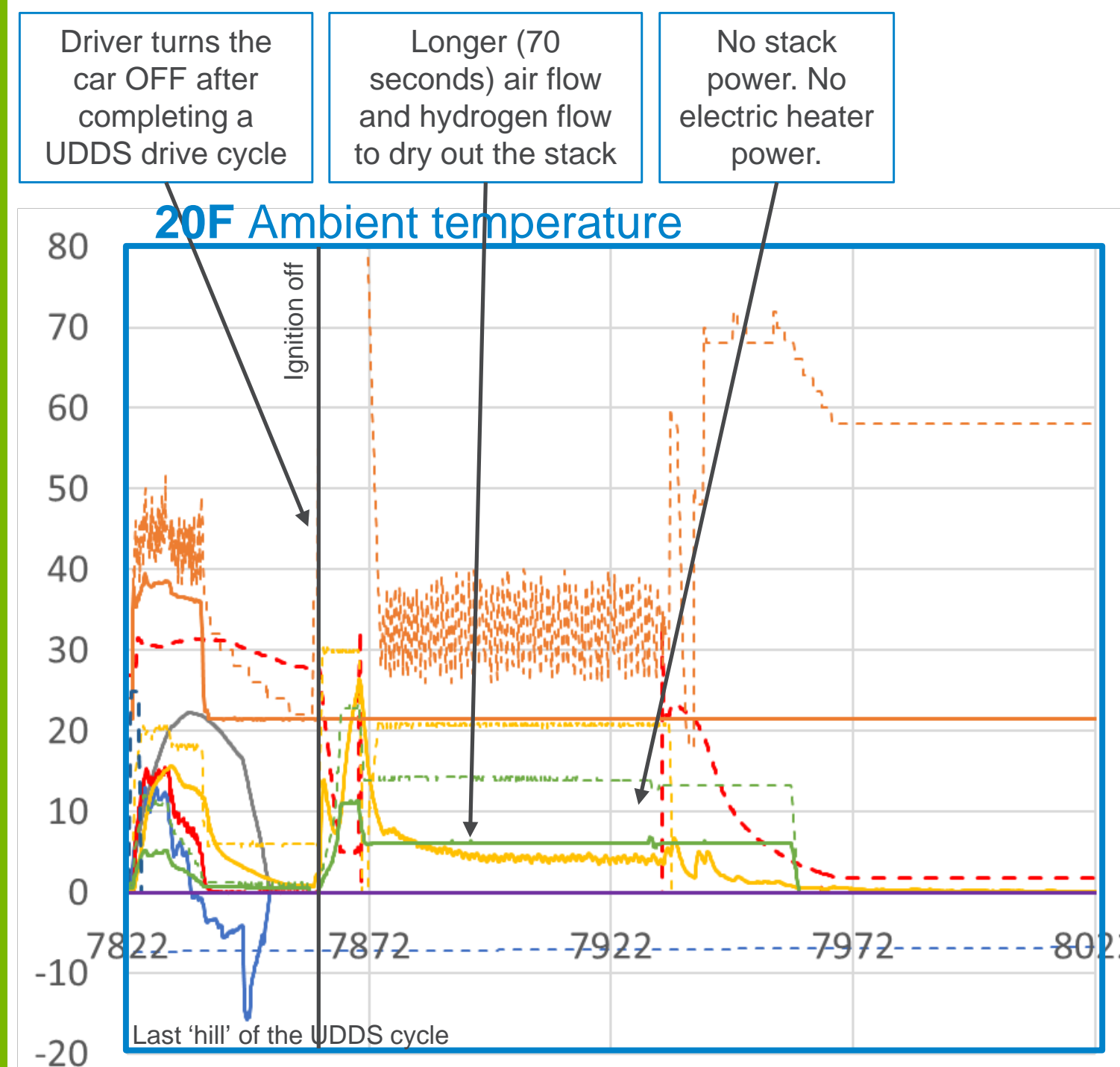

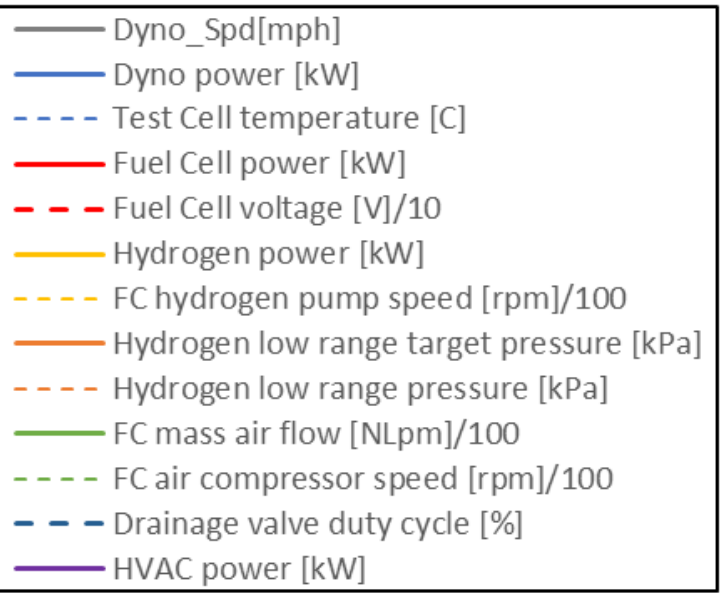

\section{Purpose of the shut down at freezing temperatures: Evacuate the water within the FC stack to prevent internal freezing.}

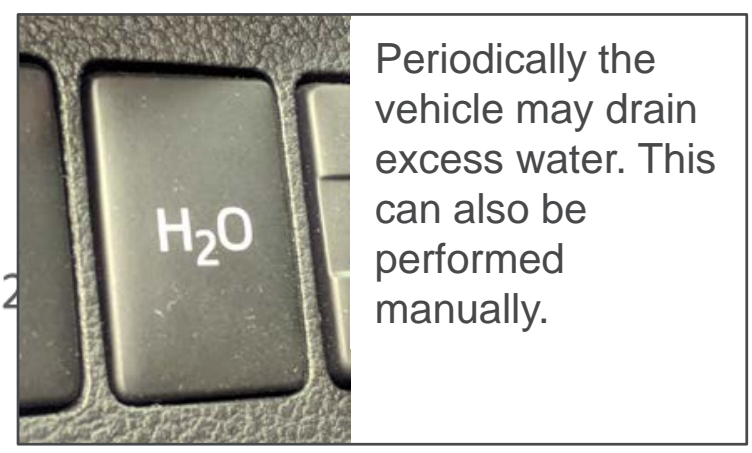

\section{Time $[s]$}

Note: When transitioning into freezing temperatures, the vehicle automatically 'wakes up' and performs a similar routine. 


\section{FUEL CELL SYSTEM SHUTDOWN AT OF}

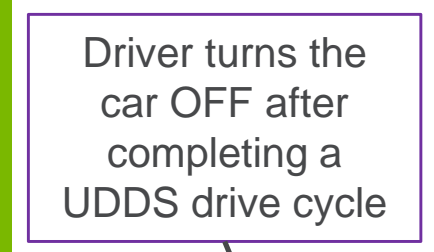

\begin{tabular}{|c|}
\hline Still 70 seconds of \\
air flow and \\
hydrogen flow to \\
dry out the stack
\end{tabular}

80 of Ambient temperature

80
70
60
50
40
30
20
10
0
10
$-10^{10}$
-20
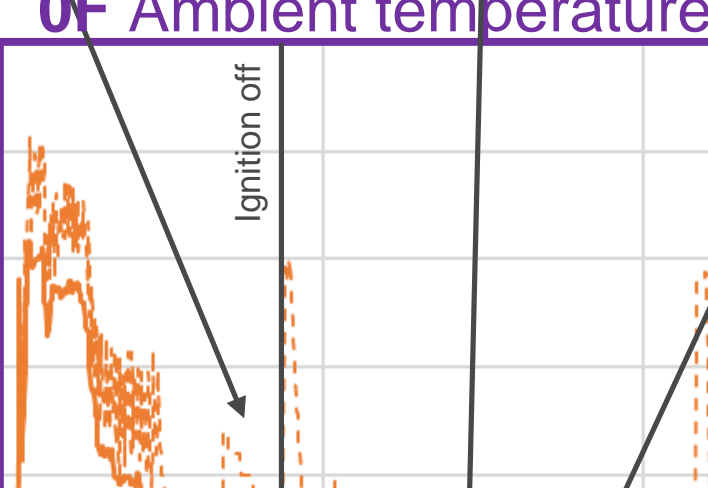

\section{Higher air \\ flow as}

compared to $20 \mathrm{~F}$
Still no stack power and no electric heater power.
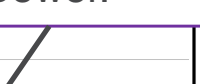

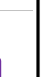

- Fuel Cell power [kw]

- - - Fuel Cell voltage [V]/10

Hydrogen power [kW]

- - - - FC hydrogen pump speed [rpm]/100

- Hydrogen low range target pressure [kPa]

- - - - Hydrogen low range pressure [kPa]

— FC mass air flow [NLpm]/100

- - - - FC air compressor speed [rpm]/100

- - - Drainage valve duty cycle [\%]

- HVAC power [kW] 


\section{FC START UP ON COLD START IN FREEZING \\ TEMPERATURES}

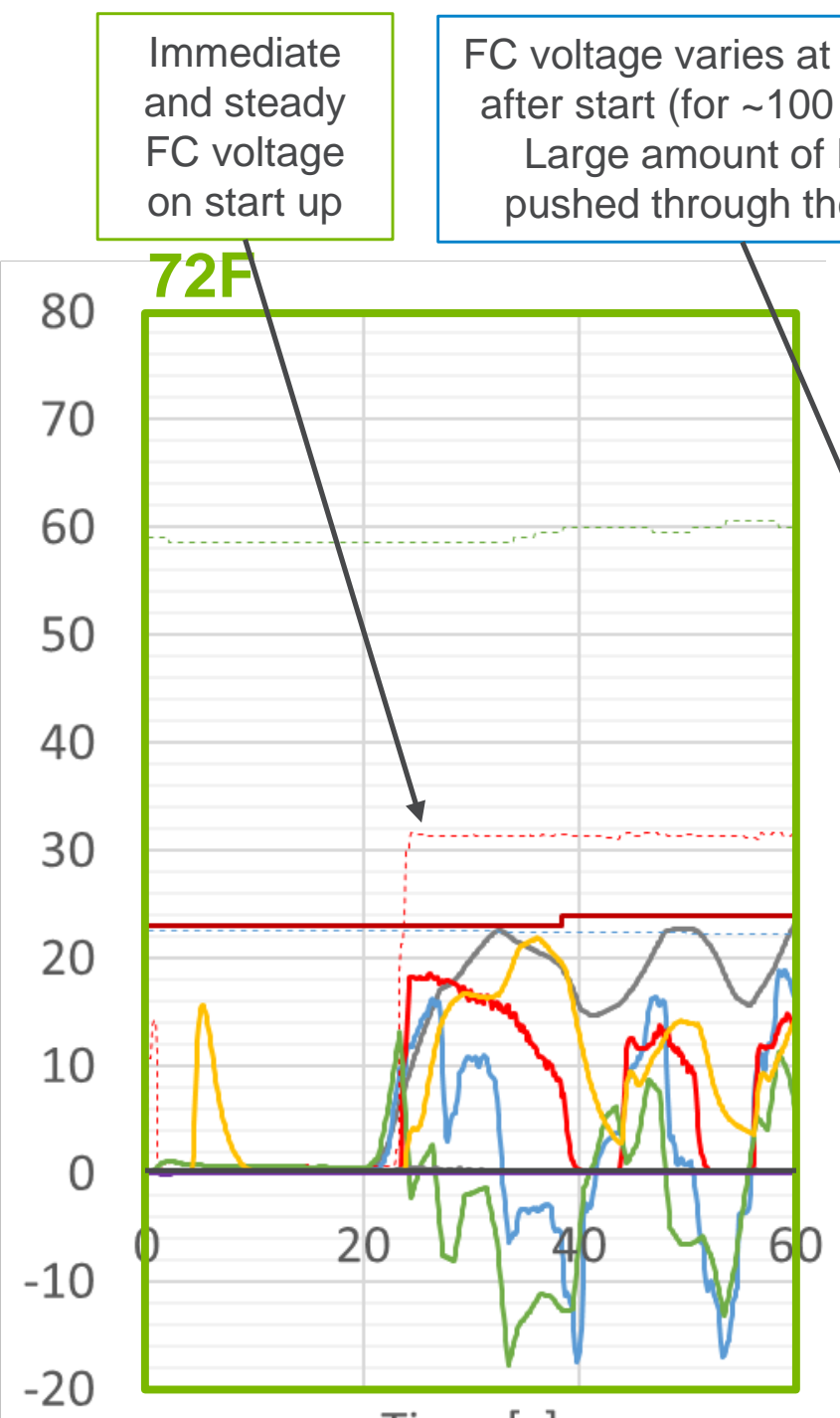

Time [s]

FC voltage low with minimal initial power output. FC

voltage does not stabilized until 150 seconds.

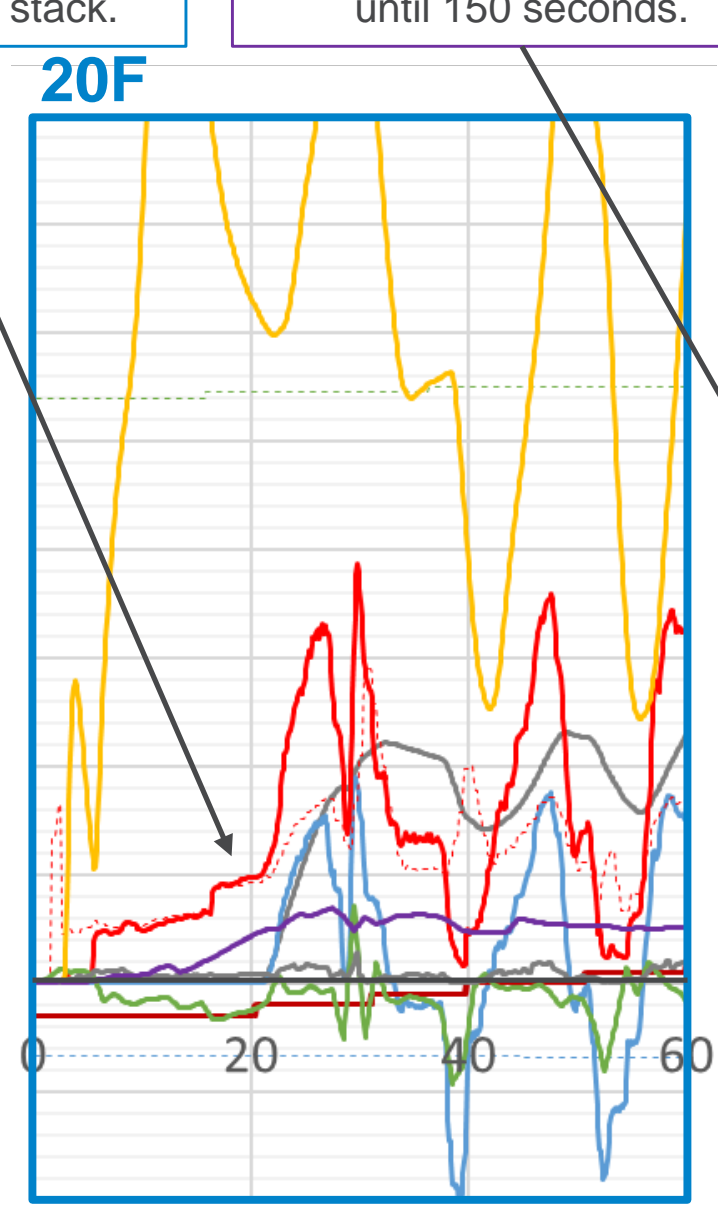

Time [s]

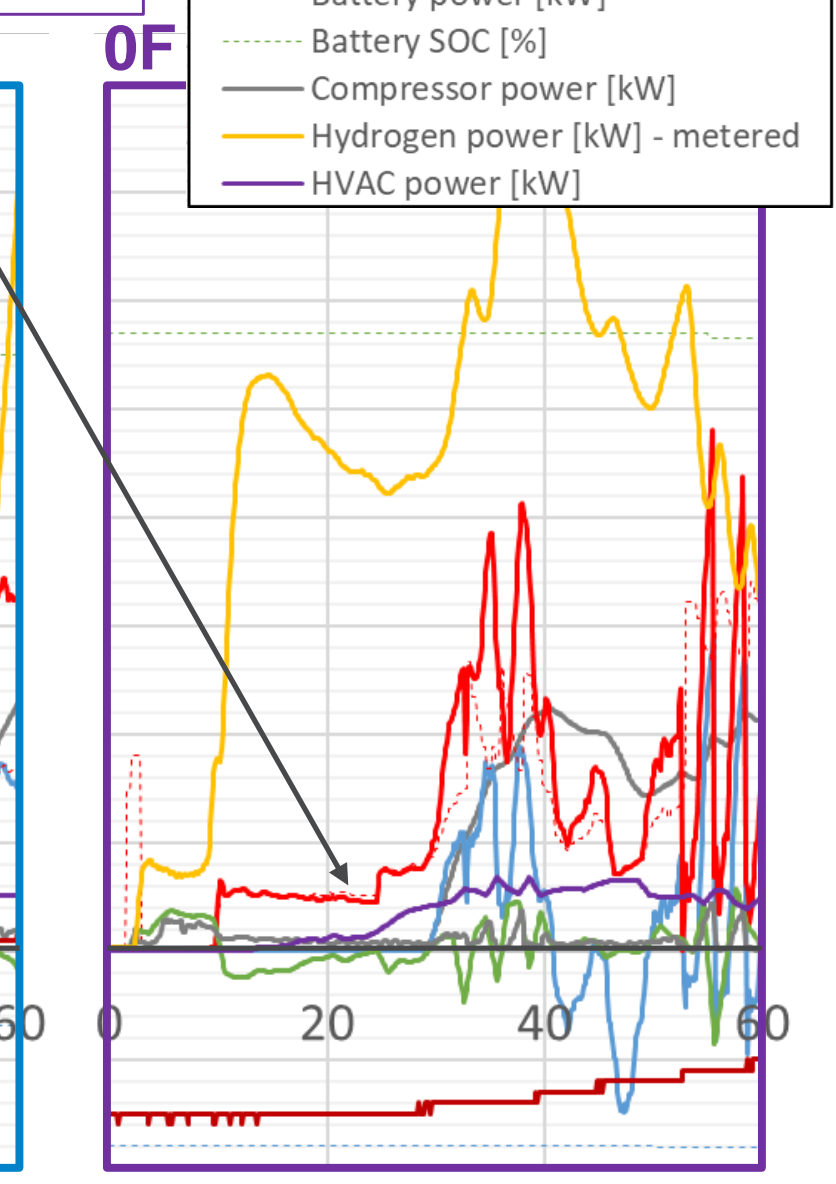

Time [s] 


\section{FUEL CELL START UP ON COLD START AT 72F}
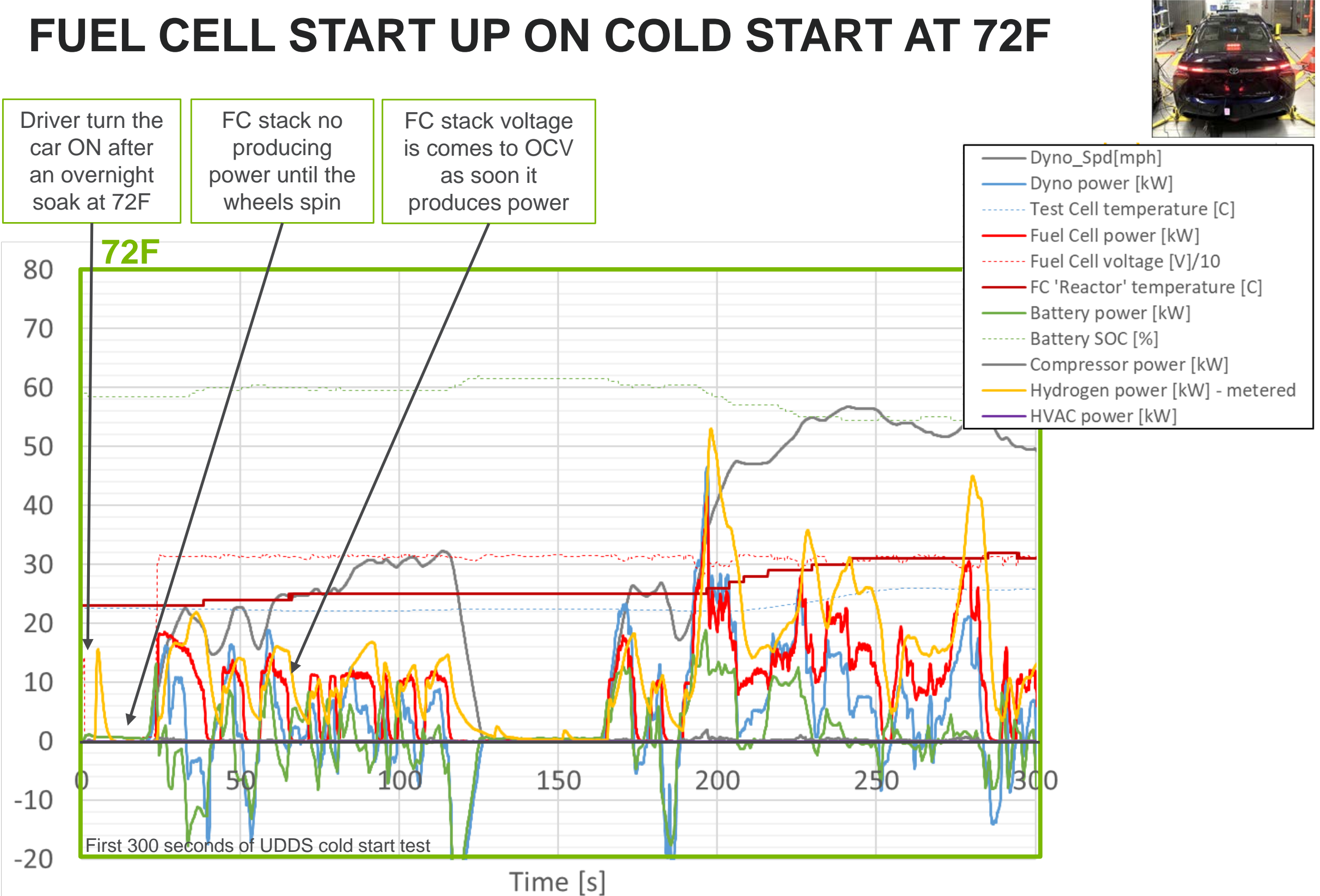


\section{FUEL CELL START UP ON COLD START AT 20F}

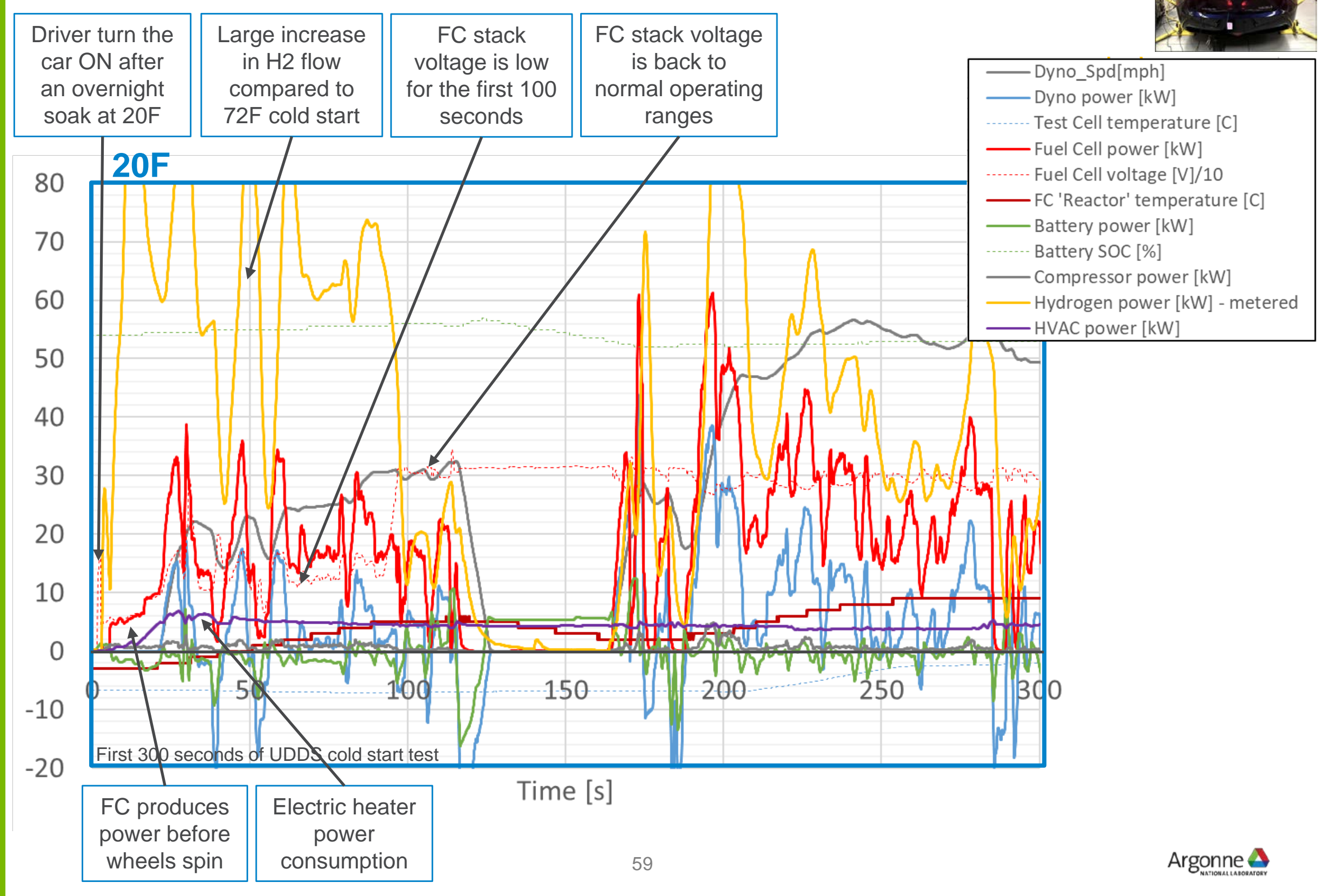




\section{FUEL CELL START UP ON COLD START AT OF}

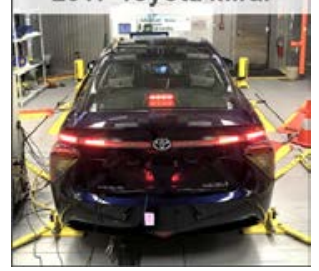

after 2+ days of $\mathrm{OF}$

temperatures. The wheel

spin after 20 seconds.

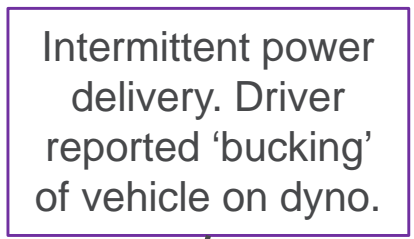

FC stack
voltage
back to
'normal'

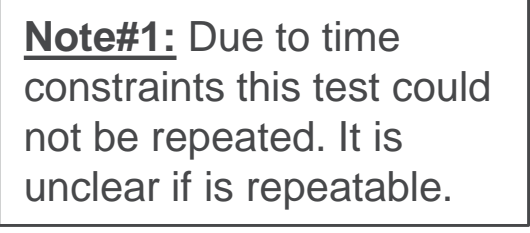

80 0F full weekend sodk (2+ days)

70

70

60

50

40

30

20

10

0

$-10$

$-20$

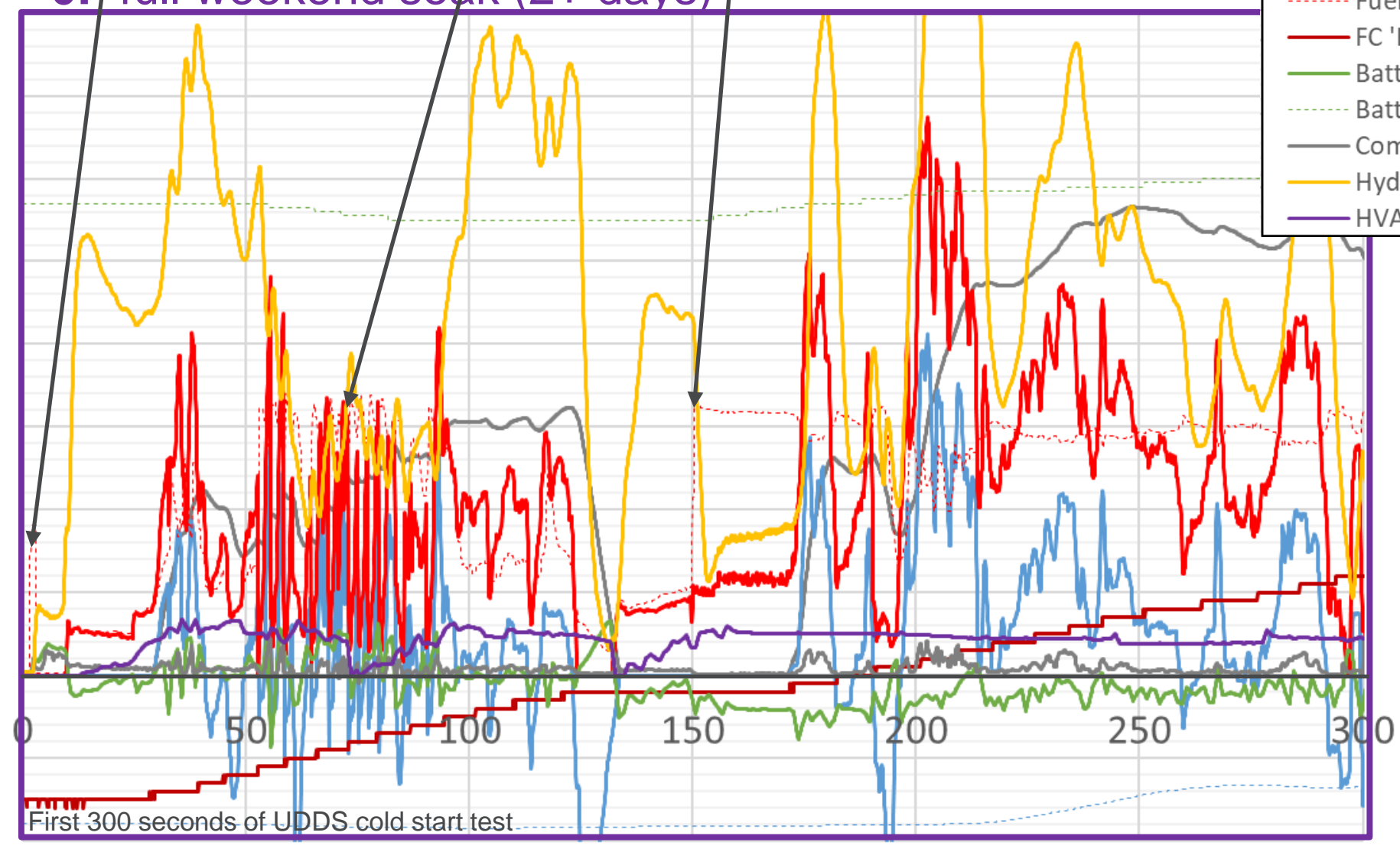

Time [s]
Note\#2: A OF cold start UDDS test which only 16 hours of soak was performed as well. No drive quality issues were reported on that test. 


\section{MAXIMUM ACCELERATION AT OF}

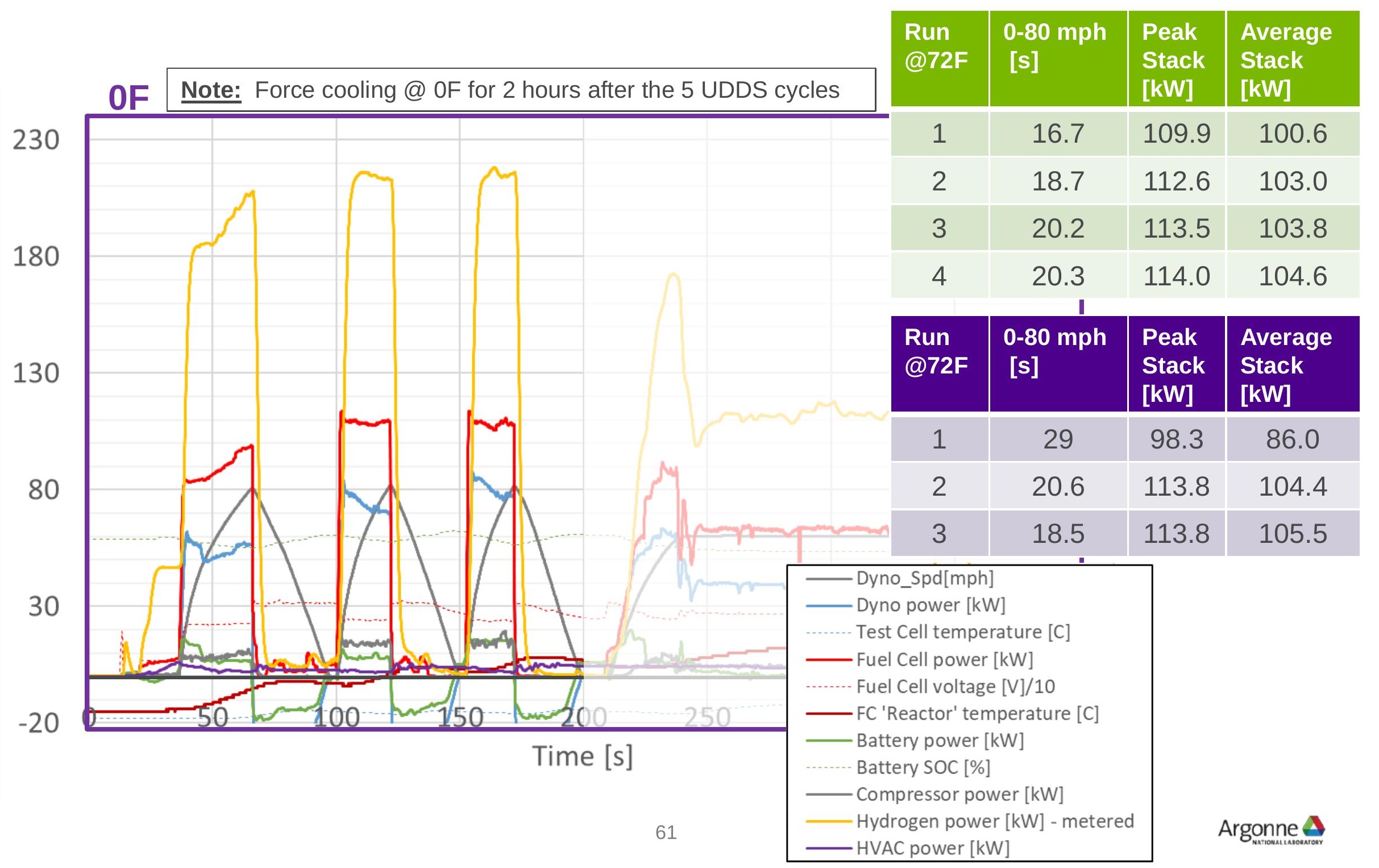




\section{HILL CLIMB WITH SOLAR LOAD}

The Mirai maintained the

62 mph speed target in these conditions
Continuous power of $63 \mathrm{~kW}$ after 30 minutes

\section{0 \\ 120 \\ 100 \\ 80 \\ 60 \\ 40 \\ 20 \\ 0}
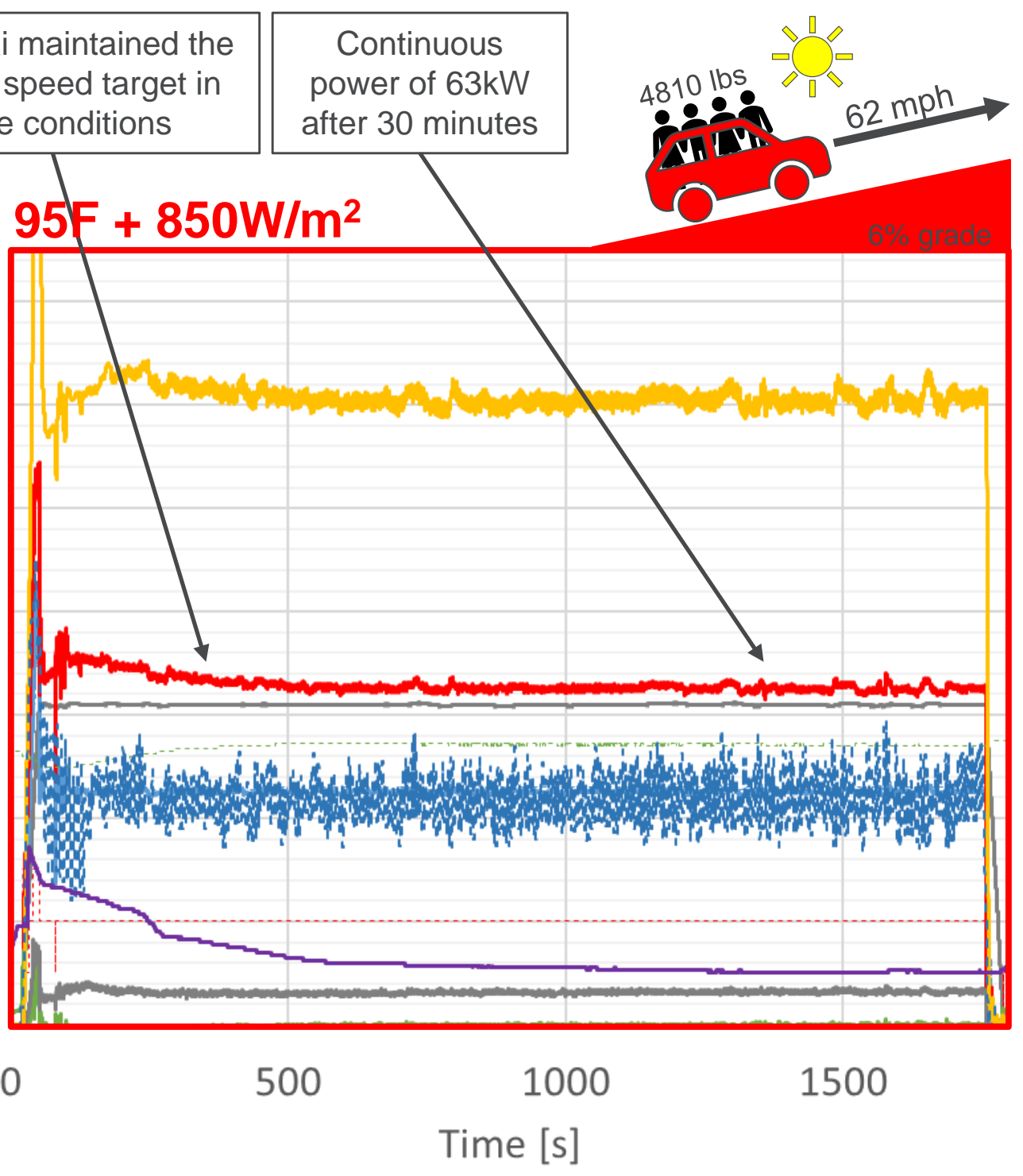

Time $[s]$
Note: This is higher continuous power compared to the $25 \%$ grade test. The vehicle speed in grade test was $27 \mathrm{mph}$. That low speed resulted in low air flow from the facility fan in front the vehicle and therefore in a lower heat rejection potential.

\begin{tabular}{|l}
\hline Dyno_Spd[mph] \\
- Dyno power [kW] \\
Accelerator pedal position [\%] \\
- Fuel Cell power [kW] \\
- Number of H2 injector [\#]x10 \\
Battery power [kW] \\
Battery Soc [\%] \\
Compressor power [kW] \\
- - - - Dydrogen power [kW] - metered \\
- HVAC compressor [kW]x10
\end{tabular}

\section{Hill Climb test}

- 62 mph (100 km/h)

- $6 \%$ grade

- At 4810 lbs test weight (GVW)

- 95F ambient temperature

- $850 \mathrm{~W} / \mathrm{m}^{2}$ solar load

- Climate control set to 72F auto

$\rightarrow$ Realistic worst case scenario 


\section{CONCLUSION AND TAKEAWAYS FROM TESTING A 2017 TOYOTA MIRAI FUEL CELL VEHICLE}
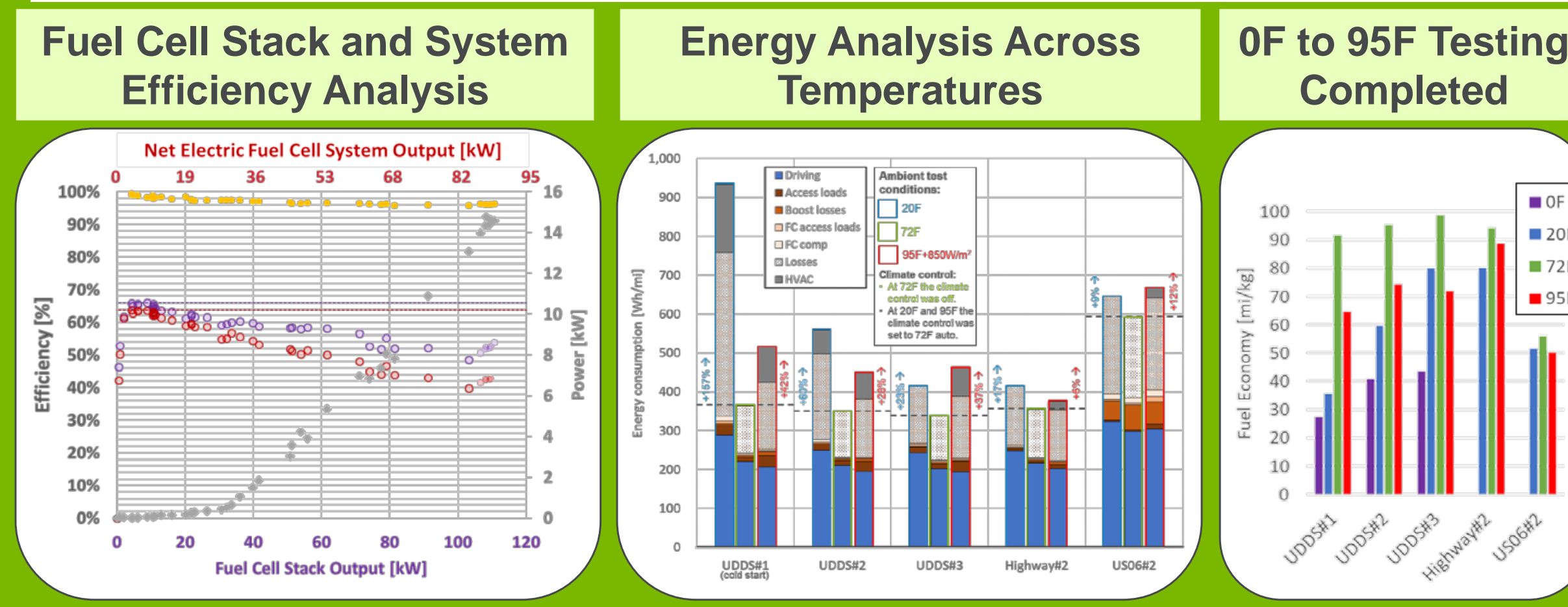

\section{Completed}

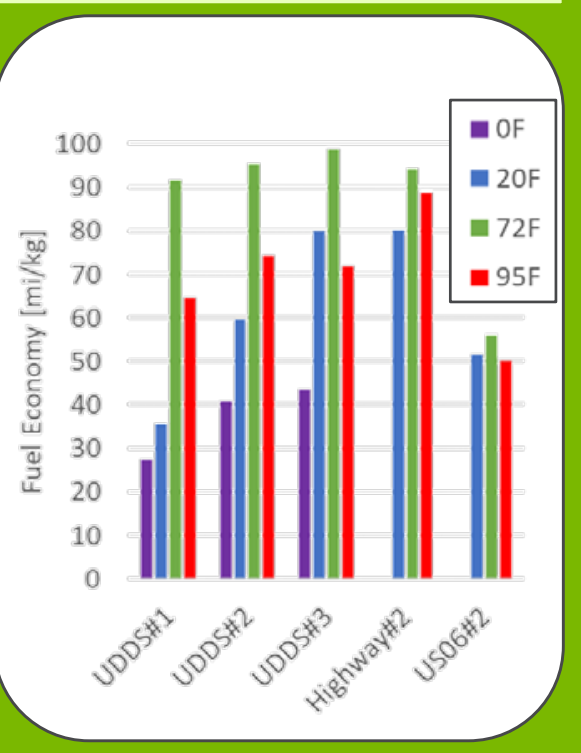

\section{Fuel Cell dominant hybrid electric vehicle.}

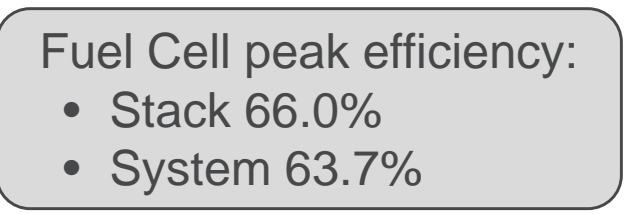
Corelated FC system parameters and operation to output.

Contrary to BEVs, FCVs have enough waste heat to keep a cabin warm.
Peak power is $110 \mathrm{~kW}$ for a limited time period. Continuous power will vary from $\sim 50 \mathrm{~kW}$ to $\sim 75 \mathrm{~kW}$ depending on thermal conditions and vehicle speed.
The FC is starved of $\mathrm{H}_{2}$ when not used. The fuel cell idle fuel flow rate is $4.39 \mathrm{~g} / \mathrm{hr}$.
Power output of the FC system conditioning to OF is limited initially
$10 \mathrm{~Hz}$ data will be available publicly at www.anl.gov/d3 Argonne $\mathbf{A}$ 
TECHNOLOGY ASSESSMENT OF A FUEL CELL VEHICLE: 2017 TOYOTA MIRAI

HENNING LOHSE-BUSCH, MICHAEL DUOBA, KEVIN STUTENBERG, SIMEON ILIEV, MIKE KERN

Argonne National Laboratory

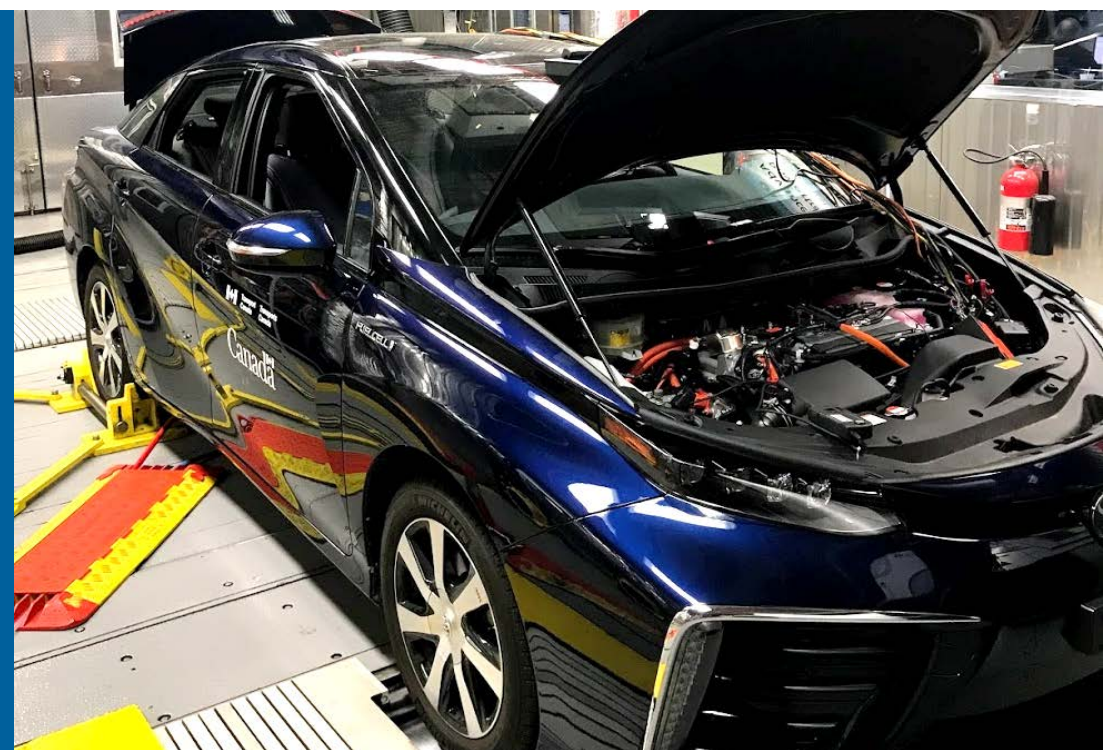

BRAD RICHARDS, MARTHA CHRISTENSON Transport Canada AARON LOISELLE-LAPOINTE Environment and Climate Change Canada 


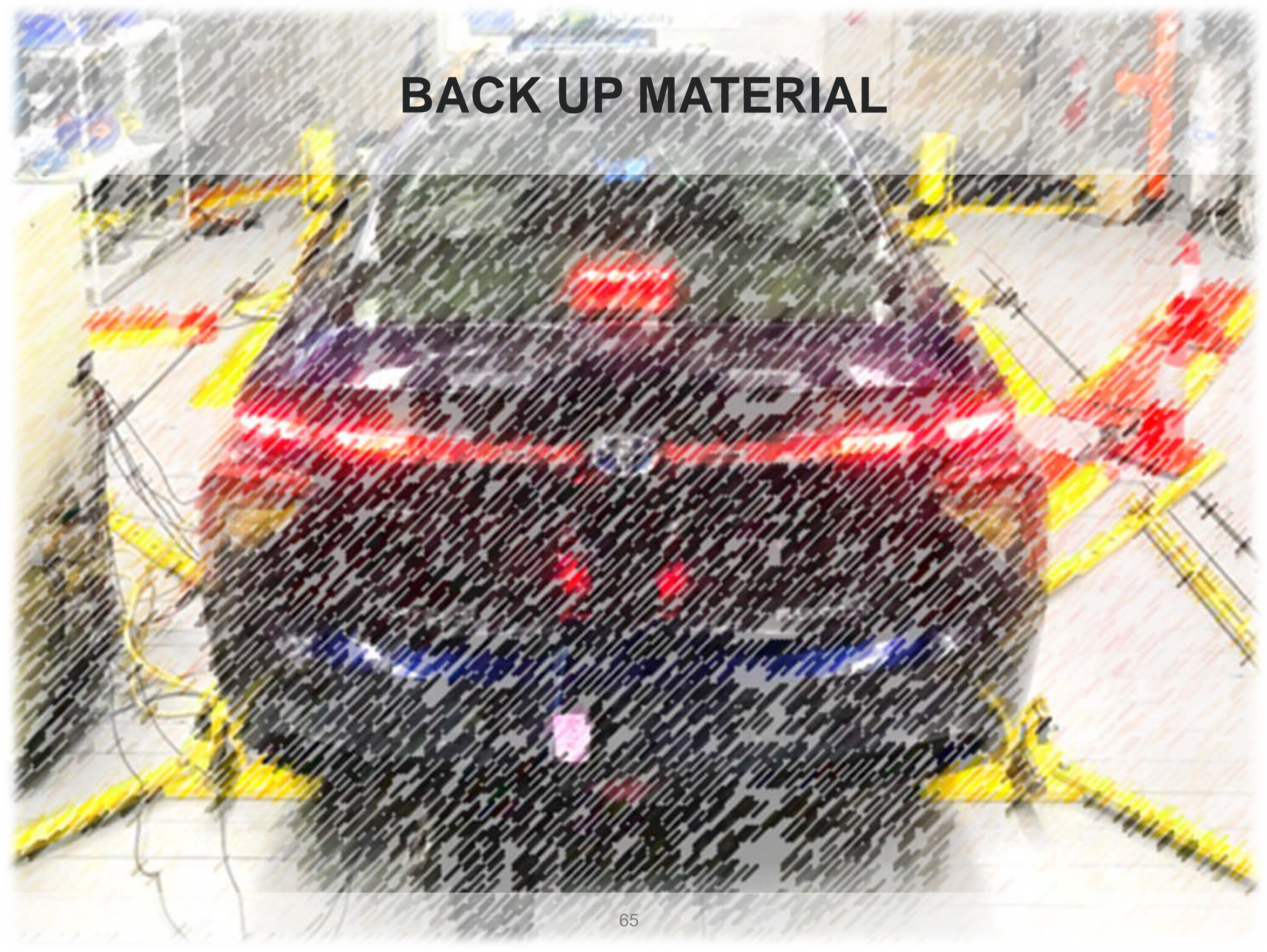



4WD Chassis Dynamometer Thermal Test Cell

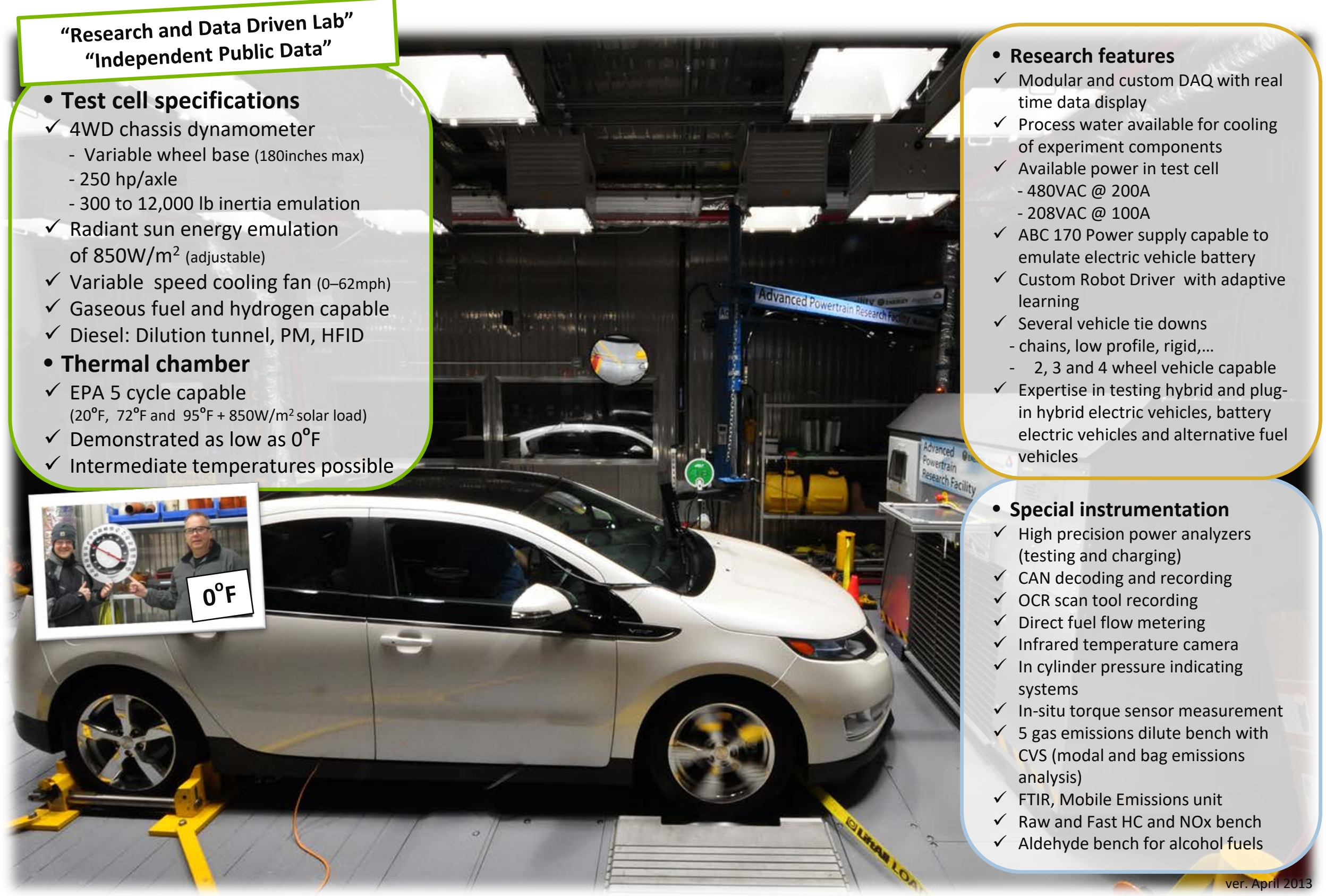




\section{HOW ARE VEHICLES TESTED FOR ENERGY CONSUMPTION}

Chassis dynamometer test cell

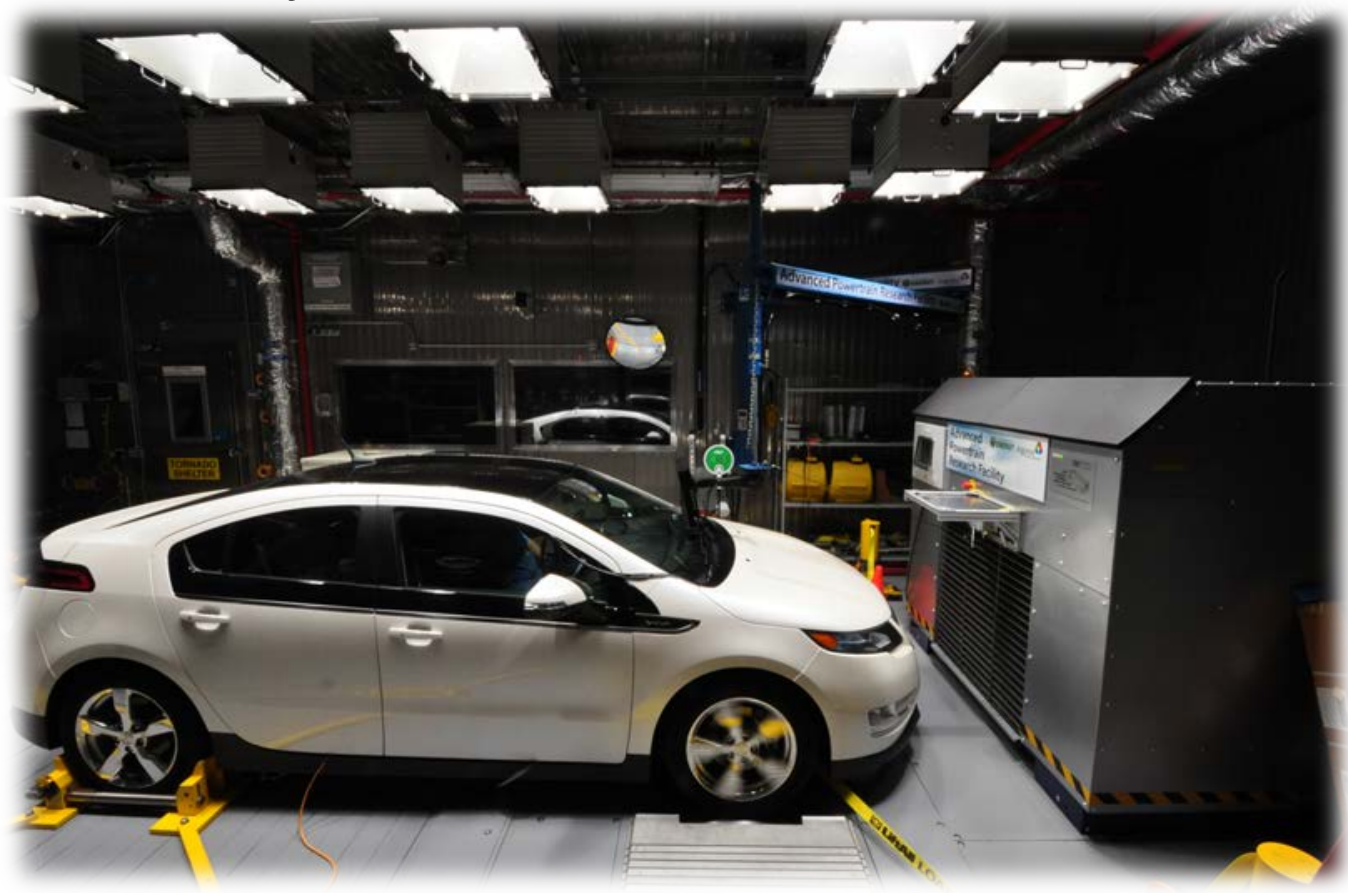

Simple physics are used to emulate the proper load at the wheel to emulate the real world

$$
\begin{aligned}
& \begin{array}{l}
\text { Power }_{\text {propulsion }}=(\underbrace{\left.m \times \frac{\partial(V)}{\partial t}\right)}_{\begin{array}{l}
\text { Inertia force: } \\
\text { overcome change }
\end{array}}+F_{\text {roadload }}) \times V \\
\begin{array}{l}
\text { Road load force: } \\
\text { caused by wind r }
\end{array}
\end{array} \\
& \text { in momentum }
\end{aligned}
$$

A driver accelerates and brakes to follow a drive trace

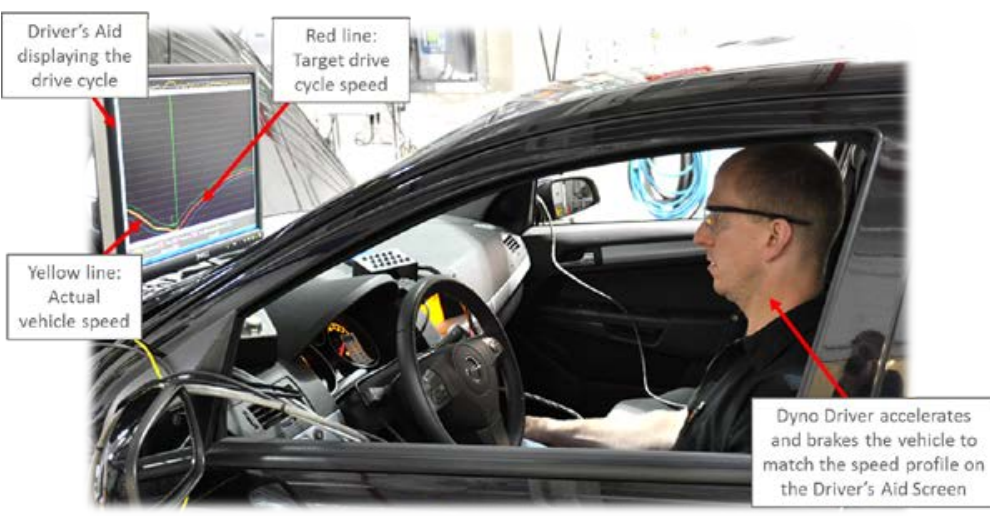

A drive trace is a defined speed profile as a function of time
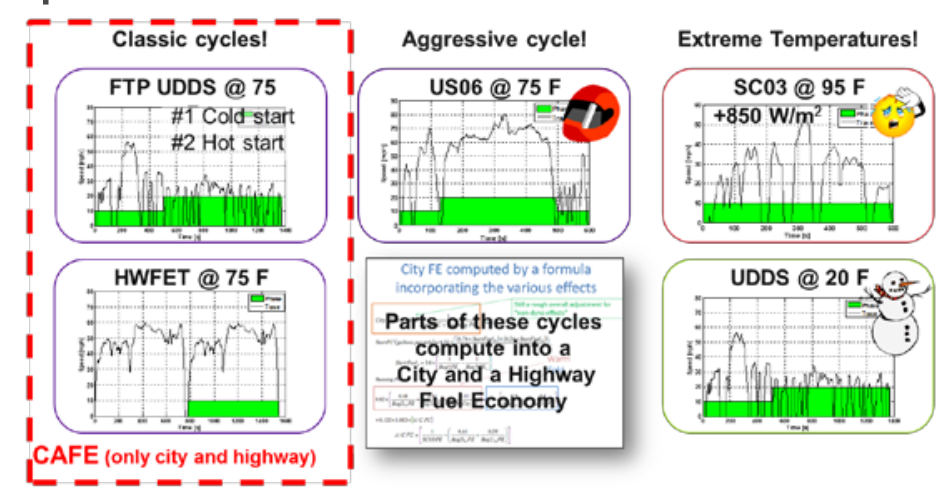


\section{EPA'S 5 CYCLES TESTS FOR FUEL ECONOMY LABEL}

EPA implemented the new 5 Cycle Fuel Economy Label to close the gap to real world fuel economy the consumer can expect
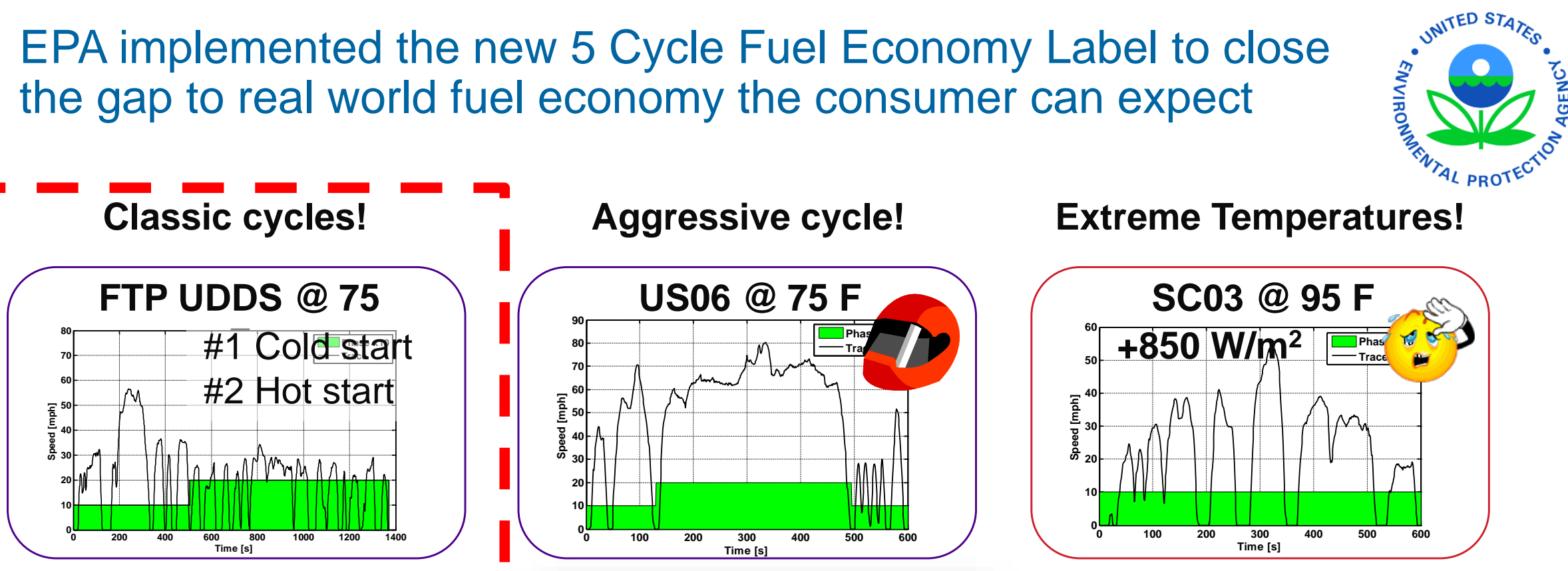

Extreme Temperatures!

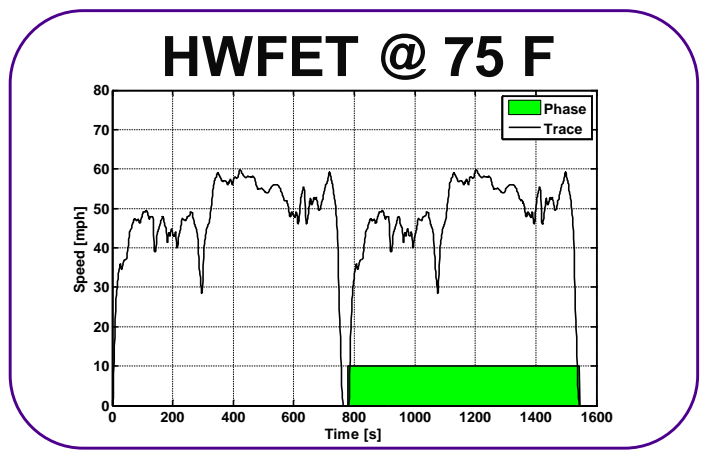

CAFE (only city and highway)

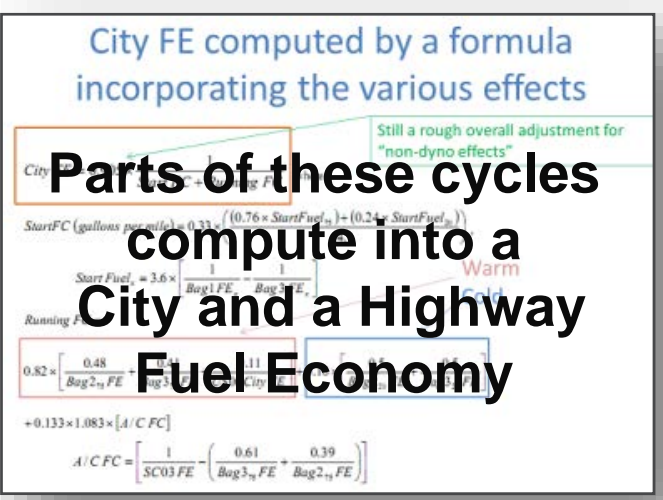

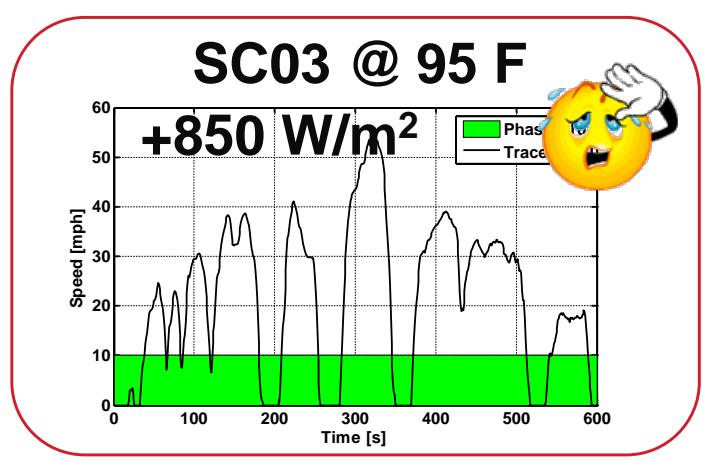

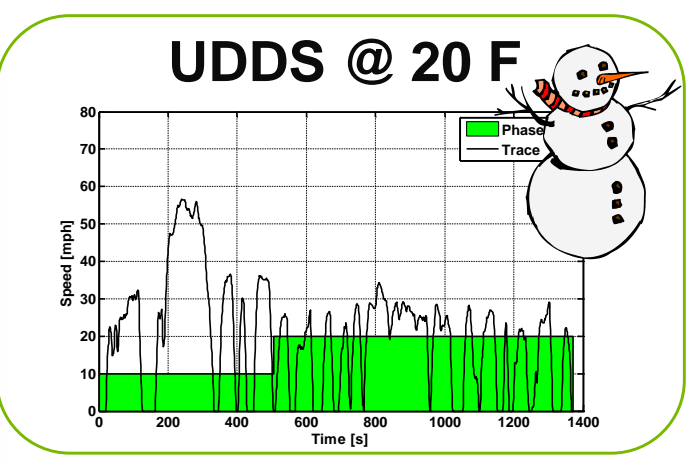




\section{PSYCHOLOGY OF FUEL ECONOMY VS. FUEL CONSUMPTION}

\section{Fuel Economy = Distance / Fuel}

If little fuel is used, FE 'explodes' to a large number and becomes misleading
Fuel consumption= Fuel / Distance

$\mathrm{FC}$ is a better scale for very efficient vehicles!

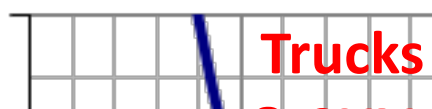

\&. SUVS

\section{'The MPG illusion'}
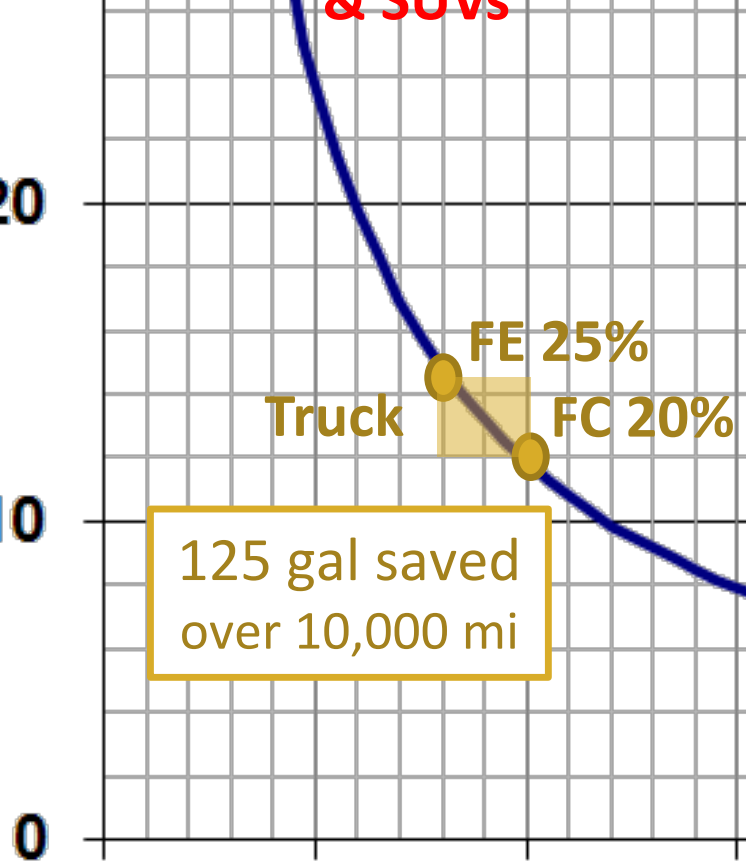

84 gal saved over $10,000 \mathrm{mi}$

\section{5 gal saved} over 10,000 mi

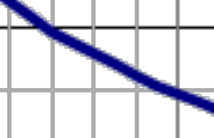

FE $50 \%$

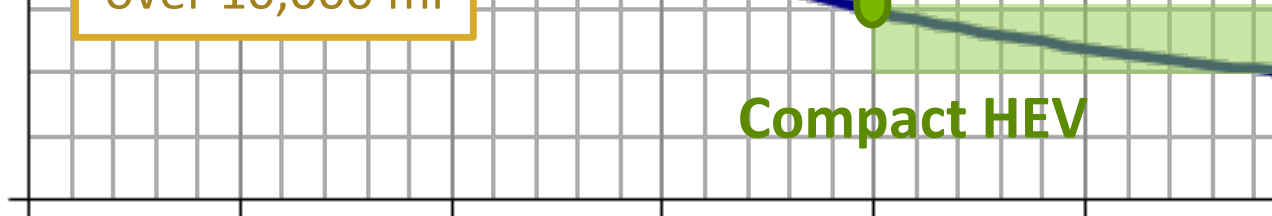

010

20

30

40

50

60

FC $33 \%$

Plug-in Hybrid Electric Vehicle Fuel economy [mpg] 


\section{ELECTRIFICATION COMPLICATES EFFICIENCY \\ CALCULATIONS}

Conventional Vehicle

2012 Focus 2L

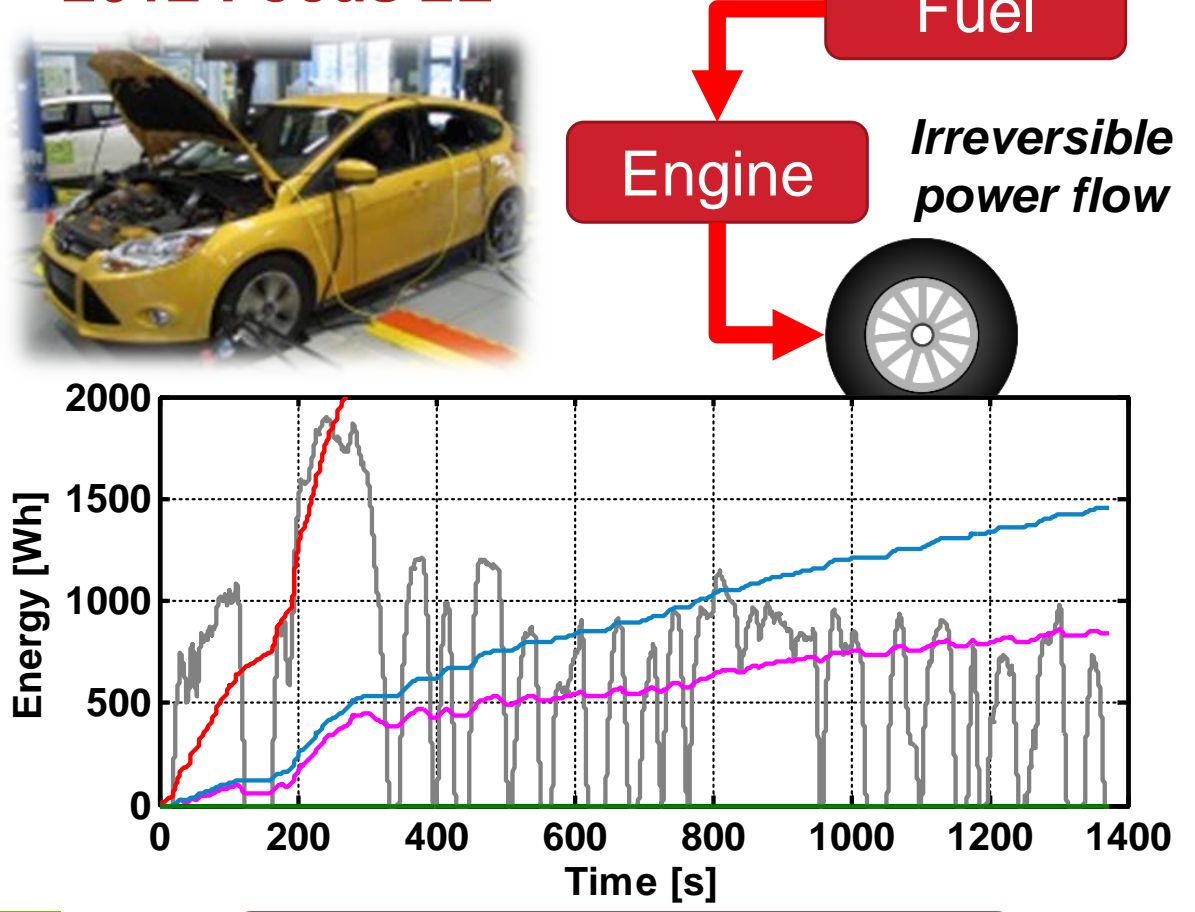

$$
\text { Efficiency }=\frac{\text { Energy }_{\text {out }}}{\text { Energy }_{\text {in }}}
$$

\section{Electric Vehicle}

2013 Focus BEV

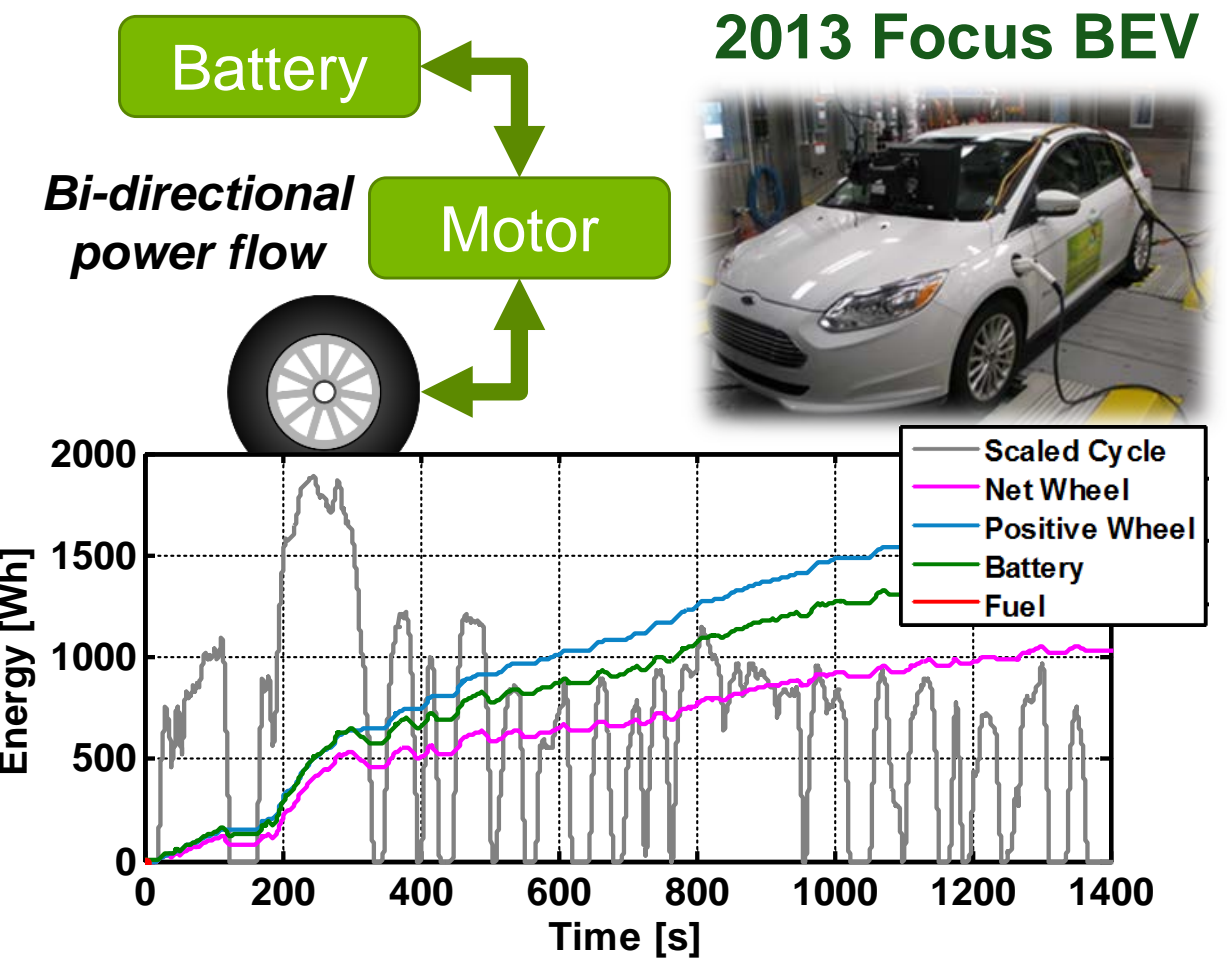

Regenerative braking reverses the power flow and charges the high voltage battery (In \& Out reverse)

$\rightarrow$ SAE J2951 defines "Cycle Energy" as the integration of positive power at the wheel over the cycle (regenerative braking = "free" energy) 


\section{HIGHER EFFICIENCY POWERTRAINS ARE MORE SENSITIVE}

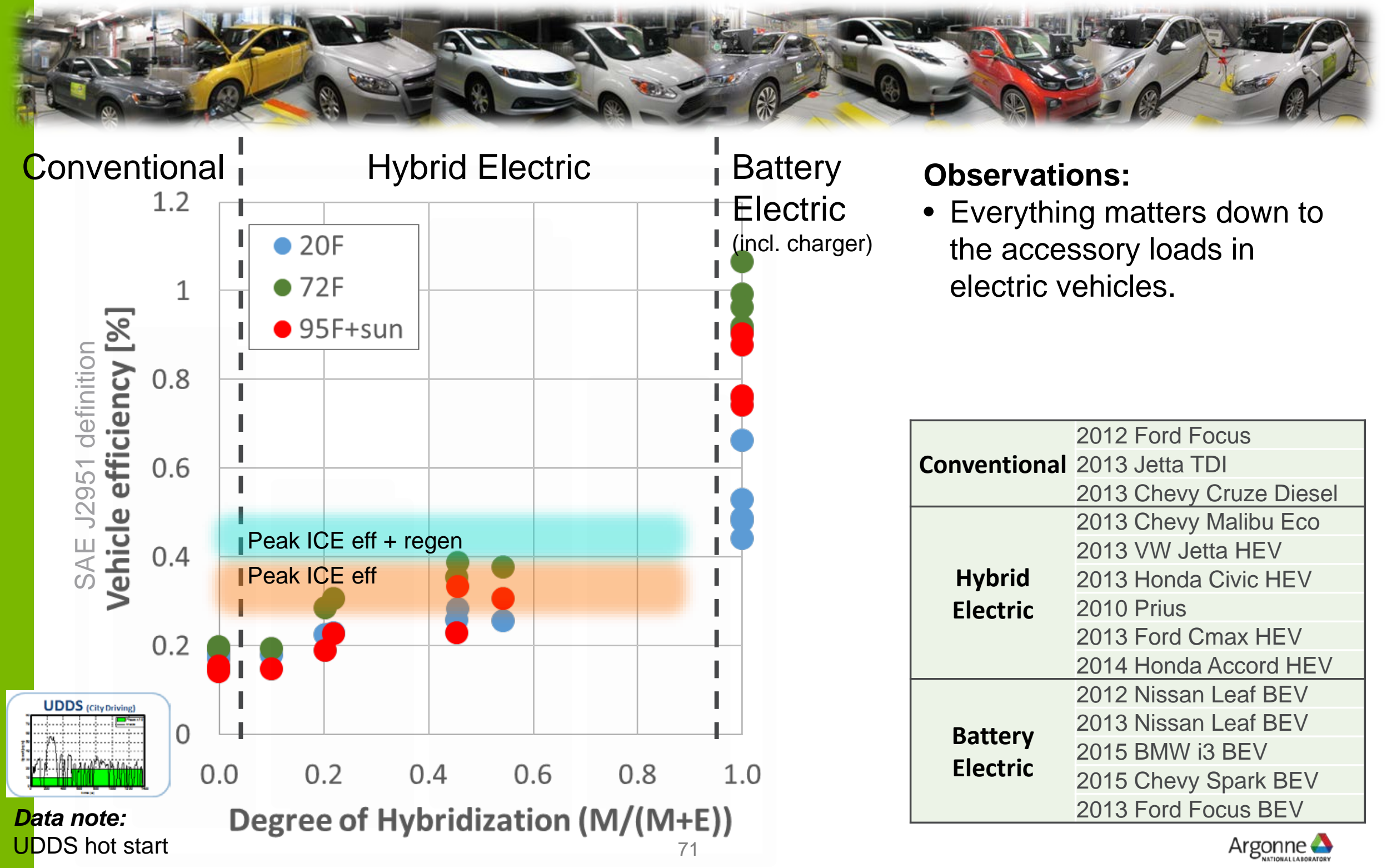




\section{NET ENERGY CHANGE OF THE BATTERY DETERMINES IF A HEV IS CHARGE SUSTAINING OVER THE TEST CYCLE}

- Net energy change (NEC) = net battery energy delta over the test cycle

- A test is considered charge sustaining when the NEC of battery is less then $1 \%$ of fuel energy used over the test cycle

- If an HEV discharges it's battery over a test cycle, the fuel consumption will be increased.
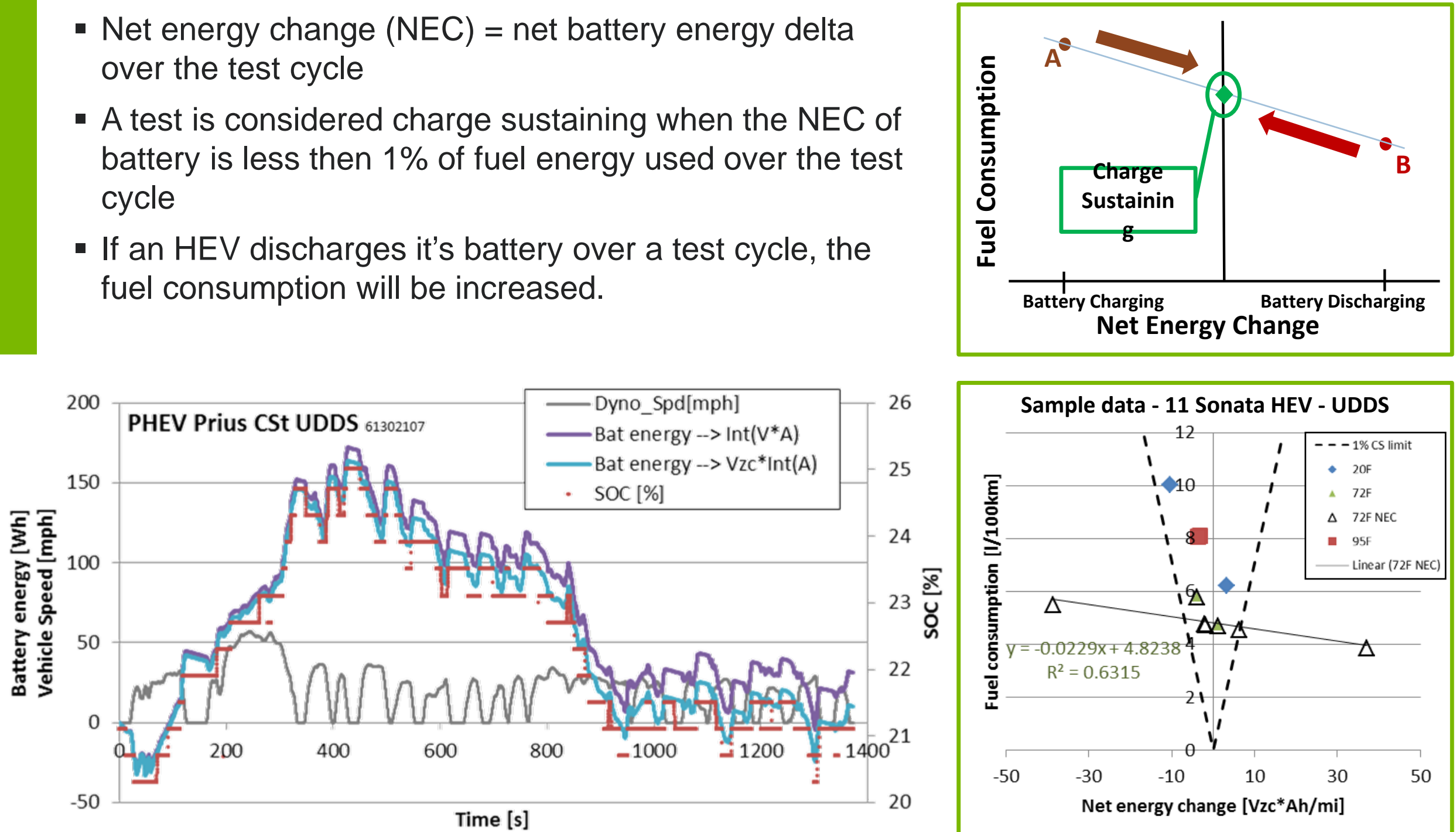


\section{SAFETY AND METERING PANEL}

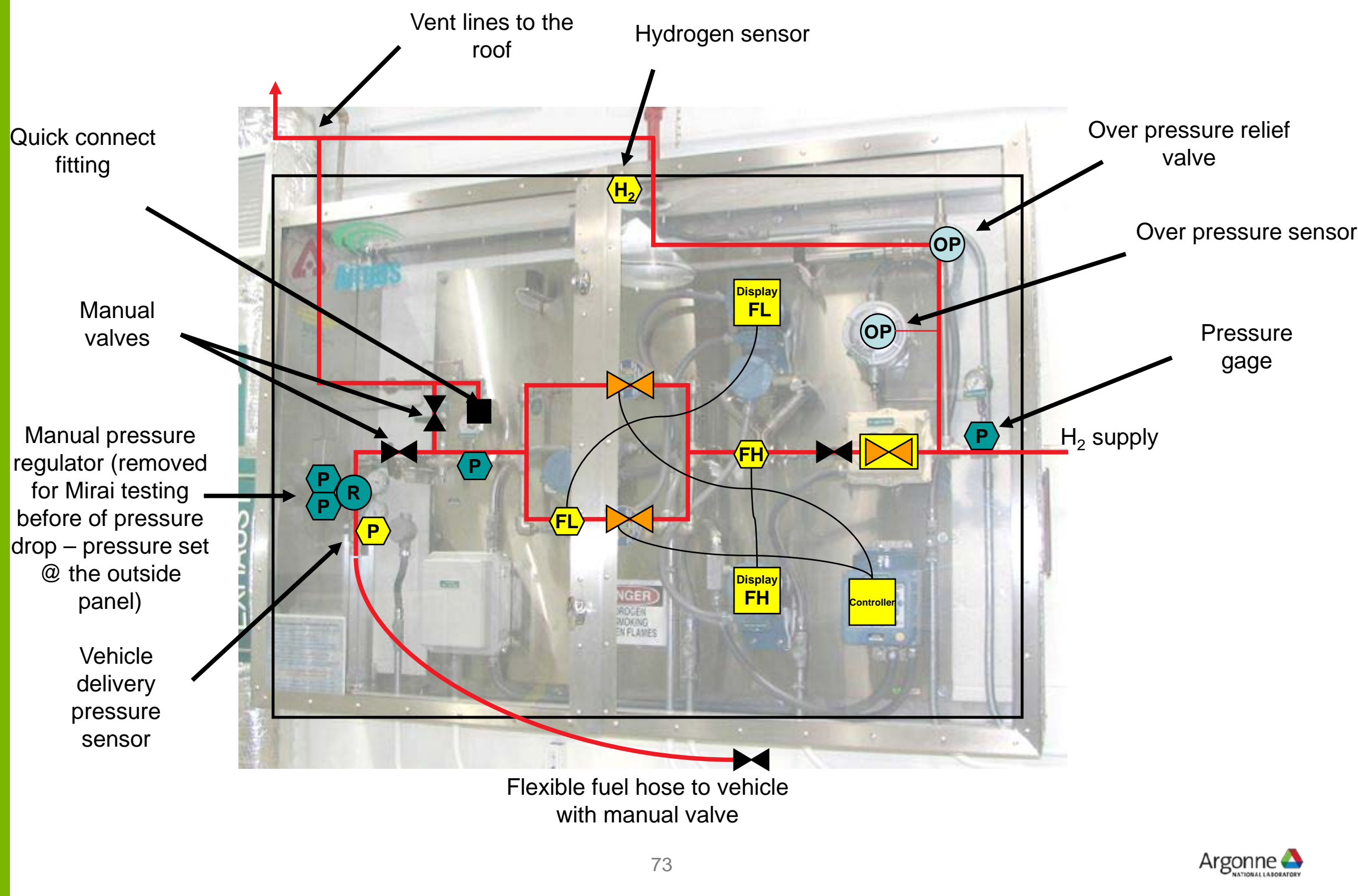




\section{BOOST CONVERTER OPERATION}

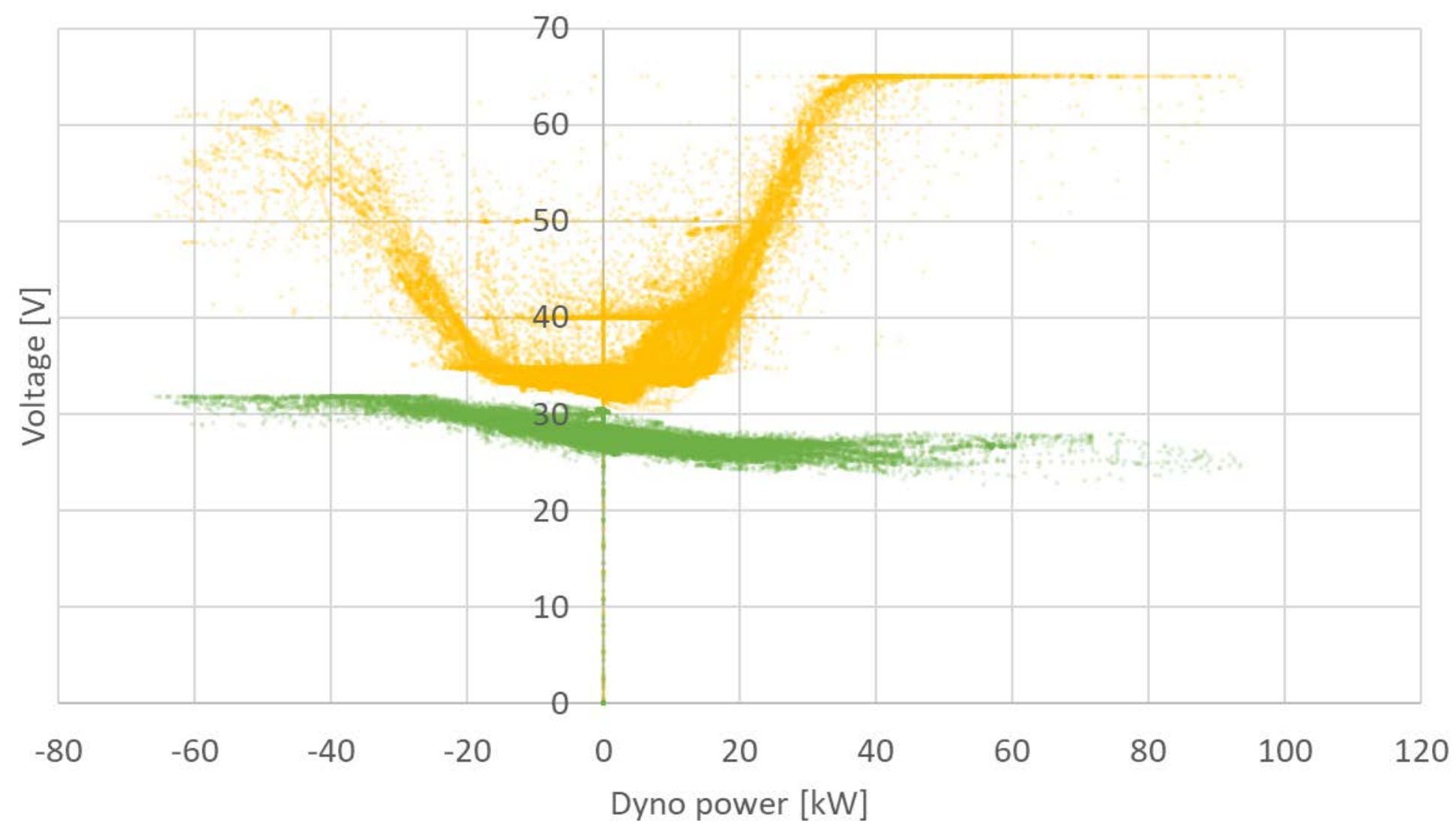

Boosted voltage [V] Battery Voltage [V] 


\section{RIPPLE AND PULSES IN STEADY OPERATION}

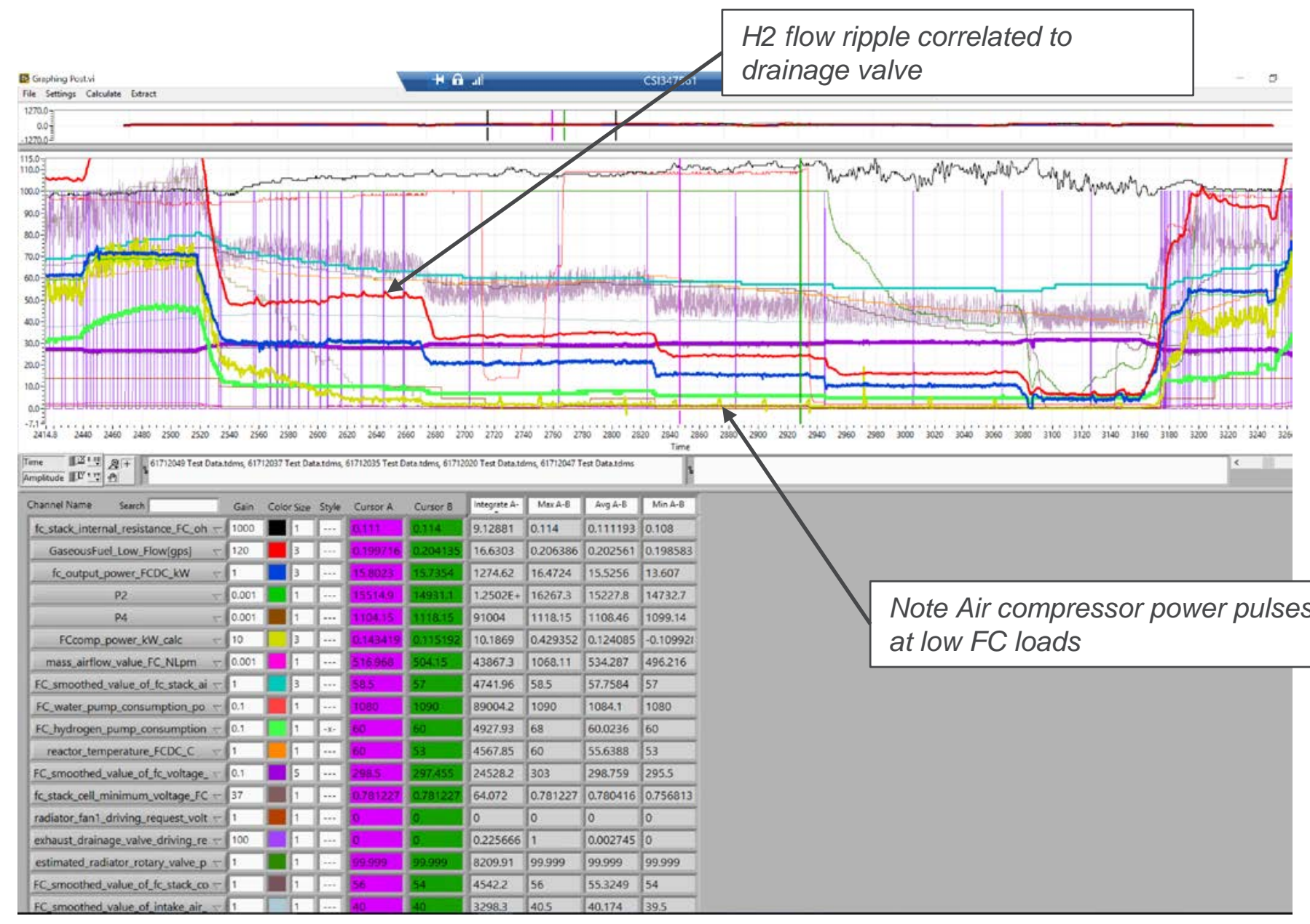




\section{SSS @ 72F 15, 30, 45, 60, 75 MPH}

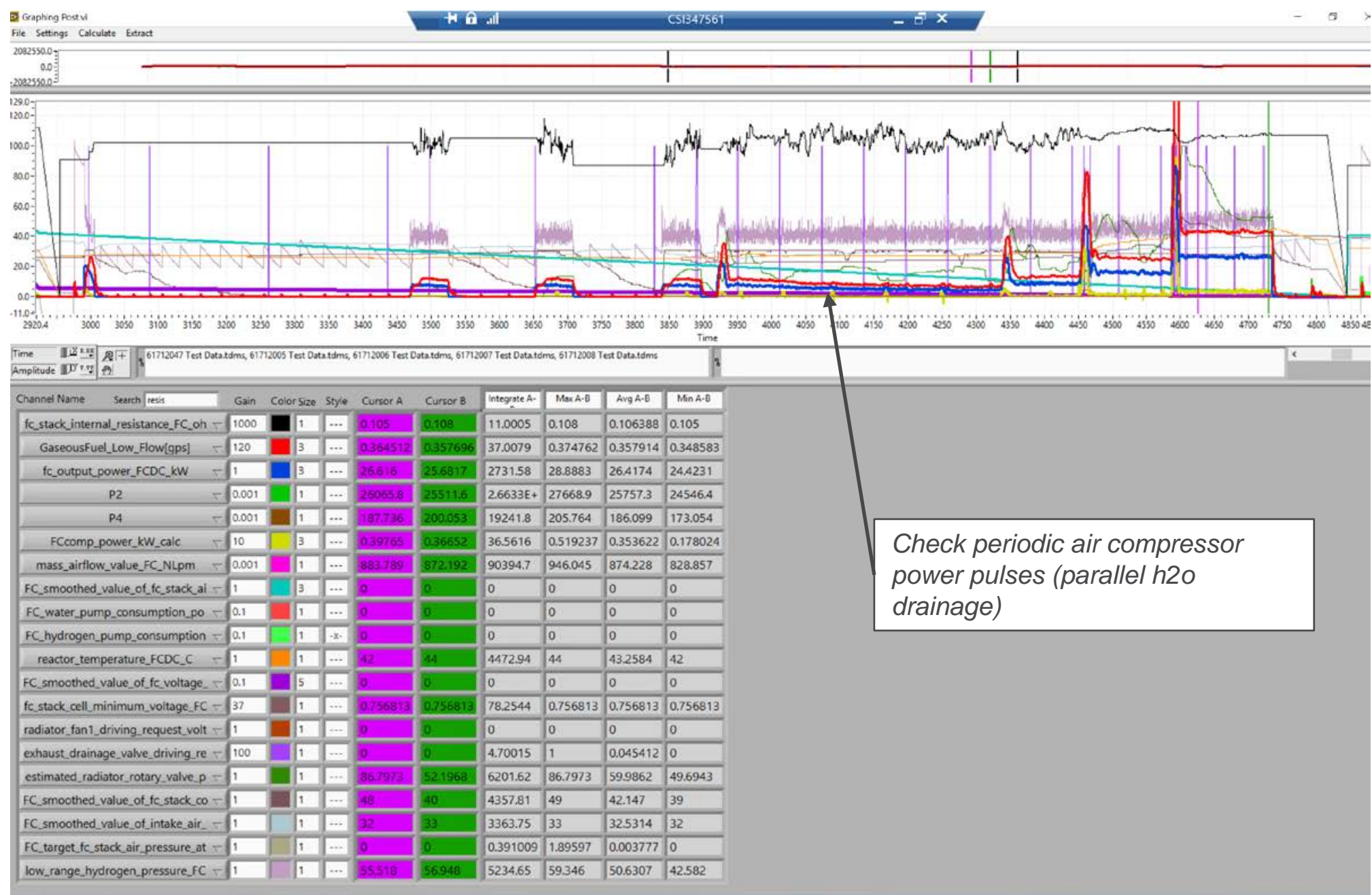




\section{5\% GRADE @ 95F WITH 850 W/M²}

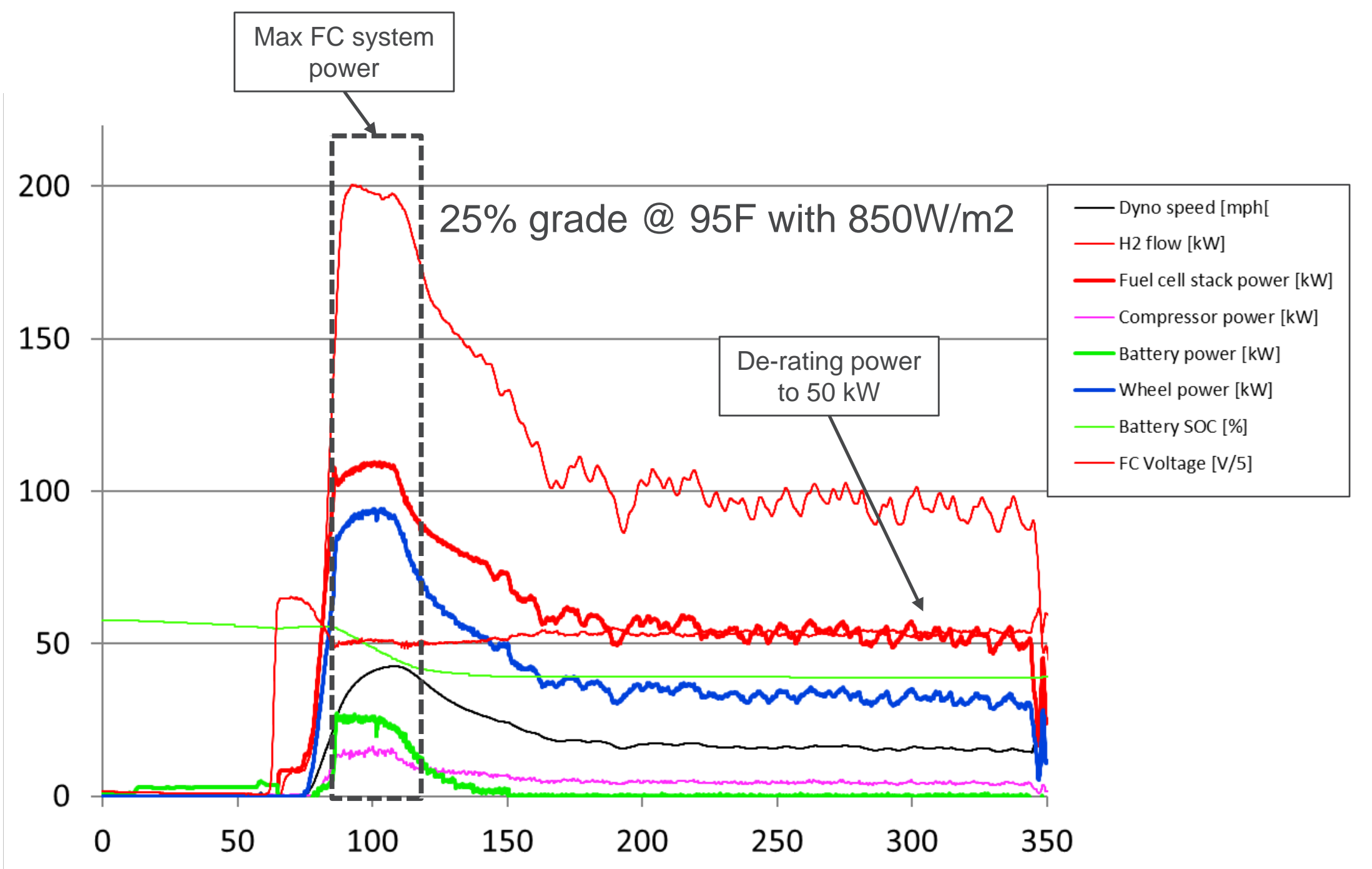




\section{Argonne}

\section{Energy Systems Division}

Argonne National Laboratory

9700 South Cass Avenue, Bldg. 362

Argonne, IL 60439

wWw.anl.gov 